\title{
OXYGEN ISOTOPES IN FORAMINIFERA: OVERVIEW AND HISTORICAL REVIEW
}

\author{
PAUL N. PEARSON
}

School of Earth and Ocean Sciences, Main Building, Cardiff University, Park Place, Cardiff, CF10 3AT, United Kingdom pearsonp@cardiff.ac.uk

\begin{abstract}
Foraminiferal tests are a common component of many marine sediments. The oxygen isotope ratio $\left(\delta^{18} \mathrm{O}\right)$ of test calcite is frequently used to reconstruct aspects of their life environment. The $\delta^{18} \mathrm{O}$ depends mainly on the isotope ratio of the water it is precipitated from, the temperature of calcification, and, to a lesser extent, the carbonate ion concentration. Foraminifera and other organisms can potentially preserve their original isotope ratio for many millions of years, although diagenetic processes can alter the ratios. Work on oxygen isotope ratios of foraminifera was instrumental in the discovery of the orbital theory of the ice ages and continues to be widely used in the study of rapid climate change. Compilations of deep sea benthic foraminifer oxygen isotopes have revealed the long history of global climate change over the past 100 million years. Planktonic foraminifer oxygen isotopes are used to investigate the history of past sea surface temperatures, revealing the extent of past 'greenhouse' warming and global sea surface temperatures.
\end{abstract}

\section{INTRODUCTION}

THE MEASUREMENT of oxygen isotope ratios of biogenic calcite is one of the longestestablished and most widely used of all paleoclimate proxies. It principally provides information on the temperature or oxygen isotope ratio of seawater at the time of calcification if the other parameter is known or assumed. The signal can, in principle, survive for hundreds of millions of years in fossils. Although many types of organisms produce calcite skeletons, foraminifera have been employed particularly widely because of their abundance and diversity in marine sediment, especially deep-sea oozes where many of the longest and most continuous paleoclimate records are found. Here, the development of the proxy in both benthic and planktonic foraminifera is reviewed in two parts. Part 1 is an overview of the principles of the technique and its early development, together with some of its complications and limitations. Part 2 outlines some of the major applications in paleoclimate studies from the 1970s to the present.

\section{PART 1: PRINCIPLES AND HISTORY}

\section{Oxygen isotopes}

Note: A number of textbooks provide succinct accounts of oxygen isotope systematics and measurement; this section is based mainly on Faure and Mensing (2005), Allègre (2008), and Hoefs (2009).

Oxygen has three stable isotopes, ${ }^{16} \mathrm{O},{ }^{17} \mathrm{O}$, and ${ }^{18} \mathrm{O}$, which occur on Earth in the approximate proportions $99.757 \%, 0.038 \%$, and $0.205 \%$, respectively (Rosman and Taylor, 1998; other sources give slightly different figures). These different abundances reflect the fact that the three isotopes are produced by different synthetic pathways in stars. The proportions vary somewhat in natural Earth materials because each substance has its own prior history of fractionation (processes that sorted or partitioned the isotopes) and mixing (processes that combined or assimilated the isotopes). Fractionations occur in two main ways, isotope-exchange reactions and kinetic effects. Because molecules with a heavy isotope have slightly greater covalent bond strengths and lower vibrational frequencies than their lighter counterparts, they are slightly less reactive. They are also slower to diffuse along concentration gradients and across membranes. Examples of fractionation processes that affect oxygen isotopes in water are evaporation, in which the light isotope ${ }^{16} \mathrm{O}$ is slightly preferred, and condensation,

In Reconstructing Earth's Deep-Time Climate-The State of the Art in 2012, Paleontological Society Short Course, November 3, 2012. The Paleontological Society Papers, Volume 18, Linda C. Ivany and Brian T. Huber (eds.), pp. 1-38. Copyright (C) 2012 The Paleontological Society. 
where the heavy isotope ${ }^{18} \mathrm{O}$ is slightly preferred. The physical mixing of two water masses with different isotopic ratios (e.g. when a river flows into the sea) will produce water with an intermediate ratio.

Because most natural fractionation and mixing processes are strictly mass dependent, the isotopes ${ }^{17} \mathrm{O}$ and ${ }^{18} \mathrm{O}$ fractionate and combine relative to ${ }^{16} \mathrm{O}$ proportionally according to their respective masses $\left({ }^{18} \mathrm{O}\right.$ fractionating twice as much as ${ }^{17} \mathrm{O}$ ), so for most applications, there is little to be gained by measuring both isotopes. The normal procedure is to measure the ratio of ${ }^{18} \mathrm{O}$ to ${ }^{16} \mathrm{O}$ in a sample. By convention, the isotope ratio, $R$, is defined as the abundance of the heavier isotope over the abundance of the lighter isotope. For the global average proportions given above, this is expressed as follows:

$$
R=\frac{{ }^{18} \mathrm{O}}{{ }^{16} \mathrm{O}}=\frac{0.205}{99.757}=0.002055
$$

Because natural fractionations are, in practice, quite small, and ${ }^{18} \mathrm{O}$ is always very much rarer than ${ }^{16} \mathrm{O}$, the isotopic ratios of natural materials are generally quite close to this average value. Small differences between small numbers are unwieldy, so (as is the convention for other stable isotope systems) oxygen isotope ratios are generally quoted as deviations (delta values) from the oxygen isotope ratio $\left(\delta^{18} \mathrm{O}\right)$ of a standard substance in parts per thousand ('per mil', sometimes 'per mille', signified by the symbol, '\%o').

$$
\delta^{18} \mathrm{O}=\left(\frac{R_{\text {sample }}-R_{\text {standard }}}{R_{\text {standard }}}\right) \times 1000
$$

There are also good, practical reasons for this convention because isotope ratios of sample materials are almost always measured relative to a laboratory standard rather than as an absolute ratio, which is much more difficult to determine accurately. Note that if a sample has a positive $\delta^{18} \mathrm{O}$, it is said to be enriched in the heavy isotope relative to the standard and, if negative, it is said to be depleted.

It so happens that two different standard values are in widespread use from which these deltavalues are quoted: Vienna Standard Mean Ocean Water (VSMOW) and Vienna Pee Dee Belemnite (VPDB, which is a carbonate standard; the his- torical reason for the adoption of this is described below). The original standards were simply SMOW and PDB, but because original supplies of both standards ran out and some inter-laboratory differences emerged in defining what the precise values were relative to other available reference materials, a worldwide convention was determined (at a meeting in Vienna) (Gonfiantini, 1984; see Coplen, 1994, for further discussion). Deviations from VSMOW tend to be used in studies of the hydrological cycle and also for hightemperature processes, such as in metamorphic rocks, and studies of phosphates and silica. Deviations from VPDB tend to be used in studies of low-temperature carbonates, including foraminifera. Note that carbon isotope ratios in carbonates, ${ }^{13} \mathrm{C} /{ }^{12} \mathrm{C}$, are also quoted relative to the same VPBD standard (as $\delta^{13} \mathrm{C} \%$ ).

The oxygen isotope ratios of carbonate samples are usually measured using a gas source mass spectrometer. The sample is reacted with $100 \%$ phosphoric acid, producing $\mathrm{CO}_{2}$ gas that is ionized in a vacuum chamber by electron bombardment. The mass spectrometer accelerates the ions under high voltage, and a magnetic field splits them into streams of different isotope ratio that generate electrical currents in the detectors. The ratio of these currents is proportional to the isotope ratio of the sample. By alternately switching between a standard of known isotope ratio (generally a $\mathrm{CO}_{2}$ reference gas supplied by the National Institute of Standards and Technology) and an unknown sample, the isotope ratio of the unknown can be calculated. In this way, the following masses are usually measured: ${ }^{12} \mathrm{C}^{16} \mathrm{O}^{16} \mathrm{O}$ (mass 44 ), ${ }^{13} \mathrm{C}^{16} \mathrm{O}^{16} \mathrm{O}$ (mass 45 ), and ${ }^{12} \mathrm{C}^{18} \mathrm{O}^{16} \mathrm{O}$ (mass 46) (higher masses are created from other combinations of ${ }^{13} \mathrm{C}$ and ${ }^{18} \mathrm{O}$, but these are rare and not routinely measured). From these ratios, the $\delta^{18} \mathrm{O}$ and $\delta^{13} \mathrm{C}$ of the sample are calculated simultaneously and quoted relative to VPDB. In reality, some complications have to be taken into account, notably subtraction of the contribution of molecules containing ${ }^{17} \mathrm{O}$ to the above masses, and the effect of isotopic fractionation associated with the phosphoric acid reaction.

\section{Foraminiferal calcite}

Foraminifera are single-celled eukaryotic organisms belonging to the Phylum Granuloreticulosa, which comprises amoeboid organisms characterized by pseudopodia that have a granular texture to the flowing cytoplasm (Lee et al., 


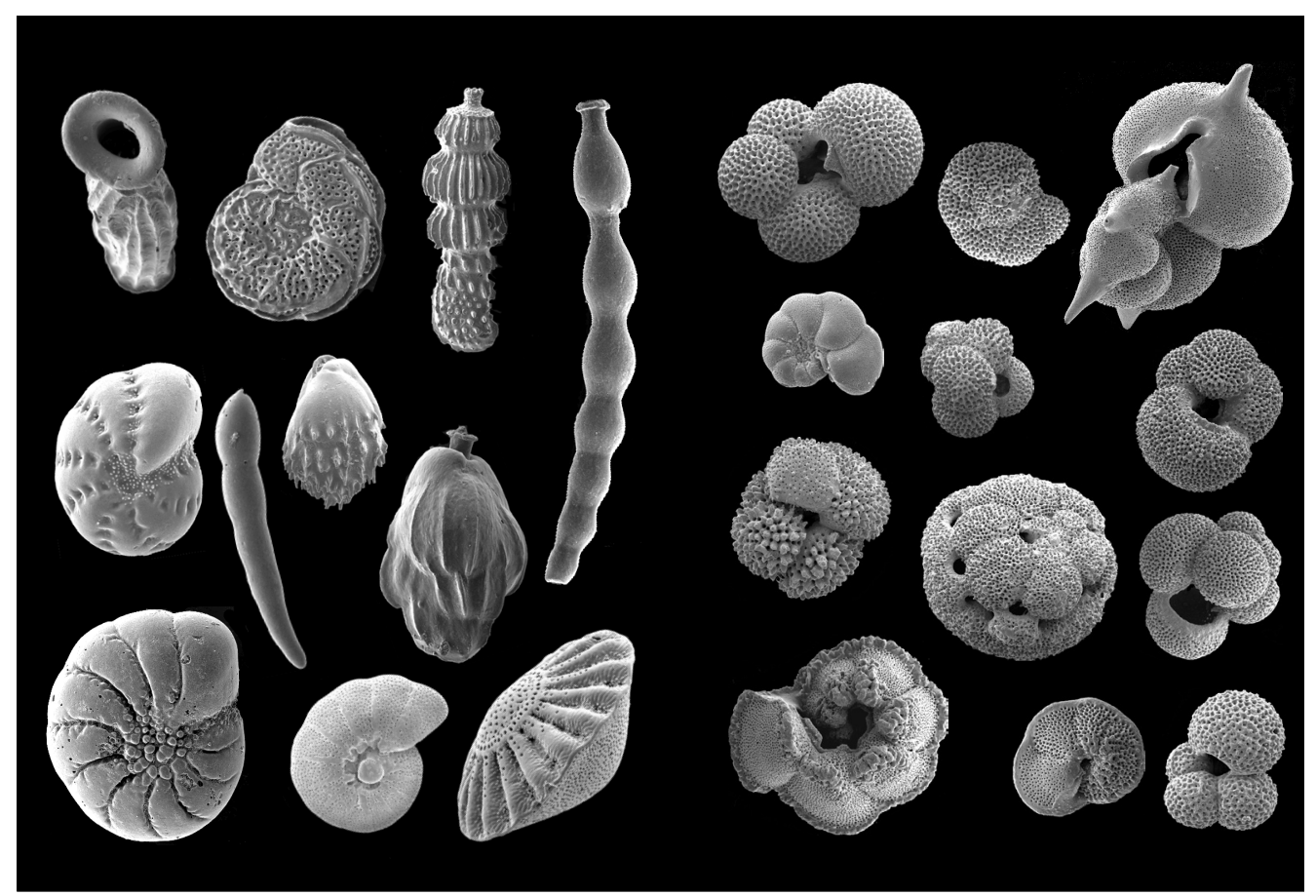

FIGURE 1.-Foram art: calcite tests of selected benthic (left) and planktonic (right) foraminifera. These are from exceptionally well-preserved Paleogene sediments of Tanzania (33-45 Ma). Scale is approximate; diameters are from about $0.20-0.75 \mathrm{~mm}$. Images: P. N. Pearson and I. K. McMillan. Note the literature is split between those who use the adjective 'planktonic' versus 'planktic' and between those who use 'benthonic' versus 'benthic'. It so happens that planktonic and benthic are clearly in the ascendancy as of 2012, by roughly 10:1 and 30:1 respectively, as shown by a word search on abstracts. It has been argued that planktic is the correct Greek form of the adjective (Rodhe, 1974; Emiliani, 1991) but it has been pointed out that planktonic, like electronic, is perfectly good English, however ugly it may be in Greek (Hutchinson, 1974). The majority usage is followed here.

2000). Most foraminifera are marine, and many secrete a test (or shell) made of calcium carbonate $\left(\mathrm{CaCO}_{3}\right.$; generally low-Mg calcite, but high-Mg calcite in porcelaneous species and aragonite in some groups). Some foraminifera live among the ocean plankton distributed in the upper part of the water column; others are benthic, living directly on the sea floor or at shallow depths in the sediment (Figure 1). Foraminifera are heterotrophs, feeding on organic matter rather than photosynthesizing, although many species live in symbiotic association with photosynthetic algae. Foraminiferal tests can occur in large numbers, and in many places, they form a significant component of the sea-floor sediment (for quantitative estimates, see Schiebel, 2002). The oxygen in foraminiferal calcite derives from the seawater (or, in the case of infaunal species, the pore water) in which the organism lived. Hence, the isotope ratios can provide information about the composition and history of that water, and the environmental conditions in which the test was secreted.

Most foraminiferal tests are built from suc- cessive chambers added episodically throughout life, starting with a first-formed chamber (proloculus). The chambers all have small openings or foramina (singular: foramen) that provide internal connections between them and allow cytoplasm flow inside and outside the test (hence 'foraminifera', which means 'bearers of foramina'). Generally, the chambers increase in size through the life cycle (ontogeny). Different groups of foraminifera have adopted a wide variety of chamber shapes and geometries of chamber addition, with spiral arrangements being the most common. This means that many types of foraminifera can be readily distinguished by eye (Figure 1). Foraminifer tests are large enough (mostly in the range $0.1-1.0 \mathrm{~mm}$ ) that they can be manually separated (picked) under a binocular microscope with a fine brush or needle, and their isotopic ratios can be determined either individually or by combining relatively small numbers of tests of the same species. This is a convenient advantage in paleoclimate research over smaller biogenic particles such as coccoliths, which are also very common in ma- 
rine carbonates, but cannot easily be separated into species, and are too small to analyze individually.

Foraminiferal life cycles generally last weeks or months, although there is evidence that some of very large $(>1 \mathrm{~cm})$ benthic species of the past may have lived for several years (Purton and Brasier, 1999). The complex process of test secretion (biomineralization) has been studied for many living species, both benthic (Erez, 2003) and planktonic (Hemleben et al., 1989). The details vary across the biological subgroups, as do the distinctive test microstructures that result. Chamber formation is always episodic with a period of rest and feeding in between. The solid chambers are constructed in a matter of hours from many millions of minute calcite plaques, or microgranules, which themselves are formed intracellularly (Hemleben et al., 1989).

In some species, seawater is vacuolated and transported inside the cell (Bentov et al., 2009). The vacuole in which the calcite is precipitated is separated from both seawater and cytoplasm by membranes (Erez, 2003). The chamber itself is formed on an organic template, and an organic membrane is found within the test wall of most species. The temperature within the cell is set by ambient conditions, but the observed rates of calcification are at least an order of magnitude slower than inorganic precipitation (Erez, 2003). Because the formation of calcite is so clearly biologically mediated, there is considerable potential for biological fractionation of the various isotopes and trace metals incorporated into the calcite (see Zeebe et al., 2008, for a review). Despite this, foraminifera have been found to secrete calcium carbonate close to isotopic equilibrium, unlike certain other types of calcifiers such as corals, echinoderms, and arthropods (Wefer and Berger, 1991). However, small but significant disequilibrium effects (sometimes called vital effects) have been reported and are discussed further below.

\section{The heroic age of oxygen isotopes}

As mentioned above, a molecule with a heavy isotope has a slightly greater covalent bond strength and a lower vibrational frequency than its lighter counterpart so it is slightly less reactive. This difference in reactivity is influenced by the ambient temperature such that an increase in temperature lessens the difference in reaction rates (essentially, this is because everything vibrates faster at higher temperature). The idea that this effect could be exploited by measuring the oxy- gen isotope ratio of a calcite shell to determine its temperature of calcification dates back to the work of Harold Urey and colleagues (Urey, 1947, 1948; the latter paper reports results of collaborative work between himself, Charles McKinney, John McCrea, and Samuel Epstein at the University of Chicago; see also Epstein, 1997, for a personal account of the period). Urey (1947) began his investigation by making calculations of the isotope exchange reaction between water and carbonate ions. As he himself explained: "If calcium carbonate is crystallized slowly in the presence of water at $0^{\circ} \mathrm{C}$, the calculations show that the ratio of the oxygen isotopes in the calcium carbonate should be 1.026 to 500 if the ratio of the isotopes in the water is 1 to 500 , i.e. oxygen 18 is very slightly concentrated in the calcium carbonate in relation to the water. On the other hand, if the temperature is $25^{\circ} \mathrm{C}$, the oxygen isotopes will be concentrated only to the extent of 1.022 as compared with 1 in 500 on water. This shows that there is a slight temperature coefficient for the abundance of ${ }^{18} \mathrm{O}$ isotope in the calcium carbonate." (Urey, 1948, p. 491; note that these figures would now be revised somewhat.)

Urey (1948) pointed out that these differences, although small, were measurable and consistent with the actual isotopic ratios of a variety of biogenic carbonates that he and his colleagues measured to investigate the effect. They did this on a pioneering mass spectrometer built to the design of Alfred Nier (see Nier, 1947, and McKinney et al., 1950, for early analytical developments). Among the carbonates measured were two samples of Globigerina ooze from the Pacific Ocean at $60^{\circ} \mathrm{S}$. Globigerina is a genus of planktonic foraminifer, hence, these were the first of the very many foraminifera to be dissolved and analyzed in the pursuit of temperature information. The $\delta^{18} \mathrm{O}$ values of these samples were reported as +2.14 and +1.85 relative to a mollusk that grew at $13^{\circ} \mathrm{C}$ (note the PDB standard had yet to be defined). These enriched isotope ratios implied a cooler calcification temperature for the foraminifera than the mollusk, which was consistent with the high-latitude location. "I suddenly found myself with a geologic thermometer in my hands," Urey is reported to have said (Emiliani, 1958, p. 2). Although he also admitted it was "not useful" (Epstein, 1997, p. 8), it was evidently an interesting problem and, in the immediate postwar period, a welcome non-military application of isotope physics. Urey (1948) reported measurements of a variety of samples from the Cretaceous 
chalk of England to underline his point, estimating temperatures of 17 to $27^{\circ} \mathrm{C}$. However, he also identified several caveats that remain centrally important: that the isotope ratio of the water in which the calcite grew could have changed through time, which would change the baseline for the calculation; that biological disequilibrium effects might be expected (later called 'vital effects' by Urey et al., 1951); and that the preservation of many fossils may not be good enough for a reliable measurement to be made.

The theory of mass-dependent fractionation of the isotopes applies well to gases, but only approximately to liquids and not at all to ionic crystals (Faure and Mensing, 2005). Hence, it is necessary to conduct experiments to empirically determine the actual temperature relationship by growing calcite at different temperatures. This job was given to Urey's graduate student, John McCrea, who published the first oxygen-isotope paleotemperature equation based on inorganically grown calcite crystals, and showed that it was close to the theoretical expectation (McCrea, 1950). A revised version of this temperature scale based on analyses of mollusk shells grown between 7 and $30^{\circ} \mathrm{C}$ was published by Epstein et al. (1953). The historic Epstein et al. (1953) paleotemperature equation is:

$\mathrm{T}\left({ }^{\circ} \mathrm{C}\right)=16.5-4.3\left(\delta^{18} \mathrm{O}_{\mathrm{cc}}-\delta^{18} \mathrm{O}_{\mathrm{sw}}\right)+0.14\left(\delta^{18} \mathrm{O}_{\mathrm{cc}}-\right.$ $\left.\delta^{18} \mathrm{O}_{\mathrm{sw}}\right)^{2}$

where $\delta^{18} \mathrm{O}_{\mathrm{cc}}$ is the measured value in calcium carbonate and $\delta^{18} \mathrm{O}_{\mathrm{sw}}$ is the isotope ratio of the water from which it is precipitated. The slope of this relationship means that a $0.23 \%$ increase in $\delta^{18} \mathrm{O}_{c c}$ corresponds to a difference of about $1^{\circ} \mathrm{C}$. There are many subsequent variants of this equation, but they mostly take the same general form. Refinements and developments of paleotemperature equations are discussed in the following section.

Further Mesozoic analyses were reported by Urey et al. (1951) in a celebrated paper that included the presentation of a series of measurements through the rostrum of a Jurassic belemnite from Scotland, from which it was argued that the organism lived through four seasonal cycles. The presentation of these results at the Geological Society of America annual meeting in 1950 reportedly caused a sensation (Allègre, 2008). Other specimens analyzed were belemnites from the Maastrichtian Pee Dee Formation of Carolina, which subsequently became the basis for the PDB laboratory standard that is still in use today as VPDB (Craig, 1953, 1965).

The application of oxygen isotope techniques to foraminifera was developed by another of Harold Urey's research associates, the micropaleontologist Cesare Emiliani. Emiliani first turned his attention to planktonic foraminifera, manually separating various species for analysis. Using a sample of sea-floor sediment from the Caribbean, he showed that different species from the same sample had significantly different oxygen isotope ratios, which he interpreted as representing different depth habitats (Emiliani, 1954a). At that time, relatively little was known of planktonic foraminiferal depth ecology, but Emiliani's insight proved correct, as has been demonstrated subsequently in innumerable plankton tows and nets (summarized by Hemleben et al., 1989; see also Mulitza et al., 1997, 1999).

Emiliani then turned his attention to benthic foraminifera with the aim of determining the past temperature of the sea floor, which had previously been regarded as a constant environment. He compared the $\delta^{18} \mathrm{O}$ paleotemperatures of calcareous benthic foraminifera from Oligocene, Miocene, and Pliocene samples from the Pacific Ocean and estimated that deep-sea temperatures had declined from 10.4 to 7.0 to $2.2^{\circ} \mathrm{C}$ across these epochs (Figure 2). This, he noted, was consistent with abundant geological and paleobotanical evidence for global cooling during the Cenozoic (Emiliani, 1954b; see also Emiliani, 1961).

This discovery has been hailed as the foundation point of the science of paleoceanography

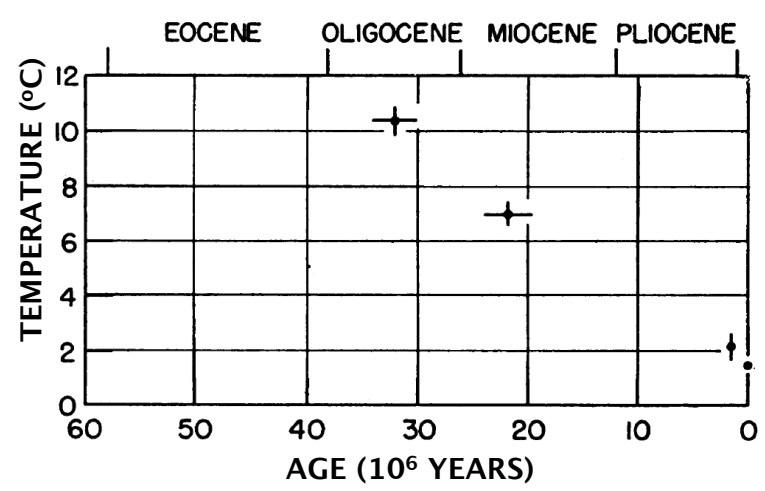

FIGURE 2.-The birth of paleoceanography? Temperature estimates of Pacific deep waters in the Cenozoic from four oxygen isotope analyses of benthic foraminifera (modified from Emiliani, 1954b). Note the numerical timescale has been modified considerably since initial publication. 


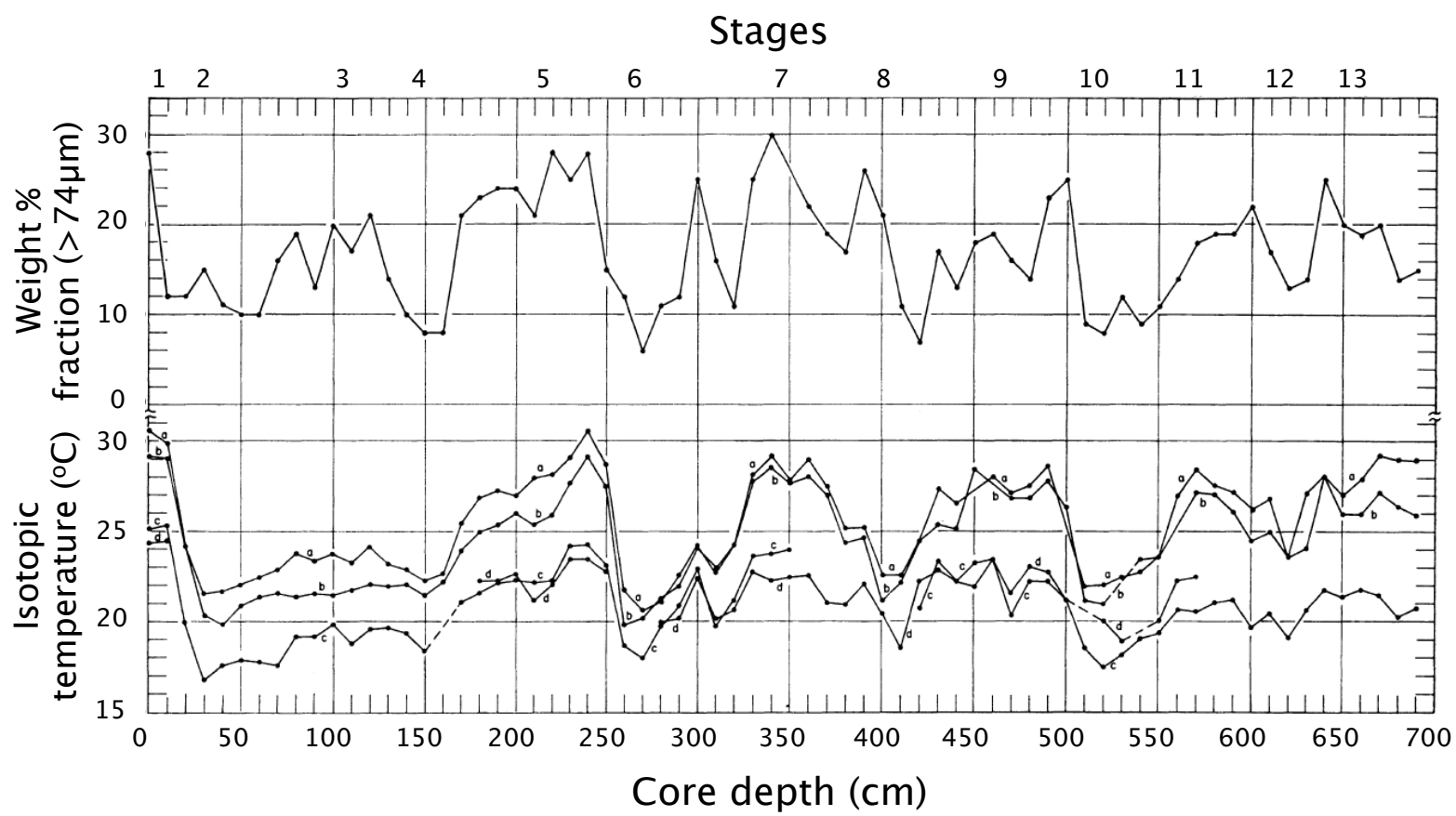

FIGURE 3.-First view of the glacial cycles from oxygen isotopes: coarse sediment fraction (top panel) and planktonic foraminiferal oxygen-isotope paleotemperature estimates (bottom panel) from Piston Core A-1794 (Caribbean, Lamont Geological Observatory). Isotope 'stages' are labeled at the top. Temperature offsets between the planktonic foraminifer species are mainly related to depth habitat (and hence temperature) of calcification. This record is now considered to span $\sim 400 \mathrm{kyr}$. (compare with Figure 12). Small letters represent different species. Modified from Emiliani, 1955.

(Hay and Zakevich, 1999). However, just as important was his subsequent work on piston cores of marine sediments spanning the late Pleistocene to Recent. Analyzing planktonic foraminifera from these cores, Emiliani (1955) demonstrated the existence of a series of glacial cycles, which he numbered as 'isotope stages' back through time by taking successive isotopic maxima and minima (Figure 3), a notation system that is still in widespread use. These isotopic cycles corresponded to micropaleontological assemblage variations in the same cores that were interpreted as representing surface ocean-temperature changes (Ericson and Wollin, 1956). Emiliani (1955) argued that his record supported the orbital theory of the ice ages that had been developed in the nineteenth century (Croll, 1875), and elaborated further in the earlier twentieth century (Milankovitch, 1941).

Emiliani (1955) knew that the waxing and waning of the great ice sheets would have had an affect on whole-ocean $\delta^{18} \mathrm{O}_{\mathrm{sw}}$, thereby changing the baseline for his paleotemperature calculations. Specifically, ice sheets are expected to be isotopically depleted with respect to ${ }^{18} \mathrm{O}$ because they are formed from high-latitude water vapor, which is itself depleted after evaporation and condensation fractionations on its journey from the ocean to the poles. Hence the growth of ice sheets would leave the ocean isotopically enriched (and, simultaneously, lower sea level). Conversely, melting of the ice would recirculate the isotopically depleted fresh water. Subtracting this effect, Emiliani (1955) estimated that sea-surface temperatures had varied by about $6^{\circ} \mathrm{C}$ between glacial minima and interglacial maxima (Figure 3).

Subsequent measurements of polar ice proved to be more depleted than Emiliani had originally thought, so his calculations are now thought to have underestimated the ice volume effect. Alternative calculations by Olausson (1965) indicated that the entire amplitude of glacial/interglacial $\delta^{18} \mathrm{O}$ variability could be explained by the ice effect rather than temperature. This controversy approached resolution when Shackleton (1967) analyzed benthic foraminifer $\delta^{18} \mathrm{O}$ data from one of Emiliani's cores and showed they had a similar amplitude of variation to the planktonic data. The covariation of benthic and planktonic $\delta^{18} \mathrm{O}$ is explained more easily by whole ocean changes in $\delta^{18} \mathrm{O}_{\text {sw }}$ than it is by temperature; moreover, it is simply not possible to lower the glacial tempera- 
ture of bottom water by $6^{\circ} \mathrm{C}$ compared with modern ocean water, because that would put it below freezing (Shackleton, 1967; see also Dansgaard and Tauber, 1969).

Shackleton's interpretation has tended to prevail, especially following the CLIMAP (Climate: Long-Range Investigation Mapping and Prediction) project in the 1970 s, which mapped ice age temperature estimates worldwide using microfossil assemblage data (CLIMAP Project Scientists, 1976). Hence, the deep-sea oxygen isotope records of the Pleistocene are now interpreted more as a signal of global ice-volume fluctuation rather than temperature, although a component of temperature change is also present in the records and, in some instances, that component can be several degrees (see, e.g., Schrag et al., 2002; Herbert et al., 2010). Emiliani never fully accepted the Shackleton interpretation of the planktonic records, arguing that the CLIMAP data overestimated glacial sea-surface temperatures (see Emiliani, 1992, and Herbert et al., 2010, for more on the controversy).

Emiliani's great discoveries in the 1950s were made possible, in part, by the piston-coring system developed by Borje Kullenberg and famously deployed aboard the motor-schooner Albatross in the worldwide Swedish Deep Sea Expedition (1947-8). It was then used by the Lamont Geological Observatory in the Caribbean (see Olausson, 1996, for review). These cores could be up to about $20 \mathrm{~m}$ long. The potential of even deeper drilling was proven by Project Mohole, which, in 1961, drilled $183 \mathrm{~m}$ of sediment and basalt from a single hole in the Guadeloupe Basin (as reviewed by National Research Council, 2011). The following year, Emiliani proposed to develop long paleoclimate records using an innovative drilling platform, the $M / V$ Submarex. This vessel had been a wartime patrol boat, but was later converted by an oil-industry consortium into an experimental drill ship - allegedly the first of its kind - with a derrick mounted on the port side. Its name alludes to the fact that it was a sub-marine explorer, not an ex-submarine chaser! Emiliani's project was called LOCO (for Long Cores). In 1963, the Submarex successfully recovered $55 \mathrm{~m}$ of pelagic sediment from a single hole. Emiliani's LOCO advisory group developed into the JOIDES (Joint Oceanographic Institutes for Deep Earth Sampling) committee that supervised further deep drilling off of Florida. This soon led to the formation of the Deep Sea Drilling Project (DSDP) in 1967, with a drill ship specially designed by
Global Marine Inc., named the GLOMAR Challenger (see Winterer, 2000, and National Research Council, 2011, for historical reviews).

Scientific ocean drilling has continued ever since under continuations of this program: the Ocean Drilling Program (ODP; using the drillship JOIDES Resolution) and Integrated Ocean Drilling Program (IODP; using multiple drilling platforms). These programs have completely transformed our understanding of Earth's climate history, and oxygen isotope analysis of foraminiferal tests has always been one of the most important tools in researching Earth's past climate (National Research Council, 2011).

\section{Equations, corrections, offsets}

As described above, McCrea (1950) published the first laboratory oxygen-isotope paleotemperature equation, which was subsequently revised by Epstein et al. (1953). Since then, many other empirically derived equations have been published using either inorganic calcite precipitates or various sorts of organisms grown in culture or collected in the field across a temperature range. In general, the paleotemperature equations take the quadratic form:

$\mathrm{T}\left({ }^{\circ} \mathrm{C}\right)=a+b\left(\delta^{18} \mathrm{O}_{\mathrm{cc}}-\delta^{18} \mathrm{O}_{\mathrm{sw}}\right)+c\left(\delta^{18} \mathrm{O}_{\mathrm{cc}}-\delta^{18} \mathrm{O}_{\mathrm{sw}}\right)^{2}$

where $\delta^{18} \mathrm{O}_{\mathrm{cc}}$ is the measured value in calcite and $\delta^{18} \mathrm{O}_{\mathrm{sw}}$ is the isotope ratio of the water from which the calcite is precipitated (standardized to the VPDB scale). The coefficients $a, b$, and $c$ are determined experimentally. The term $a$ represents the temperature when $\delta^{18} \mathrm{O}_{\mathrm{cc}}=\delta^{18} \mathrm{O}_{\mathrm{sw}}, b$ is the slope (always negative), and $c$ is the second-order term for the (always slight) curvature of the slope arising from the fact that isotopic fractionation decreases with increasing temperature. Some of the published equations are simplified by the fact that $c$ is set at zero, and therefore, the relationship between $\mathrm{T}$ and $\delta^{18} \mathrm{O}$ is linear. The reason for this is that the curvature is so slight, a straight line provides just as good a statistical fit over the desired temperature range. (Note that even the standard quadratic is only an approximation to the theoretically expected relationship, which is logarithmic.)

A tricky aspect of the paleotemperature equations is that $\delta^{18} \mathrm{O}_{\mathrm{sw}}$ values are always measured on the VSMOW scale (or, before that was defined, the SMOW scale or something equivalent), but to be used in equations that are expressed in the form given above (which is usual in paleoclimate 
studies) they must be standardized to the VPDB (or PDB) scale. This means a small but significant correction or conversion factor must be applied to the $\delta^{18} \mathrm{O}_{\text {sw }}$ value. This conversion simultaneously corrects for the following: 1) that the absolute scales are offset from each other; and 2) that there is an experimental difference in the fractionation of the oxygen isotopes that occurs when reacting carbonate with phosphoric acid at $25^{\circ} \mathrm{C}$ (as is done with calcite samples) versus that caused in the equilibrium between water and $\mathrm{CO}_{2}$ at $25.3^{\circ} \mathrm{C}$ (as is done with water samples) (see Grossman, 2012, for more details). If this was not complicated enough, it is important to appreciate that the accepted value for the (V)SMOW to (V)PDB conversion has changed through time. The original value taken by Epstein et al. (1953) was thought to be $-0.20 \%$. This was subsequently revised to $-0.22 \%$ (Friedmann and O'Neil, 1977) and $-0.27 \%$ (Hut, 1987). When using old equations, it is generally necessary to use the value that was assumed in the original study in order to be faithful to the original calibration (see Bemis et al., 1998, for review). However, as Grossman (2012) points out, that rule does not apply to the original Epstein et al. (1953) equation because it was directly standardized with PDB-derived $\mathrm{CO}_{2}$, so in that case, the currently accepted value of $-0.27 \%$ is appropriate.

A problem that gradually became apparent from field studies is that the paleotemperature equations were repeatedly found to give temperatures that are slightly too high by $\sim 1-2^{\circ} \mathrm{C}$ compared with in-situ temperature measurements (Shackleton et al., 1973; Kahn, 1979; Williams et al., 1981; Deuser and Ross, 1981; Sautter and Thunell, 1991; Mulitza et al., 2003; see discussion in Bemis et al., 1998). Hence, it seems that some significant (albeit fairly minor overall) vital-effect fractionation may occur in some foraminifera (Shackleton et al., 1973). An experimental breakthrough was made by Spero (1992), Spero and Lea (1993), and Spero et al. (1997), who found that the carbonate ion concentration $\left[\mathrm{CO}_{3}{ }^{2-}\right]$ and $\mathrm{pH}$ local to the planktonic foraminifer test was associated with a significant, additional, negative fractionation of the oxygen isotopes. These parameters might be affected by various biological processes local to the foraminifera. The most notable of these is the presence of a cloud of photosynthetic symbionts in some species that would be expected to lower the $\mathrm{pH}$ and increase the $\left[\mathrm{CO}_{3}{ }^{2-}\right]$ locally (Rink et al., 1998). In an elegant series of experiments, efforts were made to determine dif-

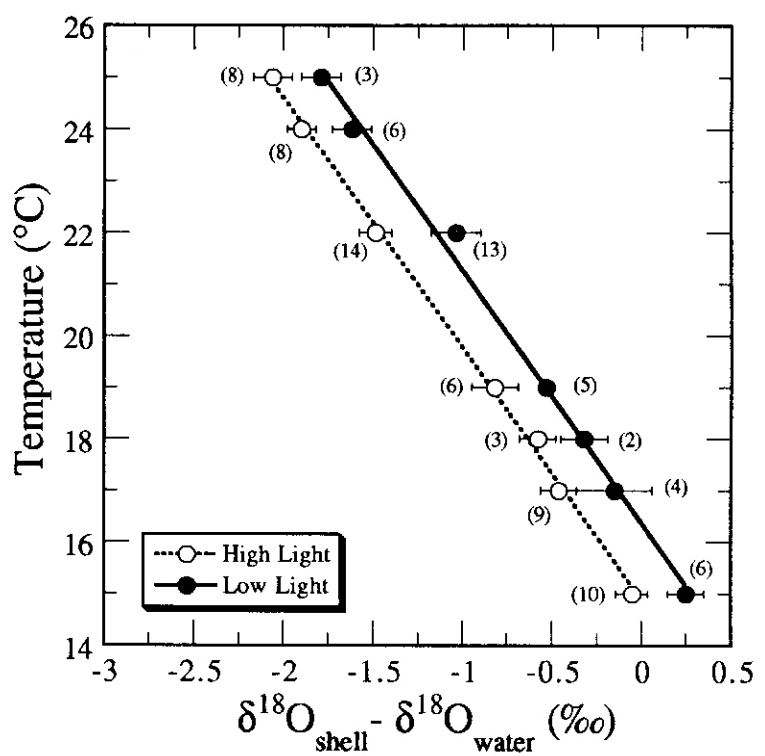

FIGURE 4.- The carbonate chemistry effect unmasked. Experimental calibrations of the planktonic foraminifer Orbulina universa in high light (with symbiont activity) and low light (without symbiont activity). Numbers in brackets represent numbers of specimens measured. The offset in the calibrations is attributed to the non-ambient carbonate chemistry of the microenvironment of calcification (see text). Modified from Spero (1988) after Bemis et al. (1988). Note that the $\delta^{18} \mathrm{O}$ scale is not directly comparable with Figure 5 because the VSMOW-VPDB conversion is not incorporated on this figure.

ferent equations for a symbiotic species (Orbulina universa) grown in different irradiance levels (and hence levels of symbiotic activity) (Spero, 1992; Bemis et al., 1998; Bijma et al., 1999). Interestingly, the temperature: $\delta^{18} \mathrm{O}$ relationship for $O$. universa grown in low light is very close to that obtained by Kim and O'Neil (1997) for inorganic calcite (see also Spero and Lea, 1993), but there is a clear and consistent offset of about $-0.3 \%$ for high light conditions (Figure 4). The offset was even greater for $O$. universa grown in artificially high $\left[\mathrm{CO}_{3}{ }^{2-}\right]$. More recently, similar $\left[\mathrm{CO}_{3}{ }^{2-}\right]$ effects have been suggested for benthic foraminifera (Rathmann and Kuhnert, 2008; Rollion-Bard et al., 2008), and experimentally measured in a coccolithophore and a calcareous dinoflagellate (Ziveri et al., 2012). However, the slopes of some of the experimentally determined relationships between $\delta^{18} \mathrm{O}$ and $\left[\mathrm{CO}_{3}{ }^{2-}\right]$ differ markedly.

A simple explanation for the underlying process responsible for the $\left[\mathrm{CO}_{3}{ }^{2-}\right]$ effect was proposed by Zeebe (1999), who related it to isotopic 
fractionation between the species of dissolved inorganic carbon $\left(\mathrm{H}_{2} \mathrm{CO}_{3}, \mathrm{HCO}_{3}{ }^{-}\right.$and $\left.\mathrm{CO}_{3}{ }^{2-}\right)$ as a function of $\mathrm{pH}$ (Zeebe, 1999). Zeebe (2001) calculated a theoretical value of $-1.42 \%$ in $\delta^{18} \mathrm{O}$ for every 1 unit increase in $\mathrm{pH}$, although experimental determinations of the relationship are still not closely constrained (Spero et al., 1997; Beck et al., 2005). This explanation indicates that the use of the equations such as Kim and O'Neil (1997) would yield temperatures too high by $\sim 1.5^{\circ} \mathrm{C}$ in symbiotic species. It also suggests that for paleoapplications, a value for $\mathrm{pH}$ as well as $\delta^{18} \mathrm{O}_{\mathrm{sw}}$ should be estimated or assumed, especially if large differences in the carbonate system might be expected during the geological past (e.g., Wilson et al., 2002; Bice et al., 2006; Zeebe, 2012), or across some past climatic event (Zeebe et al., 2008; Uchikawa and Zeebe, 2010).

Although many shallow-water benthic foraminifera have photosymbiotic relationships with algae, foraminifera that are commonly used in deep-sea paleoclimate research do not because they live well below the photic zone. One might expect, then, that their paleotemperature curves would lie close to the inorganic relationship. This is indeed the case for some species, but others were found to have consistent offsets (Duplessey et al., 1970; Shackleton and Opdyke, 1973; Shackleton, 1974; Graham et al., 1981; and many subsequent studies). The initial view was that the families Buliminacea (including the common deep-sea genus Uvigerina) and Cassidulinacea give values that are generally close to equilibrium, whereas the Discorbacea and Rotaliacea (including Cibicidoides) usually give variable negative offsets averaging about $-1 \%$ (Grossman, 1987). Hence, for deep-sea compilations, it became standard practice to adjust Cibicidoides values by a fixed number to bring them into line with Uvigerina data (see review by Wefer and Berger, 1991). Subsequently, it has been pointed out (Bemis et al., 1998; Lynch-Stieglitz et al., 1999; Costa et al., 2006) that if one uses the more recent paleotemperature equation of Kim and O'Neil (1997), Cibicidoides gives values that are closer to equilibrium than does Uvigerina, hence current studies adjust data from other genera to bring them into line with Cibicidoides, and use a paleotemperature equation calibrated to that genus (e.g., Cramer et al., 2009, 2011). Another problem that must be confronted when using benthic foraminiferal $\delta^{18} \mathrm{O}$ in deep time is that the offsets between common species and genera may have changed over multimillion-year timescales, possi- bly because of biological evolution (Vincent et al., 1985; Katz et al., 2003).

Part of the reason for the offsets between species of benthic foraminifera may be that some are infaunal and some epifaunal, so they calcify in environments with different $\mathrm{pH}$ levels (Bemis et al., 1998; Cramer et al., 2011). Also likely is that while making their test, some foraminifera incorporate a component of isotopically light metabolic oxygen that originates from their own respired $\mathrm{CO}_{2}$ (Erez, 1978). It has been suggested that species adapted to low oxygen conditions on the sea floor may have special adaptations enabling oxygen exchange with their environment, and so tend to precipitate their tests closer to equilibrium than other species (Grossman, 1987). Several studies have now been published reporting experimental results from deep-sea benthic foraminifera grown in culture (Wilson-Finelli et al., 1998; McCorkle et al., 2008; Barras et al., 2009; Fillipson et al., 2010). The temperature relationships of the cultured species are encouragingly close to the published inorganic paleotemperature relationship. However, there appears to be an additional ontogenetic (growth) effect whereby young/small individuals precipitate their tests with a slight negative offset. This may be because they recycle a higher proportion of oxygen from metabolic $\mathrm{CO}_{2}$ (Barras et al., 2009; Fillipson et al., 2010).

In general, the oxygen-isotope technique is very good at identifying relative temperature changes because the slopes of the published relationships are all quite similar, but the possibility of a systematic offset from equilibrium should always be considered in the light of the literature. Clearly, a general rule in any oxygen isotope study based on foraminifera that is designed to determine variations down-core is that a single species should be measured from a restricted size range. This means the sometimes subtle morphological distinctions between species need to be known and appreciated.

Considering all this, we come to the question: which paleotemperature equation should one use? There is no right answer to this because it depends on the application. For example, does one prefer an inorganic calibration or one appropriate for the target organism? Which is best, a laboratory culture study or one based on in-situ collections and measurements taken in the ocean? Is a new and more tightly calibrated equation to be preferred to a more widely used historical equation, even if the differences between them are small? To help in this decision, some of the most prominent histori- 
TABLE 1.-Comparison of some prominent paleotemperature equations for calcite $\delta^{18} \mathrm{O}$. Note that in each case the $\delta^{18} \mathrm{O}_{\mathrm{sw}}$ term is quoted relative to VSMOW so it is also necessary to add to it the appropriate VSMOW to VPDB conversion current at the time the equation was calibrated, as given in the last column (see text for details).

\begin{tabular}{|c|c|c|c|c|}
\hline Reference & Material & $\begin{array}{l}\text { Calibra- } \\
\text { tion range } \\
\left({ }^{\circ} \mathrm{C}\right)\end{array}$ & Equation & $\begin{array}{l}\text { VSMOW } \\
\text { to VPDB } \\
\text { conversion }\end{array}$ \\
\hline Epstein et al. (1953) & Mollusk shell & $7.2-29.5$ & $\begin{array}{c}\mathrm{T}\left({ }^{\circ} \mathrm{C}\right)=16.5-4.3\left(\delta^{18} \mathrm{O}_{\mathrm{cc}}\right. \\
\left.\delta^{18} \mathrm{O}_{\mathrm{sw}}\right)+0.14\left(\delta^{18} \mathrm{O}_{\mathrm{cc}}-\delta^{18} \mathrm{O}_{\mathrm{sw}}\right)\end{array}$ & -0.27 \\
\hline $\begin{array}{l}\text { O'Neil et al. (1969) reformu- } \\
\text { lated by Shackleton (1974) }\end{array}$ & $\begin{array}{l}\text { Synthetic calcite and } \\
\text { calcite-water ex- } \\
\text { change }\end{array}$ & $0-500$ & $\begin{array}{c}\mathrm{T}\left({ }^{\circ} \mathrm{C}\right)=16.9-4.38\left(\delta^{18} \mathrm{O}_{\mathrm{cc}^{-}}\right. \\
\left.\delta^{18} \mathrm{O}_{\mathrm{sw}}\right)+0.10\left(\delta^{18} \mathrm{O}_{\mathrm{cc}}-\delta^{18} \mathrm{O}_{\mathrm{sw}}\right)\end{array}$ & -0.20 \\
\hline Horibe and Oba (1972) & Cultured mollusks & $4.5-23.3$ & $\begin{array}{c}\mathrm{T}\left({ }^{\circ} \mathrm{C}\right)=17.04-4.34\left(\delta^{18} \mathrm{O}_{\mathrm{cc}^{-}}\right. \\
\left.\delta^{18} \mathrm{O}_{\mathrm{sw}}\right)+0.16\left(\delta^{18} \mathrm{O}_{\mathrm{cc}^{-}}\right. \\
\left.\delta^{18} \mathrm{O}_{\mathrm{sw}}\right)\end{array}$ & -0.20 \\
\hline Erez and Luz (1983) & $\begin{array}{l}\text { Cultured } \\
\text { Globigerinoides } \\
\text { sacculifer (plank- } \\
\text { tonic foraminifera) }\end{array}$ & $14-30$ & $\begin{array}{c}\mathrm{T}\left({ }^{\circ} \mathrm{C}\right)=17.0-4.52\left(\delta^{18} \mathrm{O}_{\mathrm{cc}}\right. \\
\left.\delta^{18} \mathrm{O}_{\mathrm{sw}}\right)+0.03\left(\delta^{18} \mathrm{O}_{\mathrm{cc}}-\delta^{18} \mathrm{O}_{\mathrm{sw}}\right)\end{array}$ & -0.22 \\
\hline $\begin{array}{l}\text { Kim and O'Neil (1997) re- } \\
\text { formulated by Bemis et al. } \\
(1998)\end{array}$ & Synthetic calcite & $10-40$ & $\begin{array}{c}\mathrm{T}\left({ }^{\circ} \mathrm{C}\right)=16.1-4.64\left(\delta^{18} \mathrm{O}_{\mathrm{cc}^{-}}\right. \\
\left.\delta^{18} \mathrm{O}_{\mathrm{sw}}\right)+0.09\left(\delta^{18} \mathrm{O}_{\mathrm{cc}}-\delta^{18} \mathrm{O}_{\mathrm{sw}}\right)\end{array}$ & -0.27 \\
\hline Bemis et al. (1998) & $\begin{array}{l}\text { Cultured Orbulina } \\
\text { universa (high light) } \\
\text { (planktonic fora- } \\
\text { mininifera) }\end{array}$ & $15-25$ & $\begin{array}{c}\mathrm{T}\left({ }^{\circ} \mathrm{C}\right)=14.9-4.80\left(\delta^{18} \mathrm{O}_{\mathrm{cc}^{-}}\right. \\
\left.\delta^{18} \mathrm{O}_{\mathrm{sw}}\right)\end{array}$ & -0.27 \\
\hline $\begin{array}{l}\text { Lynch-Stieglitz et al. (1999) } \\
\text { as arranged by Cramer et al. } \\
(2011)\end{array}$ & $\begin{array}{l}\text { In-situ Cibicidoides } \\
\text { and Planulina (ben- } \\
\text { thic foramininifera) }\end{array}$ & $4-26$ & $\begin{array}{c}\mathrm{T}\left({ }^{\circ} \mathrm{C}\right)=16.1-4.76\left(\delta^{18} \mathrm{O}_{\mathrm{cc}^{-}}\right. \\
\left.\delta^{18} \mathrm{O}_{\mathrm{sw}}\right)\end{array}$ & -0.27 \\
\hline $\begin{array}{l}\text { Mielke (2001) in Spero et al. } \\
(2003)\end{array}$ & $\begin{array}{l}\text { Cultured Globoro- } \\
\text { talia menardii } \\
\text { (planktonic fora- } \\
\text { minifera) }\end{array}$ & $?$ & $\begin{array}{c}\mathrm{T}\left({ }^{\circ} \mathrm{C}\right)=14.9-5.13\left(\delta^{18} \mathrm{O}_{\mathrm{cc}^{-}}\right. \\
\left.\delta^{18} \mathrm{O}_{\mathrm{sw}}\right)\end{array}$ & -0.27 \\
\hline $\begin{array}{l}\text { Spero et al. (unpublished) in } \\
\text { Spero et al. (2003) }\end{array}$ & $\begin{array}{l}\text { Cultured Globigeri- } \\
\text { noides sacculifer } \\
\text { (high light) (plank- } \\
\text { tonic foraminifera) }\end{array}$ & $?$ & $\begin{array}{c}\mathrm{T}\left({ }^{\circ} \mathrm{C}\right)=\underset{ }{12.0-5.57\left(\delta^{18} \mathrm{O}_{\mathrm{cc}^{-}}\right.} \\
\left.\delta^{18} \mathrm{O}_{\mathrm{sw}}\right)\end{array}$ & -0.27 \\
\hline Mulitza et al. (2003) & $\begin{array}{l}\text { In-situ Globigeri- } \\
\text { noides sacculifer } \\
\text { (high light) (plank- } \\
\text { tonic foraminifera) }\end{array}$ & $16-31$ & $\begin{array}{c}\mathrm{T}\left({ }^{\circ} \mathrm{C}\right)=14.91-4.35\left(\delta^{18} \mathrm{O}_{\mathrm{cc}}\right. \\
\left.\delta^{18} \mathrm{O}_{\mathrm{sw}}\right)\end{array}$ & -0.27 \\
\hline
\end{tabular}




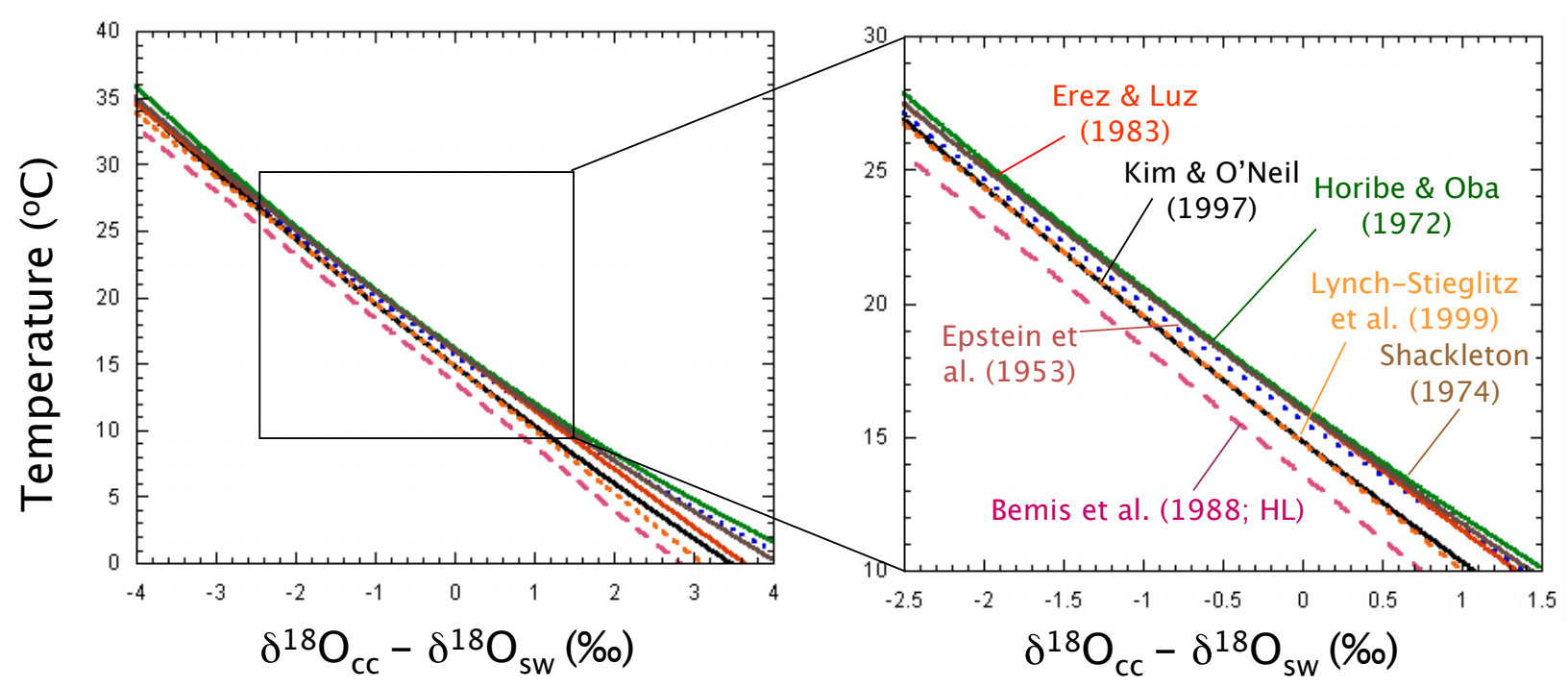

FIGURE 5.- Seven leading paleotemperature equations compared. Note that the VSMOW to VPDB conversions for the $\delta^{18} \mathrm{O}_{\text {sw }}$ term of the respective equations (see text) have been incorporated, making them directly comparable. The equations are shown extending beyond their calibration ranges for illustrative purposes. Note that when the Uvigerina-Cibicdoides offset is applied, the benthic equations of Shackleton (1974) and Lynch-Steiglitz et al. (1999) are brought much closer together than they appear on this plot. They do diverge at the warm end, which makes the choice of equation more critical for Paleogene deep-water temperatures than it is for the colder Neogene.

cal and current equations are given in Table 1, and a subset is compared graphically in Figure 5.

The original Epstein et al. (1953) equation was based on mollusks and it was only calibrated down to $7^{\circ} \mathrm{C}$. Shackleton (1974) argued that the equation of O'Neil et al. (1969), as rearranged by him, was more appropriate to use at low temperatures typical of deep-sea benthic foraminifera. The Shackleton (1974) equation arguably has been superseded by a more recent set of experimental results made on inorganic calcite by Kim and O'Neil (1997), and converted to quadratic form by Bemis et al (1998). That equation is, however, defined only by measurements made at 10,25 , and $40^{\circ} \mathrm{C}$. For those working with benthic foraminifera, the equation calculated for core-top samples down to $4.1^{\circ} \mathrm{C}$ by Lynch-Stieglitz et al. (1999) as rearranged by Cramer et al. (2011) currently is the best-constrained field calibration, as it is based on a large data set.

For planktonic foraminifera, the equation of Erez and Luz (1983) has been used in the literature frequently (note that a minor variant of this equation is sometimes quoted in the literature with the coefficients $a=16.998, b=-4.52$, and $c$ $=0.028$ based on Table 1 of Erez and Luz, 1983). This equation was the first to be calibrated using foraminifera in culture (specifically Globigerinoides sacculifer, a widely used species) between 14 and $30^{\circ} \mathrm{C}$. More recent culture experiments (Spero et al., 2003) and in-situ field observations (e.g., Mulitza at al., 2003) have suggested that the Erez and Luz (1983) equation significantly overestimates temperatures by about $2^{\circ} \mathrm{C}$ (Mulitza et al., 2003). One possible reason for this is the carbonate chemistry of the culture experiments: as pointed out by Bemis et al. (1998), precise illumination data and carbonate $\mathrm{ion} / \mathrm{pH}$ data are not available for them. A variety of species-specific equations have been developed using culture experiments (Table 1). For studies that are based on data from these particular species, the best choice is probably to use the most recent appropriate equation. For studies that use other planktonic foraminifera species, including the many studies that use extinct ones in deep time, a reasonable approach would be to use the inorganic relationship of Kim and O'Neil (1997), and acknowledge that offsets equivalent to about $-2^{\circ} \mathrm{C}$ are likely for the photosymbiotic species if, by analogy with the recent, they calcified in a low-pH microenvironment. If precise absolute temperatures are critical in a particular study, it would be prudent to use more than one equation in order to express the 
uncertainty associated with the choice of equation.

\section{Regional and temporal variations in $\delta^{18} \mathbf{O}_{\text {sw }}$}

The most significant complicating factor of using $\delta^{18} \mathrm{O}_{\mathrm{cc}}$ as a paleotemperature indicator is, of course, that it depends on knowing $\delta^{18} \mathrm{O}_{\mathrm{sw}}$ (Urey, 1947). However, this can also be viewed positively because if temperature is known, assumed, or determined (for example, by using another proxy), the method can be used in reverse to investigate regional variations in $\delta^{18} \mathrm{O}_{\mathrm{sw}}$, or to track the growth and decay of ice sheets through time. The $\delta^{18} \mathrm{O}$ of seawater can be thought of as reflecting two principal factors: 1) interregional variability that exists at any one time; and 2) the mean value of $\delta^{18} \mathrm{O}_{\mathrm{sw}}$ for the oceans as a whole, which can change over geological time.

The $\delta^{18} \mathrm{O}$ of bottom waters depends on the source area or areas for that water and its history of advection: the transport, mixing, upwelling, and downwelling of ocean currents (Rohling and Cooke, 1999). Consequently, the $\delta^{18} \mathrm{O}$ of epifaunal benthic foraminifera can be used (along with several other geochemical tools) to fingerprint deep water masses (Broecker and Peng, 1982). One especially important process that oxygen isotopes can help identify is sea-ice formation, which expels dense brines with strongly depleted $\delta^{18} \mathrm{O}$ values. The volume and distribution of such brines influences patterns of deep-water formation and is of potential significance in influencing the global thermohaline circulation of the oceans (Dokken and Jansen, 1999). The influence of brine formation on bottom-water $\delta^{18} \mathrm{O}$, as reflected in benthic foraminiferal data, is especially marked in enclosed basins such as the Weddell Sea in the Southern Hemisphere and the Barents and Nordic seas in the Northern Hemisphere (e.g., Vidal et al., 1998; Mackensen, 2001; Rasmussen and Thomsen, 2009).

The principal factor governing the regional $\delta^{18} \mathrm{O}$ of modern surface seawater is the local evaporation-precipitation $(E-P)$ balance. Because the salinity of seawater also depends on $E-P$, the two are often correlated, and the variability is sometimes referred to as a salinity effect on $\delta^{18} \mathrm{O}_{\text {sw. }}$. This is clearly only shorthand, however, because the $\delta^{18} \mathrm{O}$ of precipitation varies systematically with latitude (which changes the slope of the correlation; Craig, 1965), and additional variability is caused by factors such as river waters flowing into the ocean, iceberg melting, the local climate regime, and advection (see Rohling and
Cooke, 1999, for review). Despite this, within certain geographic regions, the relationship between surface $\delta^{18} \mathrm{O}_{\mathrm{sw}}$ and salinity is reasonably close, and a set of regional equations have been proposed (LeGrande and Schmidt, 2006).

The variability of $E-P$ is exemplified with reference to the Hadley circulation of the atmosphere. In general, $E-P$ is negative in the equatorial regions because maximum solar insolation causes air masses to rise. Adiabatic expansion of the rising air masses promotes heavy precipitation. Conversely, the descending limbs of the Hadley cells at $\sim 30^{\circ} \mathrm{N}$ and $\mathrm{S}$ latitude are very dry, causing local $E-P$ to be positive in these regions. As the trade winds flow back towards the equatorial low pressure, they pick up moisture from the ocean surface once again, only to dump it in the Intertropical Convergence Zone (ITCZ). On an even broader scale, the global transport of water vapor from the tropics toward the poles (with condensation continually favoring the removal of ${ }^{18} \mathrm{O}$ ) means that the $\delta^{18} \mathrm{O}$ of precipitation and seawater tends to become progressively more depleted at high latitudes. The regional $\delta^{18} \mathrm{O}_{\text {sw }}$ pattern is also strongly affected by global thermohaline circulation. For example, deep-water formation at the present time is focused around Antarctica and the high-latitude North Atlantic. There is a compensatory net flow of surface water from the Pacific to the Atlantic, which evaporates along the way, becoming saltier as it does so. This, in combination with a net vapor transport from the Atlantic to Pacific via the trade winds, means that, in general, the $\delta^{18} \mathrm{O}_{\text {sw }}$ of Atlantic surface water is considerably more enriched than the $\delta^{18} \mathrm{O}_{\mathrm{sw}}$ of the Pacific and Indian oceans at similar latitudes (Broecker, 1989; Schmidt et al., 1999).

The modern variability of surface ocean $\delta^{18} \mathrm{O}_{\mathrm{sw}}$ is such that most places are within about $0.5 \%$ of VSMOW, but the total range in open ocean waters is from about $-1.5 \%$ to $+1.5 \%$, with even greater variation in semi-enclosed basins such as the Mediterranean, Baltic, and Red seas (Schmidt, 1999; Schmidt et al., 1999; Bigg and Rohling, 2000, LeGrande and Schmidt, 2006). Note that a $3 \%$ range corresponds to a temperature equivalent of over $10^{\circ} \mathrm{C}$ in the paleotemperature equations, therefore, this is an important issue if one seeks to establish patterns of sea-surface temperature distributions in the geological past. Zachos et al. (1994) proposed a correction factor for latitudinal variations in $\delta^{18} \mathrm{O}_{\mathrm{sw}}$ for use in global compilations of past SST variation by fitting a polynomial function through modern 
Southern Hemisphere $\delta^{18} \mathrm{O}_{\text {sw }}$ data:

$\delta^{18} \mathrm{O}_{\mathrm{sw}}=0.576+0.041 x-0.0017 x^{2}+0.0000135 x^{3}$

where $x$ is absolute latitude ( $\mathrm{N}$ or $\mathrm{S})$ in the range $0-70^{\circ}$ (Figure 6). Note that this equation is quite deliberately a blunt tool: it is based only on data from the Southern Hemisphere, but is intended for use in both hemispheres and in deep geological time. It avoids the poles because of the unknown influence of ice (or lack of it). The idea is that it can be used in non-analogue conditions, such as the Paleogene oceans, when different global circulation patterns may have operated and a net flow of surface water to the Atlantic cannot be assumed.

The Zachos et al. (1994) latitude correction continues to find favor in deep-time paleoclimate studies (e.g., Hollis et al., 2012). It is, however, less appropriate for assessing sites influenced by boundary currents where the latitudinal relationship barely applies, and it was never intended for marginal or semi-isolated basins. Moreover, the fundamental relationship between $\delta^{18} \mathrm{O}_{\mathrm{sw}}$ and latitude is very likely to have changed through time, especially in the transition from a greenhouse to icehouse climate in the early Oligocene (Bice et al., 2000; Huber et al., 2003). A promising alternative is to extract surface $\delta^{18} \mathrm{O}_{\text {sw }}$ values for study sites from General Circulation Models. Such models use imposed paleogeographies and greenhouse gas forcings to simulate past atmospheric and oceanic circulation patterns. In modern isotope-enabled GCMs, the oxygen isotope fractionations are also modeled (Schmidt, 1999; Huber et al., 2003; Tindall et al., 2010; Roberts et al., 2011). However, as pointed out by Roberts et al. (2011) and Hollis et al. (in press), these values are strongly dependent on the particular simulation used.

The mean value of $\delta^{18} \mathrm{O}_{\text {sw }}$ varies through geological time mainly because of changes in the amount of continental ice, and changes in the rock cycle, principally chemical weathering of rocks and the interaction of seafloor basalts and seawater. The rock-cycle processes are slow, but could become significant at the $\sim 1 \%$ level over timescales of $10^{8}$ years or more (Veizer et al., 1999; Wallmann, 2001; Jaffrés et al., 2007). Much evidence exists, for example, that $\delta^{18} \mathrm{O}$ values of early Paleozoic brachiopods are significantly depleted by several parts per mil compared to comparable Mesozoic and Cenozoic fossils, and a very long-term change in $\delta^{18} \mathrm{O}_{\text {sw }}$ may be partly

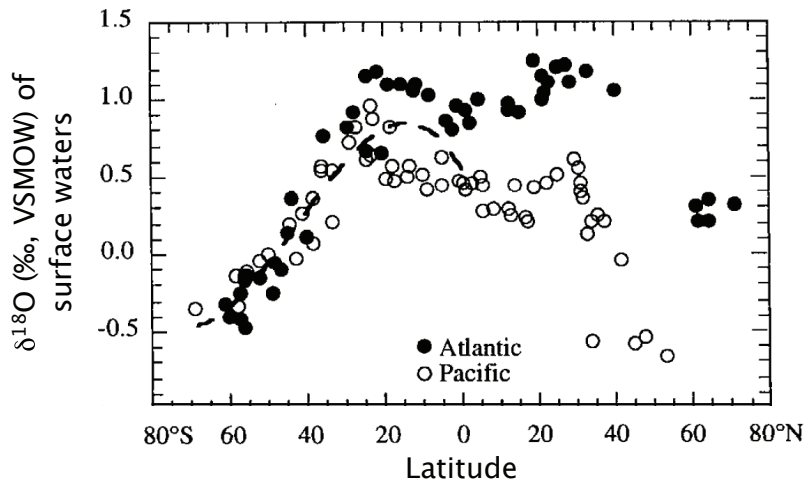

FIGURE 6.-Correcting for latitude in paleoapplications: Modern surface $\delta^{18} \mathrm{O}_{\mathrm{sw}}$ (VSMOW) plotted against latitude for the Atlantic and Pacific Oceans (data of Broecker, 1989). The dashed line is the Zachos et al. (1994) polynomial function for use in paleoclimate studies, which averages the southern hemisphere data (see text). Modified from Crowley and Zachos (2000).

responsible (e.g. Veizer et al., 1997, 2000; Prokoph et al., 2008; also see Grossman, 2010, 2012). However, there is much less difference between Mesozoic and Cenozoic values, suggesting that the effect is either small or negligible for at least the last $\sim 200$ m.y.. (Hudson and Anderson, 1989; Veizer et al., 1997; Jaffrés et al., 2007). Even so, do not forget that even a $0.5 \%$ o difference in, say, mid-Cretaceous average $\delta^{18} \mathrm{O}_{\mathrm{sw}}$ (which could be hard to detect given the current data) would cause a systematic bias of about two degrees.

The calculation of the influence of global ice volume on average $\delta^{18} \mathrm{O}_{\text {sw }}$ depends on knowing how much continental ice was on the planet at a given time, and what its mean $\delta^{18} \mathrm{O}$ was (meteoric waters also have a slight effect on this budget). Shackleton and Kennett (1975) made a simple (and much quoted) estimate of the isotopic ratio of an ice-free world (Table 2). Some subtleties in this calculation should be clarified. The $\delta^{18} \mathrm{O}_{\mathrm{sw}}$ figure of $-0.28 \%$ is from Craig (1965), and it consists of two components: the conversion factor from SMOW to PDB of $-0.20 \%$ (as then understood) and an additional $-0.08 \%$ to account for the difference between the whole ocean (i.e., deep water included) and the SMOW standard. The value for the ice-volume effect on its own (the transition from the modern world to a world with no ice) is almost exactly $-1.0 \%$ by this calculation (see also Zachos et al., 1994). Hence for the paleotemperature equation of Shackleton (1974), the 
TABLE 2.- Shackleton and Kennett (1975)'s estimate of the isotopic ratio of an ice-free world. * Note that the actual calculation yields -1.196 , which is rounded to -1.2 .

\begin{tabular}{lll}
\hline Body & Volume $\left(\mathbf{k m}^{3}\right)$ & $\begin{array}{l}\boldsymbol{\delta}^{\mathbf{1 8}} \mathbf{O \%} \\
\text { (PDB) }\end{array}$ \\
\hline Modern ocean & $1,360,000,000$ & -0.28 \\
Antarctica & $24,000,000$ & -50 \\
Other ice & $2,600,000$ & -30 \\
$\begin{array}{l}\text { Preglacial } \\
\text { ocean }\end{array}$ & $1,386,600,000$ & $-1.2 *$ \\
\hline
\end{tabular}

appropriate value for the $\delta^{18} \mathrm{O}_{\mathrm{sw}}$ term (including the VPDB conversion) is $-1.2 \%$ VSMOW for an ice-free world, whereas for the Erez and Luz (1984) equation, it would be $-1.22 \%$ VSMOW, and for Kim and O'Neil (1997) it would be $-1.27 \%$ VSMOW (see the explanation of appropriate VSMOW to VPDB conversions, above).

The above calculation explains the values for an ice-free world that commonly are encountered in the literature (which are sometimes quoted with the VPDB correction included and sometimes not). However, a more sophisticated approach has now been taken by modeling the growth of present-day ice sheets through their climate history and allowing the $\delta^{18} \mathrm{O}$ of precipitation (which is now ice buried in the ice sheets) to vary with past climate. Initial calculations indicated that melting of the East Antarctic, West Antarctic, and Greenland ice sheets would respectively contribute $-0.91 \%$, $-0.13 \%$, and $-0.07 \%$ o to ocean, totaling $-1.11 \pm 0.03 \%$ o for an ice-free ocean (L'Homme et al., 2005). However, it should be noted that Cramer et al. (2011) recalculated the total ice-volume effect using the ice-sheet compositions of L'Homme et al. (2005) and updated values for the mass of the oceans and ice sheets, resulting in an estimate of just $-0.89 \%$. At the time of writing, this discrepancy seems unresolved. In either case, for use in a paleotemperature equation, the appropriate VSMOW to VPDB conversion term needs to be added (see Table 1).

\section{Depth habitats of planktonic foraminifera}

As Emiliani (1954a) discovered, planktonic foraminifera are adapted to live across a range of depth habitats and, therefore, across a wide range of temperatures. Moreover, at maturity, they typically descend to a particular depth in the ocean where they reproduce. The style of calcification often changes markedly during reproduction (gametogenesis), when a thick layer of additional calcite is often laid down (called gametogenic calcite; Bé, 1980; Duplessy et al., 1981). If whole tests are analyzed, this depth migration will be averaged out (Lohmann, 1995). As the volume of gametogenic calcite can be $>50 \%$ of the test, temperatures can be biased very easily to the cold end-member in species that produce a thick calcite crust.

A recent example of depth stratification of species is shown in Figure 7 (from Birch et al., submitted). Here, several species of foraminifera from a single core-top sample were analyzed for $\delta^{18} \mathrm{O}$, from which a temperature was determined. Estimates of their calcification depths were then made by fitting the temperature estimates against the measured water-column temperature profile. Also shown on the figure are vertical profiles of oxygen concentrations and fluorescence (a measure of chlorophyll concentrations). Bearing in mind that many species of planktonic foraminifera occur as juveniles in the surface ocean and descend during their life cycle, the foraminifera divide into four main ecological groups: 1) those living exclusively in the surface mixed layer $(0-$ $40 \mathrm{~m}$ at this site); 2) those living and calcifying mostly in the upper thermocline where peak primary production takes place $(40-100 \mathrm{~m}) ; 3)$ those calcifying at depth around the shallow oxygen minimum zone (100-200 m); and 4) a single, deeper-dwelling species living in sub-thermocline intermediate water. Groups 1 and 2 are composed mainly of carnivores and photosymbiotic species whereas Groups 3 and 4 survive by feeding on sinking phytodetritus (e.g., Hemleben et al., 1989). These results are broadly consistent with many other geochemical and field studies of these species, including depth-stratified plankton nets and sediment traps (Fairbanks et al., 1982; Curry et al., 1983; Hemleben et al., 1989; Mulitza et al., 1997, 1999; Faul et al., 2000; Spero et al., 2003; Mohtadi et al., 2011).

Figure 7 shows that most species calcify in subsurface waters. The total reconstructed temperature range of this particular assemblage varies from about $29^{\circ} \mathrm{C}$ to $8^{\circ} \mathrm{C}$ at depth (Birch et al., submitted). Hence, if the aim is to reconstruct sea surface temperature (SST), it is necessary to pick a species that lives its entire life cycle in the 


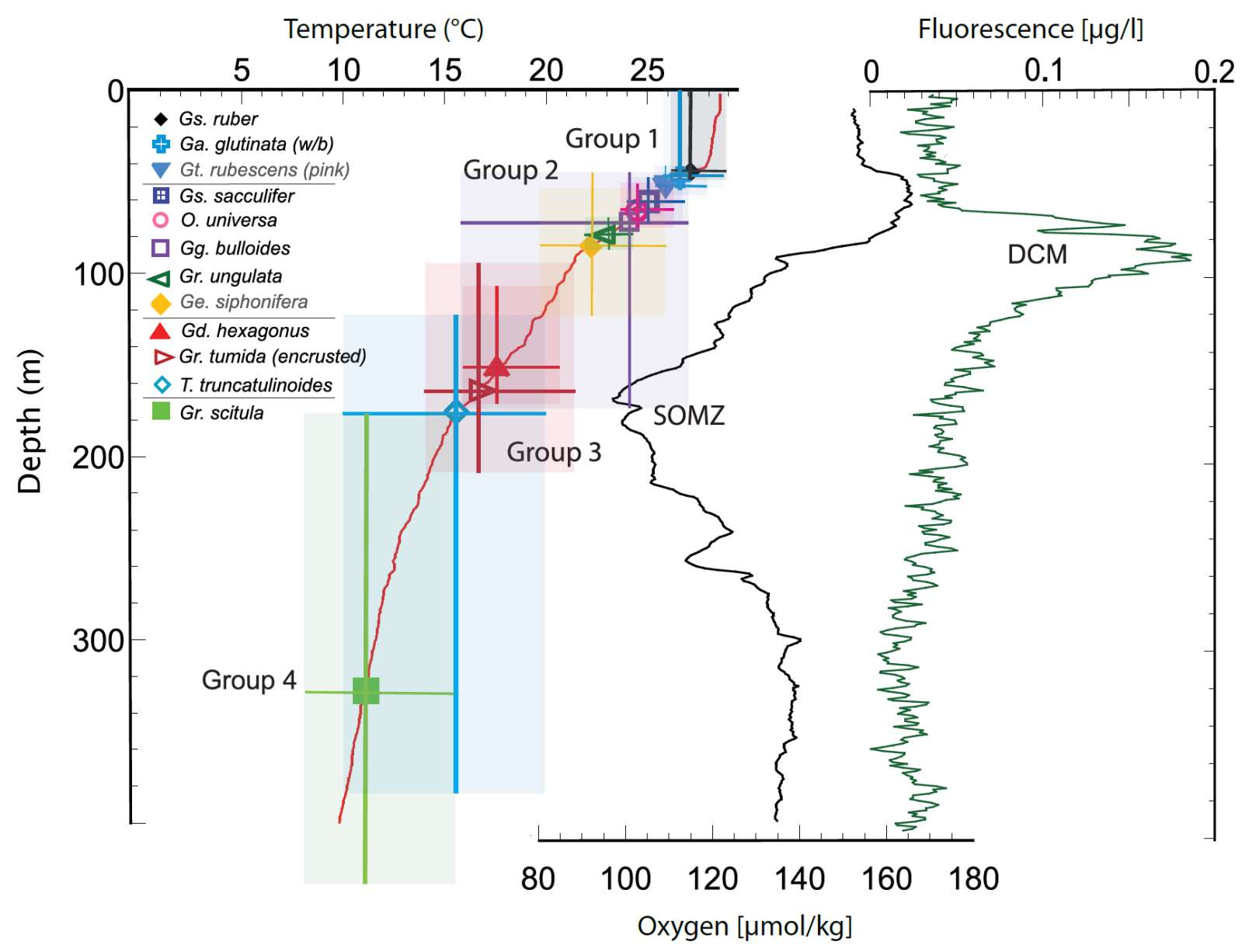

FIGURE 7.- Reconstructing the water column:depth habitats of a modern tropical assemblage of planktonic foraminifera. A core-top sample of 13 species had their mean depths of calcification reconstructed by fitting their $\delta^{18} \mathrm{O}$ to the locally measured temperature profile (red line). Also shown is the oxygen concentration (related to the balance between photosynthesis and respiration) and fluorescence (related to the chlorophyll concentration). Horizontal bars indicate the range of measured paleotemperature for each species; vertical bars indicate the corresponding depth range. Group 1 are species that calcify in the surface mixed layer and approximate the sea surface temperature. Group 2 live at maximum biological production corresponding to the broad peak in oxygen. Group 3 are oxygen-minimum specialists and Group 4 (just one species) calcifies in deep water.

mixed layer, the best known of which is Globigerinoides ruber. Other species (including the commonly studied $G$. sacculifer and Orbulina universa) yield slightly more enriched $\delta^{18} \mathrm{O}$ values even though they are sometimes referred to as surface dwellers in the literature. They do occur in surface waters, but many, if not all of the individuals descend to reproduce in the upper thermocline where gametogenic calcite is added to the test.

Genetic work has shown that the traditional species of planktonic foraminifera as recognized by their distinctive morphological features encompass a number of genotypes (see recent compilations by Darling and Wade, 2008; Ujiié and
Lipps, 2009; and Aurahs et al., 2009). To what extent these genotypes represent varieties or species in the biological sense is not yet entirely clear, although some genotypes do correspond to morphologically distinct types and almost certainly do represent separate species with substantial divergence times in the geologic past (e.g., Huber et al., 1997; de Vargas et al., 1999). The presence of unrecognized cryptic species in paleoceanographic samples could affect the accuracy of the $\delta^{18} \mathrm{O}$ proxy, especially if those species inhabited different environmental conditions (Wang, 2000; Kucera and Darling, 2002). Despite potential problems of distinguishing very closely related species, the rich fossil record of planktonic 


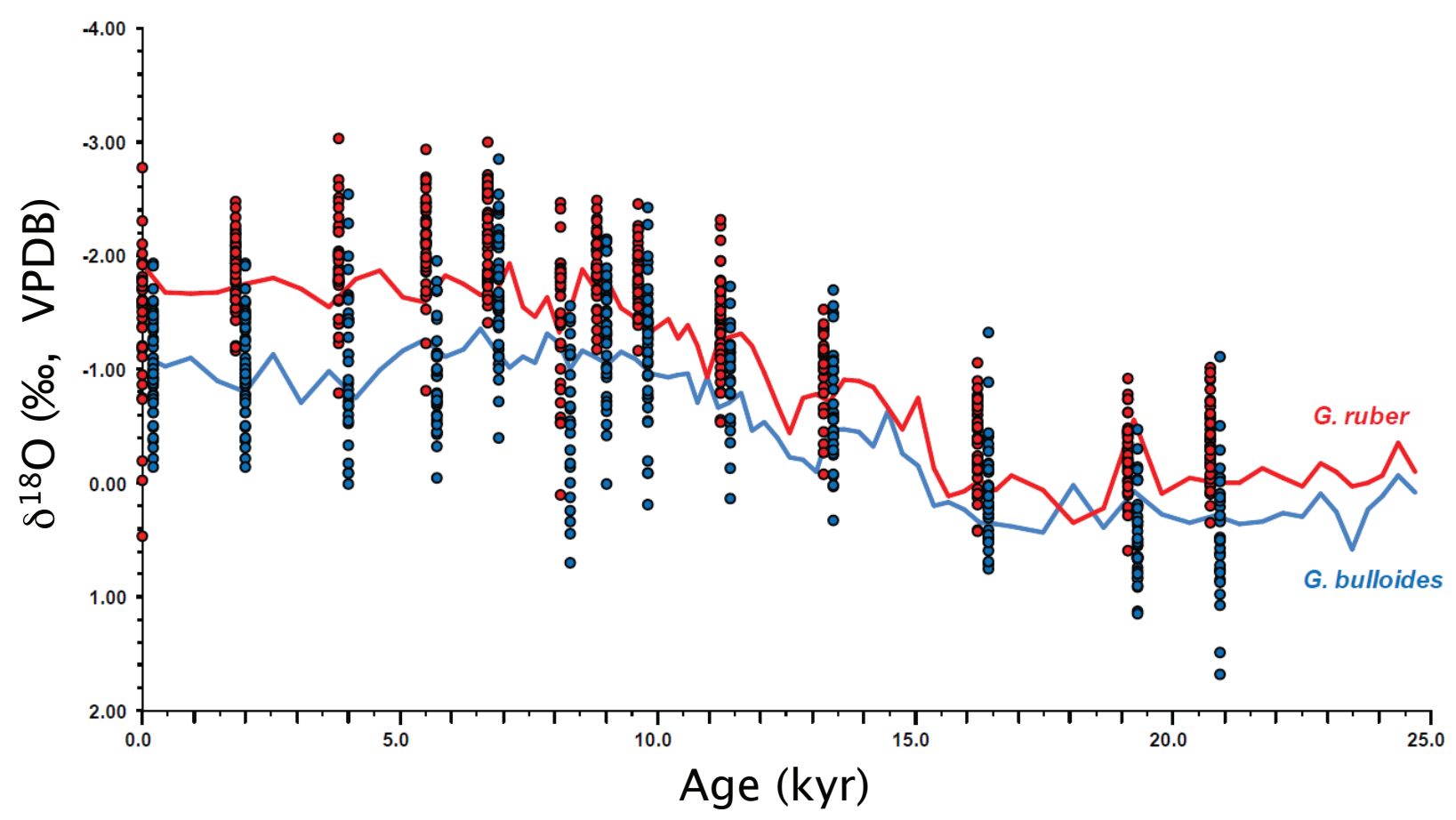

FIGURE 8.- Oxygen isotope ratios of individual tests of the planktonic foraminifera Globigerinoides ruber (red circles) and Globigerina bulloides (blue circles; slightly offset to left to aid visibility) in a core that spans the last deglaciation. The single specimen results are plotted against multi-specimen records from the same core by Ivanova (2000) (solid lines). Note the wide range of $\delta^{18} \mathrm{O}$ values given by individual tests. (Modified from Ganssen et al., 2011.)

foraminifera and their use in biostratigraphy means that it is possible to reconstruct their evolutionary history with impressive detail (see Aze et al., 2011, for a recent review). Individual morphospecies typically persist in the record for several millions of years (benthic foraminifera persist for longer - typically tens of millions of years). The more common species tend to be present continuously in core samples, making them ideal for the construction of geochemical time series.

\section{Single vs. multispecimen analysis}

Early work on the $\delta^{18} \mathrm{O}$ of foraminiferal tests required many specimens of the same species to be combined to provide enough calcite for a single analysis. Initially, in order to provide about 5 mg of sample, several hundred tests were needed (Emiliani 1955; Shackleton, 1967; Olausson, 1996). Now, instrumental improvements mean that typically, just one or a few specimens are needed depending on species and size fraction. Combining specimens averages out much of the variability between individuals that might result, for example, from the fact that different individu- als of the same species calcified at different depths in the water column or different times of year. For many applications, particularly timeseries work, this is desirable because it helps eliminate noise from seasonal and inter-annual variation, and provides a clearer picture of longterm secular changes in the species average value that might result from climate or global icevolume variations. However, it also destroys information of inter-individual variability that might also be of interest, such as determining seasonal temperature ranges. Unsurprisingly, this is more of an issue with planktonic than it is with benthic foraminifera, which occupy a much more constant habitat.

Some mass spectrometers are sufficiently sensitive to measure individual planktonic foraminifer tests. The first to achieve this were Killingley et al. (1981), who measured large-sized tests of Orbulina universa and two other species through a box core in the equatorial Pacific Ocean, spanning the Holocene and Last Glacial Maximum. They found inter-specimen variability of about $2 \%$, which is about twice that which could result 


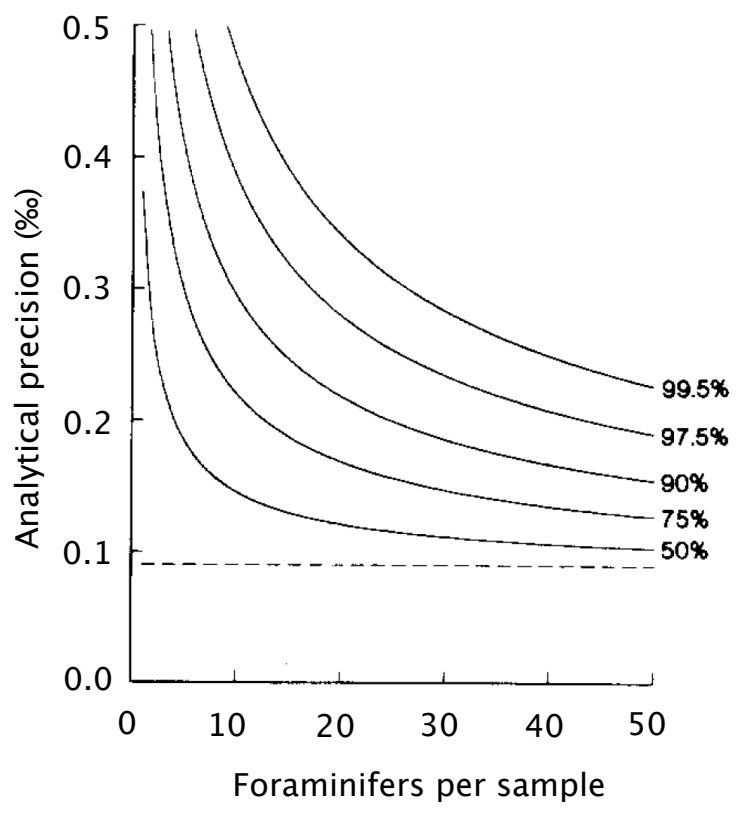

FIGURE 9.- How many foraminifera should one combine? Examples of precision: reliability sampling curves for $\delta^{18} \mathrm{O}$ based on the variability of single specimen data measurements from one species (Globigerinoides sacculifer, 355-420 $\mu \mathrm{m}$ ) at one location. Curves for other species, size fractions, and locations will differ, depending on their inherent variability (standard deviation) of the measurements. Various confidence levels are shown. The curves show that even if fifty tests are combined in one sample, the $50 \%$ reproducibility level is still less precise than machine precision (dashed line). (Modified and relabeled from Schiffelbein and Hills, 1984.)

from seasonal temperature change at the site, so they suggested that variability in individual depth habitats, and possibly vital effects, must be responsible for the spread of values. They also suggested that if an accurate species-average $\delta^{18} \mathrm{O}$ value was to be obtained, about 50 individuals would have to be combined. Similar results to Killingley et al. (1991) were obtained recently by Ganssen et al. (2011) for two species, and are reproduced here in Figure 8.

Schiffelbein and Hills (1984) statistically investigated the sampling issue to demonstrate how the number of specimens that are combined for one measurement relates to the precision of a measurement given the standard deviation found in a particular population. An example of one of their precision:reliability sampling curves is shown in Figure 9. It emphasizes that noise in multi-specimen records is more likely to be because of sampling than measurement, and that it is still desirable to combine $20+$ specimens for an analysis, even if the instrument can run just two or three. Schiffelbein and Hills (1984) calculated that to achieve a reproducibility of $0.1 \%$ at $90 \%$ confidence one would typically have to combine $>400$ tests.

Single-specimen results similar to those of Killingley et al. (1981) and Ganssen et al. (2011) have been obtained for a number of common species in various places. Some authors have successfully used inter-specimen variability to isolate environmental signals such as seasonal salinity and/or temperature variation (Tang and Stott, 1993; Ganssen et al., 2011; Friedrich et al., 2012a) and changes in the amplitude of the El Niño climate oscillation (Koutavas et al., 2006; Leduc et al., 2009). Single-specimen analyses are also useful for distinguishing tests that may have been reworked across major environmental shifts such as the last deglaciation (Killingley et al., 1981), Cretaceous/Paleogene boundary (Kaiho and Lamolda, 1999) and Paleocene/Eocene boundary (Kelly et al., 1996; Zachos et al., 2007).

\section{Diagenesis}

When he first proposed the oxygen isotope paleothermometer, Urey remarked: "We cannot expect that every fossil which has been or will be found on the surface of the earth can be tested by our methods for the temperature at which it lived. We do hope, however, to find a small fraction of such fossil remains preserved to such a degree that such measurements can be made" (Urey, 1946, p. 495-496). The initial focus of the Chicago group was on belemnites because it was thought that the heavily calcified rostra (or guards) would be protected from the worst diagenetic effects. However, as we have seen, when Emiliani began the systematic study of foraminiferal $\delta^{18} \mathrm{O}$, the results were very encouraging: species-specific offsets were found and related to habitat (Emiliani, 1954a), and a coherent signal could be extracted going back millions of years (Emiliani, 1954b). However, just because a signal can be extracted, it does not mean that it is preserved without alteration.

After death, planktonic foraminiferal tests sink through the water column until they either reach the sea floor or dissolve in corrosive bottom waters (Berger, 1971, 1979a; Hemleben et al., 1989). It is also possible that some dissolution occurs in the low $\mathrm{pH}$ waters of the oxygenminimum zone (Milliman et al., 1999; but see also Bissett et al., 2011, and Friedrich et al., 


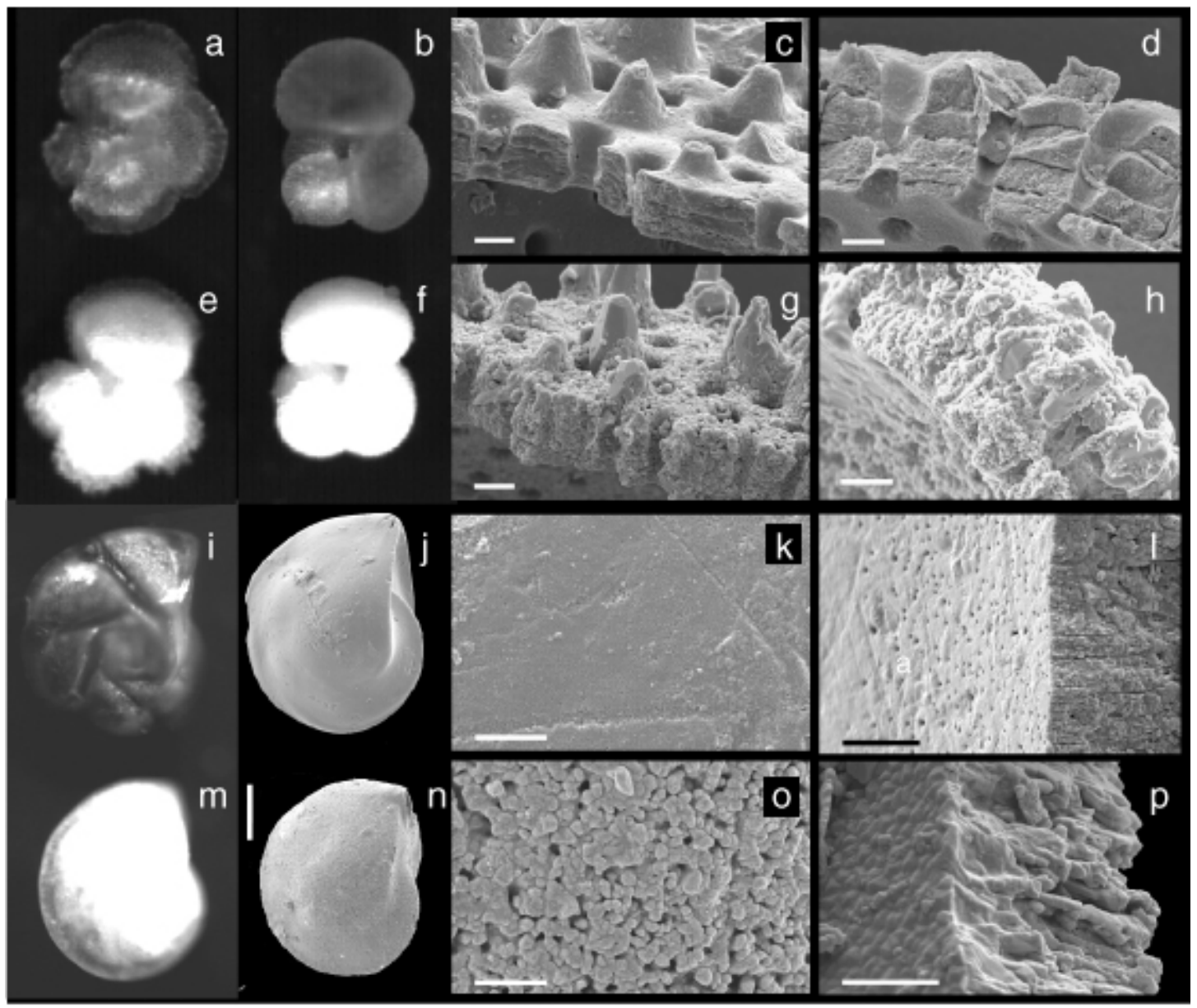

FIGURE 10.-Recrystallization textures. These images contrast well-preserved planktonic (a-d) and benthic (i-1) foraminifera under light microscope and SEM dissections versus recrystallized specimens of the same species (e-h, $\mathrm{m}-\mathrm{p}$ ). Diagenesis causes complete internal recrystallization of the test walls. (Modified from Pearson et al., 2007.)

2012a, who suggest water-column effects generally are minimal). Further dissolution in the sediment of both benthic and planktonic foraminiferal tests can be promoted by low $\mathrm{pH}$ associated with the aerobic mineralization of organic matter (Jahnke et al., 1997), or, for oxygen-deficient sediments, exposure to oxygen during storage of the cores themselves (Self-Trail and Seefelt, 2004). The external gametogenic calcite often is more resistant to dissolution, so tests can become hollowed out with the internal chamber wall dissolved away (Bé et al., 1975). If different phases of the foraminiferal calcite were produced at different times in the life cycle, such differential dissolution potentially could alter the isotopic ratios. This effect can be especially important if an isotopic record is produced from a site that shows varying dissolution intensities through time. Lohmann (1995) highlighted the importance of assessing the mass balance between chamber calcite and gametogenic crust when considering both the original habitat and the potential effects of dissolution.

Precipitation of calcite cements from pore waters is a frequently encountered problem. It can occur on the outside of a test, overgrowing surface features, or on the inside, commonly filling the test completely. If this happens during shallow burial, the cements are likely to have a more enriched $\delta^{18} \mathrm{O}$ than the original plankton tests, but if cements are formed at high temperatures after substantial burial, the opposite will be the case (Schrag, 1999). Diagenetic cements formed from percolating meteoric waters (which are often encountered in geological sections emplaced on land) also will tend to have depleted $\delta^{18} \mathrm{O}$, often by several parts per mil (e.g., Corfield et al., 1990). Clearly, foraminifer tests with substantial 


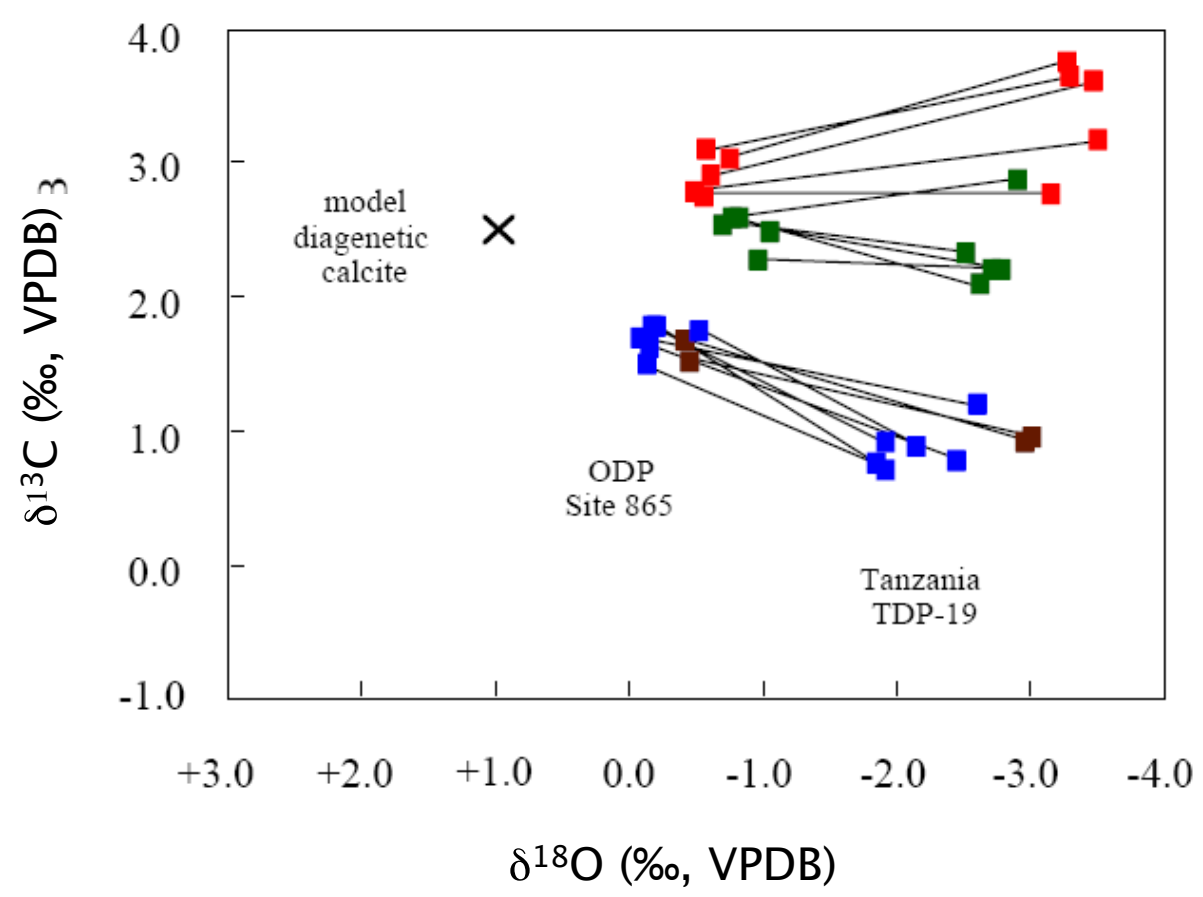

FIGURE 11.-Comparison of the $\delta^{18} \mathrm{O}$ and $\delta^{13} \mathrm{C}$ of a well-preserved middle Eocene assemblage of foraminifera from Tanzania (right) with a recrystallized assemblage of the same age from tropical Pacific drill core ODP Site 865 (centre). Species are divided into mixed layer, thermocline, lower thermocline and unknown habitats. Lines join data from the same species and size fraction. Data of the recrystallized assemblage converge on the expected composition of seafloor diagenetic calcite precipitated at $\sim 11^{\circ} \mathrm{C}$ with average $\delta^{13} \mathrm{C}$. Assuming the recrystallized assemblage started out with similar isotopic ratios to the well preserved foraminifera, the data suggests a $\sim 50-60 \%$ contribution of diagenetic $\mathrm{O}$ and $\mathrm{C}$ in the recrystallized tests (see text). $\mathrm{ODP}=$ Ocean Drilling Program; TDP =Tanzania Drilling Project. See Appendix 1 for data and further information.

diagenetic overgrowth and infilling are not suitable for extracting accurate paleoenvironmental information. Fortunately, such effects are usually plainly visible under the light microscopic and/or scanning electron microscope (SEM) (Pearson and Burgess, 2009).

Micron-scale recrystallization of tests, which occurs commonly during the shallow burial of deep-sea carbonate oozes, is more of a problem. The biogenic texture of most foraminifer tests is microgranular, with individual granules or plaques in the $\sim 0.1 \mu \mathrm{m}$ size range and having irregular shapes. However, this texture is commonly replaced entirely by larger, more-equant neomorphic calcite crystals in the $\sim 1 \mu \mathrm{m}$ range (Pearson et al., 2001). This wholesale recrystallization can cause very substantial alteration of the oxygen-isotope ratios (Pearson et al., 2001, 2007; Williams et al., 2004; Sexton et al., 2006). Perhaps because a component of the original isotopic signature remains after recrystallization, this problem was not fully appreciated for many years, so claims in the literature that foraminifera are well preserved cannot always be relied upon. Pearson and Burgess (2009) proposed the following criteria for recognizing exceptionally preserved tests: (1) tests should be reflective and translucent under reflective light, especially the smaller, thin-walled species; (2) when placed in water or oil, ultrafine features smaller than a micron should survive (e.g. spines, if originally present); (3) originally smooth parts of the test surface and interior should still be smooth on a submicron scale; and (4) the original submicron granular texture should be visible in cross-section when the test is broken.

These features are illustrated in Figure 10. It was originally hoped that benthic foraminifera might be less prone to recrystallization than planktonic forms because of their denser calcite microstructures (Pearson et al., 2001), but it seems that this is not the case (Sexton et al., 2006; Pearson et al., 2007; Figure 10). Unfortunately, recrystallization is nearly ubiquitous in deep-sea 
carbonate oozes and chalks of substantial geologic age (millions of years). On the other hand, well-preserved foraminifera generally are found in hemipelagic clays, where the low permeability presumably inhibits the recrystallization process (e.g., Norris and Wilson, 1998; Pearson et al., 2001; Wilson et al., 2002; Sexton et al., 2006; Pearson and Wade, 2009).

The effect of diagenetic recrystallization on the oxygen and carbon isotope ratios of planktonic foraminiferal assemblages is shown in Figure 11, which compares two assemblages of middle Eocene foraminifera, one well-preserved and the other recrystallized. This type of comparison, although never exact, suggests that recrystallized assemblages are partially homogenized in their isotope ratios, reducing interspecies differentials, and converging on the expected value for diagenetic calcite. Because the $\delta^{13} \mathrm{C}$ of diagenetic calcite is similar to an average value of the foraminifera, the absolute values do not change much. However, the oxygen isotope ratio of inorganic calcite on the sea floor is very different from the original planktonic values because of the colder temperatures, so the shift in $\delta^{18} \mathrm{O}$ is much more substantial. This point was made by Pearson et al. (2001, their fig. 4) in a similar diagram; data for Figure 11 and further details are given in the Appendix and online spreadsheet at $<$ http://paleosoc.org/shortcourse2012.html $>$. Note that although benthic foraminifera may be recrystallized, the effect on their $\delta^{18} \mathrm{O}$ values is probably relatively small because recrystallization usually occurs at or near the sediment/water interface at nearly the same temperature as the time of foraminifer shell growth. The impact of the diagenesis problem on the determination of tropical surface temperatures is discussed further below.

Kozdon et al. (2011) used an ion microprobe to analyze internal parts of the tests of recrystallized foraminifera and compared their values with whole-test measurements. Their results indicate that, although recrystallized, the internal parts of the test have exchanged less isotopically with their environment than the more outer parts of the test. This suggests that internal microprobe measurements may provide a better estimate of the original sea-surface temperature than the whole test. However, some degree of isotopic exchange cannot be ruled out even for the interior parts of recrystallized tests.

\section{PART 2: APPLICATIONS}

In this section, some of the main applications of oxygen isotope analyses of foraminifera are reviewed under three headings: 1) climate cycles and cyclostratigraphy, 2) deep-time benthic foraminiferal compilations, and 3) planktonic foraminiferal habitats and sea-surface temperatures. Happily, these three subject areas correspond to Emiliani's troika of papers that helped define the discipline of paleoceanography in its earliest days (Emiliani, 1954b, 1955, and 1954a, respectively).

\section{Climate cycles and cyclostratigraphy}

In the 1950s and 1960s, ongoing piston coring and Emiliani's deep coring strategy immediately paid dividends as isotopic investigations found the same series of $\delta^{18} \mathrm{O}$ stages in many different locations and extending further back into time. These cycles were similar to the warm/cold cycles that had been identified previously using foraminiferal assemblage data including the coiling directions and abundance of certain species (e.g., Ericson et al., 1956). The impact of these records was revolutionary, especially when one considers the extensive labors of land-based glacial geologists over the previous century had managed to identify only four major cycles of ice advance and retreat (see review by Imbrie and Imbrie, 1979). Profound discoveries are not always immediately accepted, and Emiliani's orbital interpretation of the $\delta^{18} \mathrm{O}$ variations and the ice ages was criticized on a variety of grounds (see Imbrie and Imbrie, 1979 , for review). It did, however, receive a substantial boost when Hays et al. (1976) studied two cores from the sub-Antarctic Indian Ocean and showed that down-hole records of $\delta^{18} \mathrm{O}$ in the planktonic foraminifer Globigerina bulloides were dominated by three main frequencies of variation. Crucially, the ratio of these three frequencies was the same as that between the Earth's eccentricity, obliquity, and precession cycles and, according to the age model, they also were very close to the expected durations. By allowing for subtle changes in sedimentation rates, the downhole records could be tuned to the expected frequencies, increasing the fit of the data and the inter-core correlation. The principle of astrochronology (dating by astronomical cycles) was thereby established.

As high-resolution $\delta^{18} \mathrm{O}$ records became available from many places, it became attractive to add them together and create composite stacks to average out local variability (e.g., Emiliani, 1978; Pisias et al., 1984; Imbrie and Imbrie, 1992). A long compilation of benthic foraminifer 


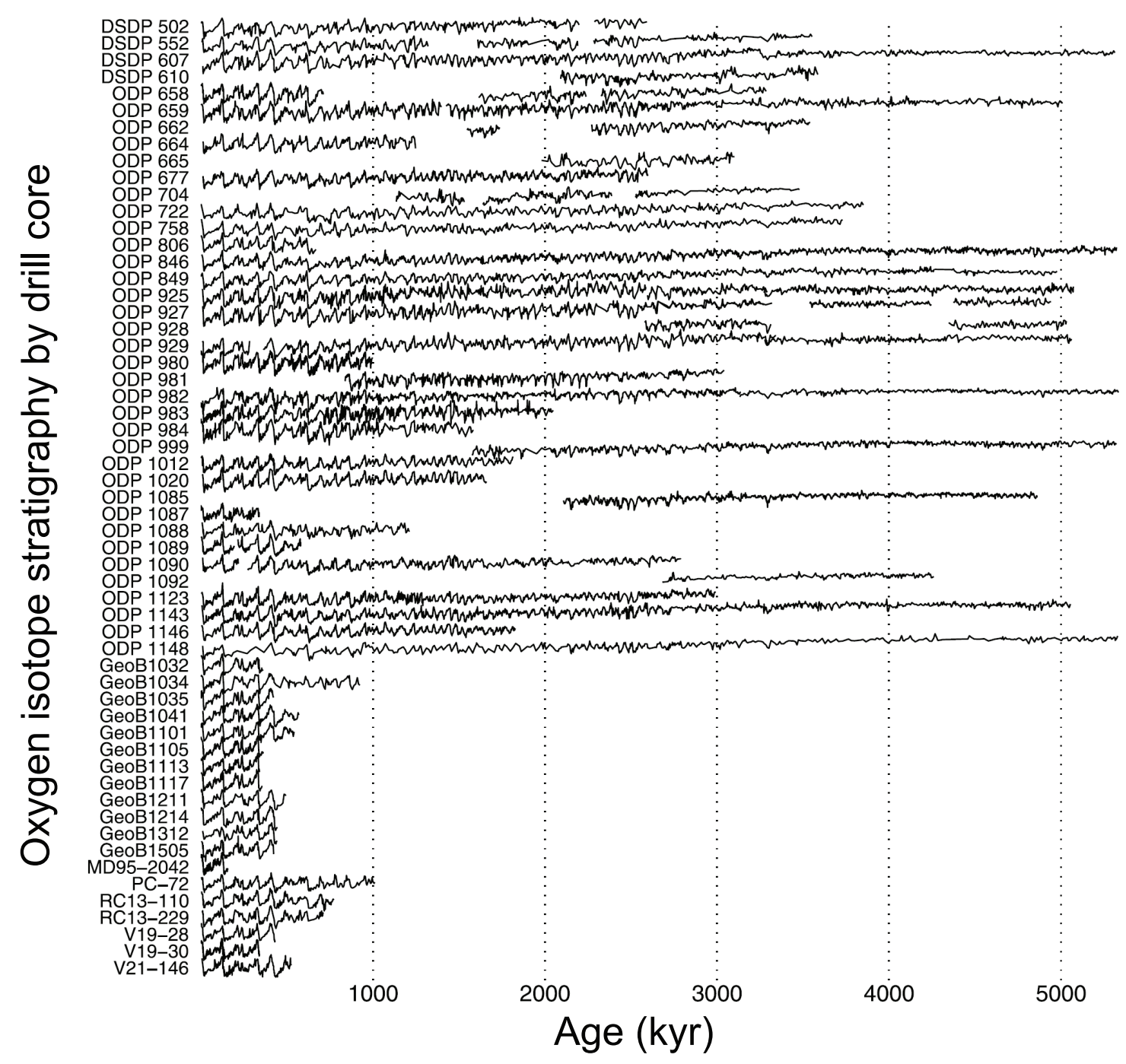

FIGURE 12.-Pacemakers of the ice ages: A stack of 57 globally distributed $\delta^{18} \mathrm{O}$ records from benthic foraminifera, correlated to a single timescale. Each record has negative (low ice, warm temperature) values to the top. The short cores are piston cores; the longer ones are Deep Sea Drilling Project and Ocean Drilling Program sites. The apparent curvature of the long records is real. (Modified from Liesiecki and Raymo, 2005)

$\delta^{18} \mathrm{O}$ data back to $5.3 \mathrm{Ma}$ was presented by Lisiecki and Raymo (2005), and was based on a large number of previous studies from laboratories around the world (see Lisiecki and Raymo, 2005, for references). Plotted alongside one another (Figure 12), the 57 globally distributed sites provide eloquent testimony to the ubiquitous influence of changes in the ice sheets and deep-sea temperatures over this period. The data indicate a long-term cooling/ice growth trend and an increase in the amplitude of the cycles towards the present day. Changes in the dominant frequency of variations are also clear, especially the intensification of $\sim 100 \mathrm{kyr}$ cyclicity over the past $\sim 1.2$ myr. This intensification is accompanied by the development of the characteristic saw-tooth pattern of the late Pleistocene glacial cycles, in which trends towards glacial intensification are suddenly and repeatedly terminated in abrupt deglaciations. An intriguing recent suggestion is that these late Pleistocene changes are the early signs or prelude of a future transition toward permanent glaciation of the Northern Hemisphere continental masses (Crowley and Hyde, 2008).

The $\delta^{18} \mathrm{O}$ cycles relate to changes in deep-sea temperature and ice volume (and hence sea level) (Cutler et al., 2003), and various authors have attempted to separate these effects (e.g., Shackle- 
ton, 2000; Raymo et al., 2006). The shape of the cycles is very different from the much smoother orbital forcing of climate (e.g., calculated solarinsolation curves). It is clear that although the orbital cycles set the frequency of variability, the climatic response is highly nonlinear. Much more than orbital theory is required to understand glacial cycles, which must be strongly influenced by feedbacks and thresholds internal to the Earth system. As Hays et al. (1976) originally put it, the orbital forcing is the 'pacemaker' of the ice ages, not the sole explanation for their pattern of onset and retreat, or their severity.

Oxygen-isotope stratigraphy has become an indispensable tool for stratigraphic correlation and timescale refinement, especially when combined in the same down-core records with magnetostratigraphy (e.g., Shackleton and Opdyke, 1973; Bassinot et al., 1994) and biostratigraphy (often based on the foraminifera themselves; see Wade et al., 2011, for review). In the 1960s, a different source of long-term (100 k.y.r. + ) climate archives was discovered in ice cores, the $\delta^{18} \mathrm{O}$ variations of which over the last glacial cycle were found to closely resemble the saw-tooth pattern already known from deep-sea foraminifer records (Dansgaard et al., 1969). Ice core records extend back almost to a million years (Luthi et al., 2008), revealing how intimately the global ice-volume fluctuations first observed in foraminiferal $\delta^{18} \mathrm{O}$ relate to atmospheric greenhouse-gas concentrations. Similar patterns also have been found in the $\delta^{18} \mathrm{O}$ of speleothems and compared to foraminifer records (e.g., Bar-Matthews at al., 2003). Highresolution records of climate variability from such archives has helped illuminate the geographic variability of climate change on land and in the oceans, notably the so-called 'bipolar seesaw' of Northern and Southern Hemisphere surface temperatures during the last deglaciation (Broecker, 1998; Barker et al., 2009). The causes and consequences of rapid climate change are being studied intensively, with an increasing emphasis on understanding spatial variability and climatic teleconnections (Cronin, 1999; Clark et al., 2002; Clement and Peterson, 2006).

This influence of orbital cyclicity on foraminiferal $\delta^{18} \mathrm{O}$ and $\delta^{13} \mathrm{C}$ records from deep-sea cores (and other parameters, such as $\mathrm{CaCO}_{3}$ content) extends back throughout the available record. For example, drilling on the Ceara Rise, an aseismic ridge in the tropical Atlantic, has produced moreor-less continuously cyclic records back to the early Oligocene, $\sim 30 \mathrm{Ma}$ (Shackleton et al., 1999;
Pälike et al., 2006). Other long records from the Pacific and South Atlantic have helped extend the coverage, and emphasized the importance of the long eccentricity cycle ( 405 k.y.r) on both $\delta^{18} \mathrm{O}$ and $\delta^{13} \mathrm{C}$ (Wade and Pälike, 2004; Westerhold et al., 2005). Combined with high-resolution biostratigraphy (Wade et al., 2011), such studies have allowed the calibration of the geological timescale (based on radiometric decay constants) to orbital chronology (based on gravitational physics of the solar system). The excellent fit between these geological chronometers validates both approaches to geochronology with great precision. Although chaotic interactions mean that the solutions for past orbital dynamics (e.g., interactions between precession, obliquity, and eccentricity) cannot be 'retrodicted' beyond about $40 \mathrm{Ma}$ (Laskar, 1999; Laskar et al., 2010), the geological records themselves can help reveal what those interactions were (Pälike et al., 2004).

\section{Deep-time benthic compilations}

When Emiliani (1954b) compared the first $\delta^{18} \mathrm{O}$ paleotemperatures of Oligocene, Miocene, and Pliocene foraminifera (see above, Figure 2) he relied on cores from the Albatross expedition that happened to sample sediment of those ages. He remarked: "It is unfortunate that more paleotemperature data from the ocean bottom are not available, particularly from the Eocene, Upper Miocene, and Lower Pliocene. The type of material that is needed, however, makes rather remote the probability of securing additional, suitable samples in the near future" (Emiliani, 1954b, p. 855). Systematic ocean drilling would eventually change that!

DSDP Legs 6 and 17 produced several long drill sites from the tropical Pacific Ocean extending as far back as the late Cretaceous. Douglas and Savin $(1971,1973)$ analyzed benthic and planktonic foraminifera at intervals from the Cretaceous through Pleistocene, and found a longterm increase in $\delta^{18} \mathrm{O}$ that they interpreted as a cooling trend. They also noted the inherent uncertainty associated with likely changes in the oxygen isotope ratio of seawater, which they assumed to be constant for the sake of calculation.

Shackleton and Kennett (1975) produced a somewhat higher resolution record from the highlatitude Campbell Plateau south of New Zealand and, as seen above (Table 2), took a more sophisticated approach to calculating the oxygen isotope ratio of seawater in an ice-free world. Their benthic isotope record shows a long-term cooling 


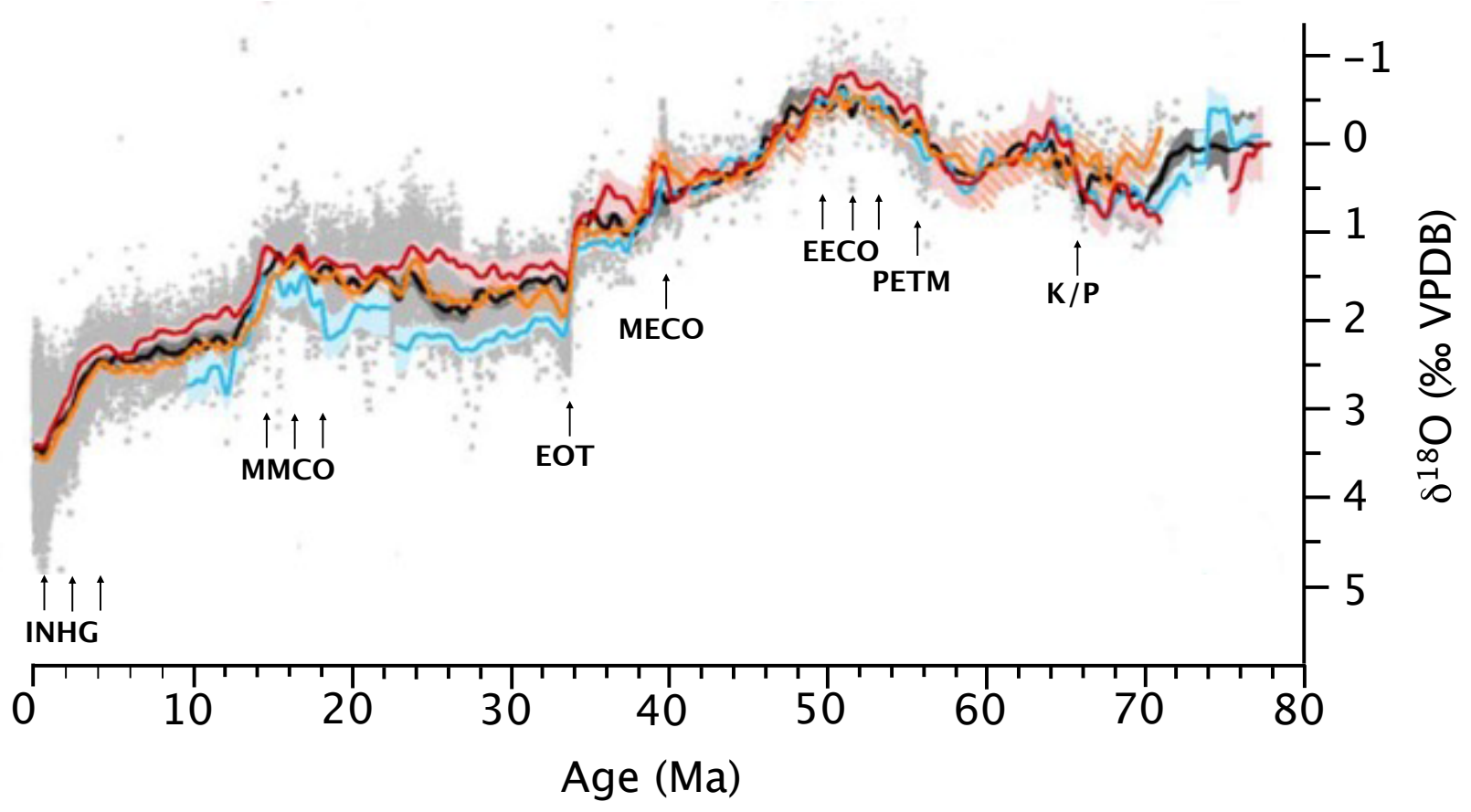

FIGURE 13.-The big stack: Compilation of deep-sea benthic $\delta^{18} \mathrm{O}$ values obtained by laboratories worldwide for the last 80 m. yr., normalized to Cibicidoides (see text). Black: global mean; blue: southern ocean; orange: Pacific; red: Atlantic. $\mathrm{INHG}=$ Intensification of Northern Hemisphere Glaciation; $\mathrm{MMCO}=$ Middle Miocene Climate Optimum; EOT $=$ Eocene-Oligocene transition; $\mathrm{MECO}=$ Middle Eocene Climate Optimum; EECO = Early Eocene Climate Optimum; PETM = Paleocene/Eocene Thermal Maximum; K/P = Cretaceous / Paleogene boundary. Note that the timescale of the Lisiecki and Raymo (2004) stack (Figure 12) corresponds to the last 5 myr. of this record. (Modified from Cramer et al., 2009, with acronyms added.) Trend lines represent different oceans.

trend from the late Paleocene to the Plio-Pleistocene. Shackleton and Kennett (1975) resolved several additional features, such as an early Eocene warming and sharp steps towards more positive values in the early Oligocene and middle Miocene. The early Oligocene $\delta^{18} \mathrm{O}$ shift to more enriched values was interpreted as due to cooling, not ice growth, because the bottom-water temperature was deemed too warm to be compatible with an ice cap in the early Oligocene. Instead, Shackleton and Kennett (1975) suggested that the Antarctic ice cap grew between the middle and late Miocene - a conclusion that has subsequently been challenged, as is discussed further below. More data were published by Savin et al. (1975), who independently reached similar general conclusions. Data from these early records were augmented and synthesized by Savin (1977).

As isotope laboratories proliferated and a wider community became involved in deep-sea drilling, data sets expanded, a process that continues to the present day. Significant compilations of
Cenozoic benthic foraminiferal isotope data were presented by Miller et al. (1987), Zachos et al. (2001, 2008), and Cramer et al. (2009), and for the Cretaceous, by Grossman (2010) and Friedrich et al. (2012b). When comparing these compilations, it is important to appreciate that they include different correction factors for vital-effect fractionations of some benthic foraminiferal genera (see discussion above). The recent Cramer et al. $(2009,2011)$ and Friedrich et al. (2012b) compilations also differ from earlier versions by calculating separate trends for different ocean basins in order to distinguish the influences of source waters with different temperatures (an effect that becomes very noticeable after the Eocene-Oligocene transition; Figure 13, and in the Cretaceous, for which see Friedrich et al., 2012b).

The deep-sea benthic foraminiferal oxygen isotope stack is the best record we have for trends in climate since the Early Cretaceous. It illustrates how profoundly the temperature and global ice volume must have changed over this period. The 


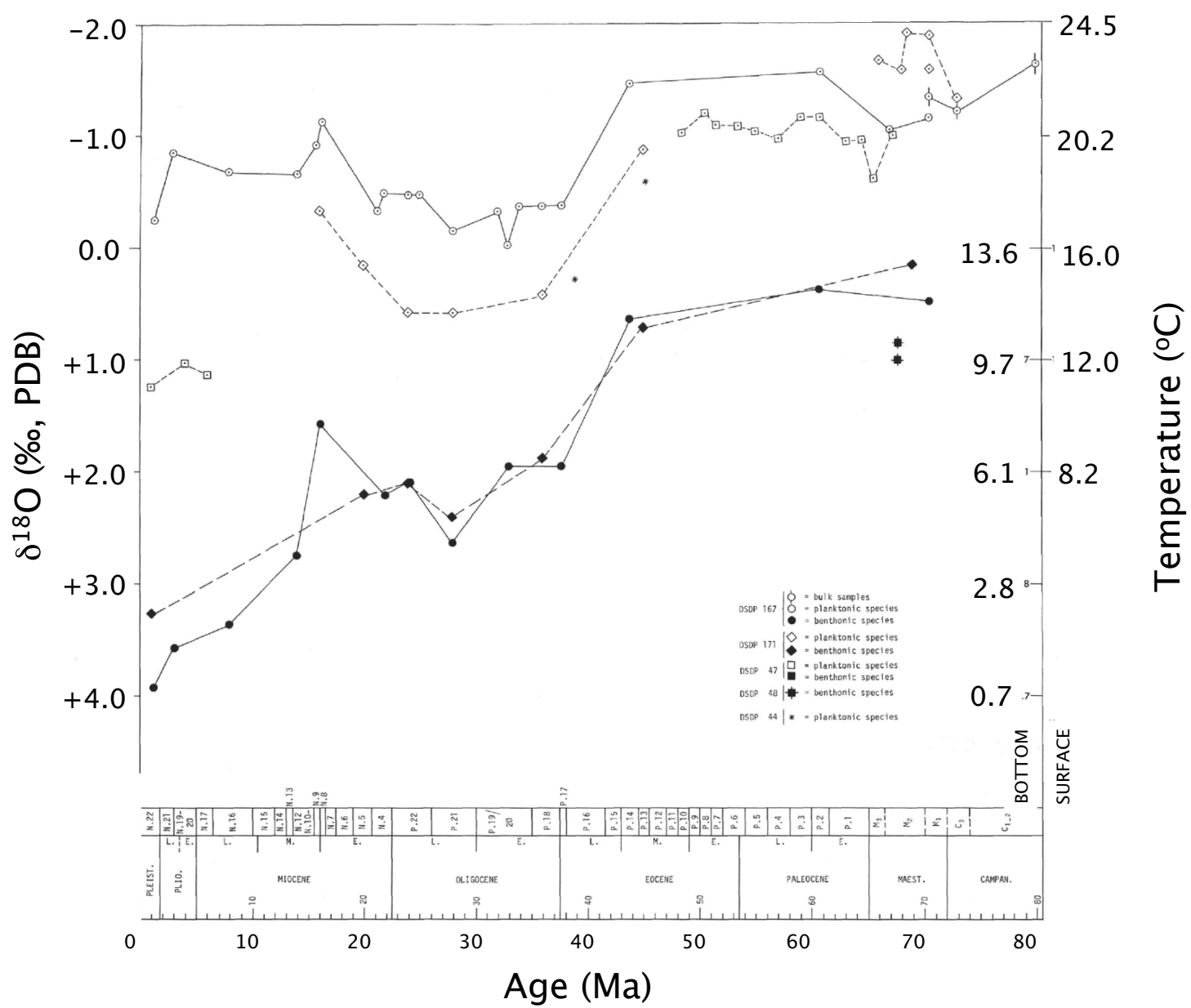

FIGURE 14.-The first glimpse of deep climate history: oxygen isotope paleotemperature estimates for various planktonic (open symbols) and benthic (filled symbols) foraminifera from DSDP Legs 6 and 17, tropical Pacific Ocean (From Douglas and Savin, 1973, axes relabeled for clarity). Note the different 'bottom' and 'surface' temperature scales.

current consensus is that the planet was close to being ice-free in the early Eocene, and seafloor temperatures were about $14^{\circ} \mathrm{C}$, compared to only $2-3^{\circ} \mathrm{C}$ today (Cramer et al., 2011). Global temperatures may have been even higher in the midCretaceous. The long-term Cenozoic climate variability was memorably described by Zachos et al. (2001) as consisting of trends, rhythms, and aberrations - the trends include the warming in the Paleocene and coolings in the Eocene, Oligocene, and Miocene to Recent. The aberrations can be divided into transient events such as the Paleocene/Eocene Thermal Maximum, and switches, such as the Eocene-Oligocene transition. The rhythms are the orbital cycles which, although ever-present, are too short in wavelength to be individually resolved on Figure 13 (but see Figure 12 for comparison of the last $5 \mathrm{my}$.).

\section{Planktonic habitats and paleo sea-surface temperatures}

The benthic foraminiferal oxygen-isotope compilation (e.g,. Zachos et al., 2008) is sometimes interpreted as a global climate curve (e.g., Hansen et al., 2010), but actually, it mainly is a record of high-latitude climate. Even though the benthic foraminifera span the latitudes, the deep ocean water in which they calcified was mostly derived from high-latitude source regions where the surface water was dense enough to sink. The growth and decay of continental ice sheets also occurs mainly at high latitudes. Hence, the benthic record ideally should be matched with sea surface temperature (SST) $\delta^{18} \mathrm{O}$ records from planktonic foraminifera from all latitudes, and especially the tropics, to determine a fuller picture of oceanic temperature variation through time.

First, however, it is necessary to determine 
the relative depth stratification of fossil planktonic species so that SSTs can be investigated. Most common species have been analyzed for $\delta^{18} \mathrm{O}$ (and $\delta^{13} \mathrm{C}$, which gives additional information), allowing relative depth rankings to be established as far back as the mid-Cretaceous (notably Douglas and Savin, 1978; Boersma et al., 1979, 1987; Savin et al., 1985; Shackleton et al., 1985; Corfield and Cartlidge, 1991; Pearson et al., 1993; Pearson and Shackleton 1995; D'Hondt and Arthur, 1995; Huber et al., 1995; Lu and Keller, 1996; Norris and Wilson, 1998; Wilson and Norris, 1998; Abramovich et al., 2002; Wilson et al., 2002; Sexton et al., 2006; Pearson and Wade, 2008). Taking advantage of the excellent fossil record of foraminifera, stable-isotope evidence of depth habitats has been used frequently in evolutionary paleobiology, for example, to study speciation (Norris et al. 1996; Pearson et al., 1997), habitat evolution (Norris et al., 1993; Hodell and Vayavananda, 1993; Schneider and Kennett, 1996; Coxall et al., 2000, 2007; Ando et al., 2010), and macroevolution in relation to environmental change (Ezard et al. 2011).

The first long-term records of planktonic foraminifer $\delta^{18} \mathrm{O}$ were made during the first phase of deep-sea drilling (Douglas and Savin, 1971, 1973; Shackleton and Kennett, 1975). Comparisons between planktonic and benthic records suggested that the $\delta^{18} \mathrm{O}$ difference between them was relatively low in the early Cenozoic and had increased with time (Douglas and Savin, 1973; see Figure 14; see also Shackleton and Kennett, 1975, Savin et al., 1975, Boersma et al., 1979, Berger, 1979). In these studies, planktonic foraminiferal paleotemperature estimates for the Paleogene and Late Cretaceous were found to be in the range 20 $25^{\circ} \mathrm{C}$ for tropical sites, which is considerably cooler than modern tropical SSTs, which peak around $30^{\circ} \mathrm{C}$. Berger $(1979 \mathrm{~b})$ pointed out that the low global temperature gradients implied by these studies indicate that mean wind velocities, ocean currents, upwelling, and downwelling would all be very much slower at these times in the past. Shackleton and Boersma (1981) reviewed the then available data, finding (like Berger, 1979b) that high-latitude surface temperatures were warmer than modern (consistent with an absence of large ice sheets), but tropical temperatures were substantially cooler, with maximum values of about $23^{\circ} \mathrm{C}$. They suggested that more efficient transport of heat by ocean currents might have warmed the poles at the expense of the tropics, creating the ice-free Eocene climate.

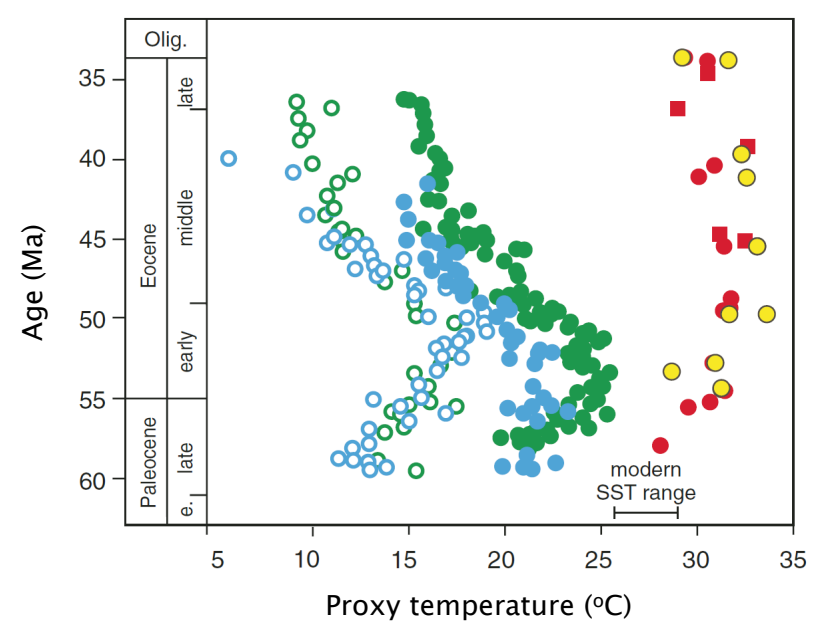

FIGURE 15.- The evolution of late Paleocene and Eocene paleotemperatures as reconstructed from foraminifera from deep ocean sites (ODP 1219; ODP 865) and the exceptionally well-preserved succession in Tanzania with 'TEX-86' paleotemperature estimates for Tanzania are also shown. Open symbols: benthic foraminifera (not available from Tanzania) and filled symbols: surface dwelling planktonic foraminifera. The difference in tropical SST is larger than can be explained by regional variation and was attributed to the recrystallized state of the open ocean sites, which makes planktonic foraminiferal records converge on the benthic foraminiferal records. (From Pearson et al., 2007)

A similar picture of low tropical temperatures and reduced latitudinal temperature gradients also began to emerge from Miocene compilations (Savin et al., 1985; Keller, 1985) and the Cretaceous (Douglas and Savin, 1978; Shackleton, 1984; D'Hondt and Arthur, 1996) (see Grossman, 2010 , for a recent compilation of data). However, the pattern seemed at odds with paleontological data, which indicated warm tropical temperatures during these climate states (reviewed by Adams et al., 1990). When GCM simulations began to be applied to past climates, the low-gradient temperature pattern demanded by the Berger/ Shackleon/Boersma theory of Eocene climate proved impossible to reproduce (Barron, 1987, Bush and Philander, 1997; Bice et al., 2000), which remains very much the case today. As Barron (1987, p. 729) put it: "The lack of consistency between model results, oceanic data, and terrestrial data defines the nature of the problem of Eocene climates. The solution must involve reinterpretation of at least one major source of information." D'Hondt and Arthur (1996) called it the 
'cool tropic paradox' in relation to the Cretaceous. In their review of the problem, Crowley and Zachos (2000) pointed out that the lack of evidence for warmer than modern tropical SSTs in the past, if substantiated, would provide an important constraint on climate models.

The possibility that diagenetic alteration of foraminiferal calcite biases measured paleotemperatures towards cold estimates has long been suspected (Killingley, 1983) but was not generally thought to be a major effect, partly because interspecies isotopic differentials are consistently observed in the deep-sea record (Crowley and Zachos, 2000). However, some evidence for warm tropical SSTs did begin to emerge (e.g., Wilson and Opdyke, 1996, based on coral aragonite and early diagenetic cements; also Norris and Wilson, 1998; Wilson and Norris, 2001, from exceptionally well-preserved planktonic foraminifera from the mid-Cretaceous claystones). Pearson et al. (2001) analyzed exceptionally well-preserved Late Cretaceous and Eocene foraminiferal assemblages from clay-rich sediments from Tanzania and elsewhere (Figures 1, 10), and argued that seafloor diagenetic micron-scale recrystallization in carbonate oozes had the effect of partially homogenizing the $\delta^{18} \mathrm{O}$ and $\delta^{13} \mathrm{C}$ differences, causing substantial ${ }^{18} \mathrm{O}$ enrichment but not destroying interspecies differences altogether (Figure 11).

Pearson et al. (2007) reported data from more exceptionally well-preserved foraminiferal assemblages from a series of drill cores and outcrop samples from the hemipelagic clays of Tanzania (Figure 15), and compared the data with tropical Eocene $\delta^{18} \mathrm{O}$ records from the Pacific (Bralower et al., 1995; Dutton et al., 2005). Whereas the deep-sea records suggest that temperatures peaked around $25^{\circ} \mathrm{C}$ in the early Eocene and declined thereafter to about $17^{\circ} \mathrm{C}$ in the late Eocene (similar to Douglas and Savin, 1973, see Figure 14; and many subsequent studies), the Tanzania temperatures are mostly $>30^{\circ} \mathrm{C}$ (i.e., warmer than modern) and do not show a marked decline. The warm temperature reconstructions were supported by the TEX-86 organic paleothermometer (also shown in Figure 15). Wilson and Norris (2002) compared glassy and recrystallized foraminifera from the mid-Cretaceous and found that the glassy specimens yielded much warmer paleotemperature estimates. The implication of these studies is that diagenetic micro-recrystallization can reduce apparent planktonic foraminiferal temperatures by $>10^{\circ} \mathrm{C}$ in the tropics, where the temperature of calcification in the surface ocean is most different from that of early diagenesis on the sea floor. The effect would be much reduced at high latitudes, hence diagenesis can contribute to an apparent flattening of the meridional temperature gradient as well as a reduction of tropical temperatures (Schrag, 1999; Pearson et al., 2001). Other evidence for warm $\delta^{18} \mathrm{O}$ temperatures from well-preserved foraminifera supported, in some cases, by a range of other proxies has been provided by Huber et al. (2002), Bice et al. (2003, 2006), Stewart et al. (2004), Zachos et al. (2006), Burgess et al. (2008), Bornemann et al. (2008), Pearson and Wade (2009), and Wade et al. (2012). Unlike much of the data from recrystallized foraminifera, such results are generally in line with GCM simulations with high $\mathrm{CO}_{2}$ forcing (Huber, 2008; Tindall et al., 2010; Roberts et al., 2011; Huber and Caballero, 2011). The prevailing view is that the Cretaceous and Paleogene warm climate states were extreme greenhouse climates (Huber, 2008), and are comparable to simulations of future climate with anthropogenic greenhouse warming.

\section{The multiproxy revolution}

In paleoceanographic studies, we would frequently like to know some parameter from the past that cannot be measured directly (e.g., temperature, $\mathrm{pH}, \mathrm{pCO}_{2}, \mathrm{pO}_{2}$, circulation patterns, nutrients, levels of biological productivity) so we must find something that can be measured that would have responded to the target variable. These are paleoclimate proxies, and oxygen isotopes of biogenic carbonates are a classic example. They have been joined gradually by a wide range of other isotopic and geochemical proxies, some of which are measured on foraminifera and others on bulk sediment or organic compounds in the cores. It is increasingly common to find two or more proxies used together in an attempt to reduce the degrees of freedom in determining paleoenvironmental conditions. A common example is the combined use of $\mathrm{Mg} / \mathrm{Ca}$ ratios and $\delta^{18} \mathrm{O}$ : the former as an indicator of temperature and the latter, taking that value into account, of $\delta^{18} \mathrm{O}_{\text {sw. }}$.

Multiproxy studies involving $\delta^{18} \mathrm{O}$ have tackled many of the foremost problems in paleoceanographic research from the temperature and salinity of the glacial ocean (Kucera et al., 2007) to the temperature and $\mathrm{CO}_{2}$ content of the early and mid-Cretaceous (McArthur et al., 2007; Bice et al., 2006). Every proxy has its limitations, so the use of multiple proxies is essential if important variables, such as sea-surface temperatures, sea- 
level variations, and ice fluctuations are to be determined, especially for the distant past. Using proxies together can help highlight when one or another is compromised. An ideal study would use a range of inorganic and organic proxies in combination with model results. The literature is too vast to review here, but the approach can be exemplified by studies of the Eocene-Oligocene transition (EOT), the largest permanent shift in the global climate state of the Cenozoic (highlighted on Figure 13). This transition corresponds to a large $\sim 1.5 \%$ shift in deep-sea benthic foraminiferal $\delta^{18} \mathrm{O}$. When initially discovered (Devereux, 1967; Shackleton and Kennett, 1975; Kennett and Shackleton, 1976; Savin, 1977), the entire isotope shift was attributed to deep-sea cooling. Interpretations of later records invoked a combination of cooling and ice growth (e.g. Keigwin, 1980; Keigwin and Corliss, 1986; Poore and Matthews, 1984; Shackleton, 1986; Miller et al., 1987). The discovery of ice-rafted debris and glaciomarine sediments of Oligocene age (Hambrey et al., 1991; Zachos et al., 1992) suggested that at least some component of ice growth was likely to be in the signal. Surprisingly, the first combined measurements of $\delta^{18} \mathrm{O}$ and $\mathrm{Mg} / \mathrm{Ca}$ ratios in foraminifera failed to detect any deep-sea cooling, so the isotope shift was interpreted as a signal of ice growth alone, the exact opposite of the initial interpretation (Lear et al., 2000). This result was problematic, however, because it would seem to demand growth of an Oligocene ice sheet larger than the modern one (Coxall et al., 2005). The discovery that $\mathrm{Mg} / \mathrm{Ca}$ ratios are affected by $\left[\mathrm{CO}_{3}{ }^{2-}\right]$ (Elderfield et al., 2006) led to a reappraisal of the records (Lear and Rosenthal, 2006). Subsequent combined proxy studies have tended to suggest a roughly equal component of both ice growth and cooling (Lear et al., 2008; Katz et al., 2008; Peck et al., 2010; Pusz et al., 2011; Bohaty et al., 2012; Wade et al., 2012), although very precise estimates are difficult to achieve because of the combined analytical uncertainties and reproducibility (Billups and Schrag, 2002). It is possible to accommodate all of this early Oligocene ice on Antarctica, especially if Antarctic ice was considerably less depleted in ${ }^{18} \mathrm{O}$ than it is now (Deconto et al., 2008) or if there was a larger continental area above sea level than has generally been assumed (Wilson et al., 2012).

Oxygen-isotope analysis of foraminifera continues to be one of the most important tools in paleoclimate research. In recent years, two other significant developments have occurred that are providing fresh directions for the application of oxygen isotopes: first, the ability to analyze small sample spots by laser ablation ICP-MS (e.g. Reichart et al., 2003) or ion microprobe (Kozdon et al., 2009, 2011); and second, the measurement of the $\mathrm{CO}_{2}$ isotopologues that can, in principle, provide simultaneous information about both temperature and $\delta^{18} \mathrm{O}_{\mathrm{sw}}$ without the need for assuming one or the other (Eiler, 2007). These developments are already affecting the interpretation of the more traditional whole-specimen analyses, but are reviewed by other papers in this volume so will not be discussed further here.

\section{CONCLUSIONS}

Harold Urey (1893-1981) was awarded the Arthur L. Day Medal of the Geological Society of America and the Goldschmidt Medal of the Geochemical Society for his geologic thermometer to sit alongside his 1934 Nobel Prize for the discovery of deuterium. The main caveats identified by Urey (1948) — variations in $\delta^{18} \mathrm{O}_{\mathrm{sw}}$, vital-effect fractionations, and diagenesis - have all been the subject of intense debate. Application to foraminifera and deep-sea sediments might have developed slowly had it not been for the industry and insights of Cesare Emiliani, who accelerated the field rapidly in the 1950s, and identified the main research themes of paleoceanography. The oxygen-isotope method has turned out to be just as important for determining fluctuations in past global ice volume as it has past temperatures. Data from foraminifera have provided us with invaluable records of global change on astronomical timescales, proving the orbital theory of the ice ages, and, over multimillion-year timescales, revealing, in detail, how global climate has evolved from a greenhouse to an icehouse state.

\section{ACKNOWLEDGMENTS}

Ben Cramer and Dick Norris provided detailed and insightful reviews. The manuscript has also benefited from the comments of Helen Coxall, Ethan Grossman, Brian Huber, Howie Spero, and Bridget Wade.

\section{REFERENCES}

ABRAMOVICH, S., G. KELLER, D. STUBEN, AND Z. BERNER. 2003. Characterization of late Campanian and Maastrichtian planktonic foraminiferal depth habitats and vital activities based on stable 
isotopes. Palaeogeography, Palaeoclimatology, Palaeoecology, 202:1-29.

ADAMS, C. G., D. E. LEE, AND B. R. ROSEN. 1990. Conflicting isotopic and biotic evidence for tropical sea-surface temperatures during the Tertiary. Palaeogeography, Palaeoclimatology, Palaeoecology, 77:289-313.

ALLEGRE, C. 2008. Isotope Geology. Cambridge University Press, Cambridge, $512 \mathrm{p}$.

ANDO, A., B.T. HUBER, AND K.G. MACLEOD. 2010. Depth-habitat reorganization of planktonic foraminifera across the Albian/Cenomanian boundary. Paleobiology, 36:357-373.

AURAHS, R., M. GÖKER, G. W. GRIMM, V. HEMLEBEN, C. HEMLEBEN, R. SCHIEBEL, AND M. KUČERA. 2009. Using the multiple analysis approach to reconstruct relationships among planktonic foraminifera from highly divergent and length-polymorphic SSU rDNA sequences. Bioinformatics and Biology Insights, 3:155-157.

AZE, T., T. H. G. EZARD, A. PURVIS, H. K. COXALL, D. R. M. STEWART, B. S. WADE, AND P. N. PEARSON. 2011. A phylogeny of Cenozoic macroperforate planktonic foraminifera from fossil data. Biological Reviews, 86:900-927.

BAR-MATTHEWS, M., A. AYALON, M. GILMOUR, A. MATTHEWS, AND C. J. HAWKESWORTH. 2003. Sea-land oxygen isotopic relationships from planktonic foraminifera and speleothems in the Eastern Mediterranean region and their implication for paleorainfall during interglacial intervals. Geochimica et Cosmochimica Acta, 67, 31813199.

BARRAS, C., J.-C. DUPLESSY, E. GESLIN, E. MICHEL, AND F. J. JORISSEN. 2010. Calibration of $\delta^{18} \mathrm{O}$ of cultured benthic foraminiferal calcite as a function of temperature. Biogeosciences, 7:13491356.

BARRON, E. J. 1987. Eocene equator-to-pole surface ocean temperatures: a significant climate problem? Paleoceanography, 2:729-739.

BASSINOT, F. C., L. D. LABEYRIE, E. VINCENT, X. QUIDELLEUR, N. J. SHACKLETON, AND Y. LANCELOT. 1994. The astronomical theory of climate change and the age of the BrunhesMatuyama magnetic reversal. Earth and Planetary Science Letters, 126:91-108.

BÉ, A. W. H. 1980. Gametogenic calcification in a spinose planktonic foraminifer, Globigerinoides sacculifer (Brady). Marine Micropaleontology, 5:283-310.

BÉ, A. W. H., J. W. MORSE, AND S. M. HARRISON. 1975. Progressive dissolution and ultrastructural breakdown of planktonic foraminifera, p. 27-55. In W. V. Sliter, A. W. H. BÉ, AND W. H. Berger (eds.). Dissolution of Deep Sea Carbonates. Cushman Foundation for Foraminiferal Research, Special Publication, No. 13.
BECK, W. C., E. L. GROSSMAN, AND J. W. MORSE. 2005. Experimental studies of oxygen isotope fractionation in the carbonic acid system at $15^{\circ}$, $25^{\circ}$, and $40^{\circ} \mathrm{C}$. Geochimica et Cosmochimica Acta, 69:3493-3503.

BEMIS, B. E., H. J. SPERO, J. BIJMA, AND D. W. LEA. 1998. Reevaluation of the oxygen isotopic composition of planktonic foraminifera: Experimental results and revised palaeotemperature equations. Paleoceanography, 13:150-160.

BENTOV, S., C. BROWNLEE, AND J. EREZ. 2009. The role of seawater endocytosis in the biomineralization process in calcareous foraminifera. Proceedings of the National Academy of Sciences, 106:21500-21504.

BERGER, W. H. 1971. Sedimentation of planktonic foraminifera. Marine Geology, 11:325-358.

BERGER, W. H. 1979a. Preservation of foraminifera, p. 105-155. In J. LIPPS, W. H. BERGER, M. A. BUZAS, R. G. Douglas, AND C. A. Ross (eds.). Foraminiferal Ecology and Paleoecology, SEPM Short Course No. 6. Society of Economic Paleontologists and Mineralogists, Houston, TX.

BERGER, W. H. 1979b. Stable isotopes in foraminifera, p. 156-198. In J. LIPPS, W. H. BERGER, M. A. Buzas, R. G. Douglas, AND C. A. Ross (eds.). Foraminiferal Ecology and Paleoecology, SEPM Short Course No. 6. Society of Economic Paleontologists and Mineralogists, Houston, TX.

BICE, K. L., D. BIRGEL, P. A. MEYERS, K. A. DAHL, K.-U. HINRICHS, AND R. D. NORRIS. 2006. A multiple proxy and model study of Cretaceous upper ocean temperatures and atmospheric $\mathrm{CO}_{2}$ concentrations. Paleoceanography, 21: doi:10.1029/2005PA001203.

BICE, K. L., B. T. HUBER, AND R. D. NORRIS. 2003. Extreme polar warmth during the Cretaceous greenhouse? Paradox of the late Turonian $\delta^{18} \mathrm{O}$ record at Deep Sea Drilling Project Site 511. Paleoceanography, 18, doi:10.1029/2002PA000848.

BICE, K. L., C. R. SCOTESE, D. SEIDOV, AND E. J. BARRON. 2000. Quantifying the role of geographic change in Cenozoic ocean transport using uncoupled atmosphere and ocean models. Palaeogeography, Palaeoclimatology, Palaeoecology, 161:295-310.

BIGG, G. R., AND E. J. ROHLING. 2000. An oxygen isotope dataset for marine waters. Journal of Foraminiferal Research, 105:8527-8536.

BIJMA, J., H. J. SPERO, AND D. W. LEA. 1999. Reassessing foraminiferal stable isotope geochemistry: Impact of the oceanic carbonate system (experimental results), p. 489-512. In G. FISCHER (ed.). Use of Proxies in Paleoceanography: Examples for the South Atlantic. Springer Verlag, Berlin.

BILLUPS, K., AND D. P. SCHRAG. 2002. Paleotempertures and ice volume of the past $27 \mathrm{Myr}$ revisited with paired $\mathrm{Mg} / \mathrm{Ca}$ and ${ }^{18} \mathrm{O} /{ }^{16} \mathrm{O}$ measurements on 
benthic foraminifera. Paleoceanography, 17:doi:10.1029/2000PA000567

BIRCH, H., H. K. COXALL, P. N. PEARSON, AND D. KROON. Submitted. Planktonic foraminiferal stable isotopes: ecological niches and disequilibrium fractionation effects. Marine Micropaleontology.

BISSETT, A., T. R. NEU, AND D. DE BEER. 2011. Dissolution of calcite in the twilight zone: bacterial control of dissolution of sinking planktonic carbonates is unlikely. PLoS ONE 6(11):e26404. doi:10.1371/journal.pone.0026404.

BOERSMA, A., I. PREMOLI SILVA AND N. J. SHACKLETON. 1987. Atlantic Eocene planktonic foraminiferal paleohydrographic indicators and stable isotope paleoceanography. Paleoceanography, 2:287-331.

BOERSMA, A., N. J. SHACKLETON, M. A. HALL, AND Q. GIVEN. 1979. Carbon and oxygen isotope records at DSDP Site 384 (North Atlantic) and some Paleocene paleotemperatures and carbon isotope variations in the Atlantic Ocean. Initial Reports of the Deep Sea Drilling Project, 43:695715.

BOHATY, S. M., J. C. ZACHOS, AND M. L. DELANEY. 2012. Foraminiferal $\mathrm{Mg} / \mathrm{Ca}$ evidence for Southern Ocean cooling during the Eocene-Oligocene transition. Earth and Planetary Science Letters, 317-318:251-261.

BORNEMANN, A., R. D. NORRIS, O. FRIEDRICH, B. BECKMANN, S. SCHOUTEN, J. S. SINNNINGE DAMSTÉ, J. VOGEL, P. HOFMANN, AND T. WAGNER. 2008. Isotopic evidence for glaciation during the Cretaceous supergreenhouse. Science, 319:189-192.

BOUVIER-SOUMAGNAC, Y., AND J.-C. DUPLESSY. 1985. Carbon and oxygen isotopic composition of planktonic foraminifera from laboratory culture, plankton tows and recent sediment; implications for the reconstruction of paleoclimatic conditions and of the global carbon cycle. Journal of Foraminiferal Research, 15: 302-320.

BRALOWER, T. J., J. C. ZACHOS, E. THOMAS, M. PARROW, C. K. PAULL, D. C. KELLY, I. PREMOLI SILVA, W. V. SLITER, AND K. C. LOHMANN. 1995. Late Paleocene to Eocene paleoceanography of the equatorial Pacific Ocean: Stable isotopes recorded at Ocean Drilling Program Site 865, Allison Guyot. Paleoceanography, 10:841-865.

BROECKER, W. S. 1989. The salinity contrast between the Atlantic and Pacific oceans during glacial time. Paleoceanography, 4:207-212.

BROECKER, W. S. 1998. Paleocean circulation during the last deglaciation: a bipolar seesaw? Paleoceanography, 13:doi:10.1029/97PA03707.

BROECKER, W. S., AND T.- H. PENG. 1982. Tracers in the Sea. Eldigio Press, Lamont Doherty Geo- logical Observatory, $690 \mathrm{pp}$.

BURGESS, C. E., P. N. PEARSON, C. H. LEAR, H. E. G. MORGANS, L. HANDLEY, R. D. PANCOST, AND S. SCHOUTEN. 2008. Middle Eocene climate cyclicity in the southern Pacific: Implications for global ice volume. Geology, 36:651-654.

BUSH, A. B. G., AND S. G. H. PHILANDER. 1997. The late Cretaceous: simulation with a coupled atmosphere-ocean general circulation model. Paleoceanography, 12:495-516.

CLARK, P. U., N. G. PISIAS, T. F. STOCKER, AND A. J. WEAVER. 2002. The role of the thermohaline circulation in abrupt climate change. Nature, 415:863-869.

CLEMENT, A. C., AND L. C. PETERSON. 2006. Mechanisms of abrupt climate change of the last glacial period. Reviews of Geophysics, 46: RG4002, doi:10.1029/2006RG000204.

CLIMAP PROJECT MEMBERS. 1976. The surface of the ice age earth. Science, 191:1131-1137.

COPLEN, T. B. 1994. Reporting of stable hydrogen, carbon, and oxygen abundances. Pure and Applied Chemistry, 2:273-276.

CORFIELD, R. M., AND J. E. CARTLIDGE. 1991. Isotopic evidence for the depth stratification of fossil and recent Globigerinina: a review. Historical Biology, 5:37-63.

CORFIELD, R. M., M. A. HALL, AND M. D. BRASIER. 1990. Stable isotope evidence for foraminiferal habitats during the Cenomanian / Turonian anoxic event. Geology, 18:175-178.

COSTA, K. B., F. A. L. TOLEDO, M. A. G. PIVEL, C. A. V. MOURA, AND F. CHEMALE. 2006. Evaluation of two genera of benthic foraminifera for down-core paleotempertaure studies in the western South Atlantic. Brazilian Journal of Oceanography, 54:75-84.

COXALL, H. K., P. N. PEARSON, N. J. SHACKLETON, AND M. A. HALL. 2000. Hantkeninid depth adaptation: an evolving life strategy in a changing ocean. Geology, 28:87-90.

COXALL, H., P. A. WILSON, H. PÄLIKE, C. H. LEAR, AND J. BACKMAN. 2005. Rapid stepwise onset of Antarctic glaciation and deeper calcite compensation in the Pacific Ocean. Nature, 433:53-57.

COXALL, H. K., P. A. WILSON, P. N. PEARSON, AND P. F. SEXTON. 2007. Iterative evolution of digitate planktonic foraminifera. Paleobiology, 33:495-516.

CRAIG, H. 1953. The geochemistry of stable isotopes of carbon. Geochimica et Cosmochimica Acta, 3:53-72.

CRAIG, H. 1965. Measurement of oxygen isotope paleotemperatures, p. 162-182. In E. TONGIORGI (ed.). Stable Isotopes in Oceanographic Studies and Paleotemperatures. Cons. Naz. Delle Ric., Spoleto, Italy. 
CRAMER, B. S., K. G. MILLER, P. J. BARRETT, AND J. D. WRIGHT. 2011. Late Cretaceous-Neogene trends in deep ocean temperature and continental ice volume: Reconciling records of benthic foraminiferal geochemistry $\left(\delta^{18} \mathrm{O}\right.$ and $\left.\mathrm{Mg} / \mathrm{Ca}\right)$ with sea level history. Journal of Geophysical Research, 116:C12023, doi:10.1029/2011JC007255.

CRAMER, B. S., J. R. TOGGWEILER, J. D. WRIGHT, M. W. KATZ, AND K. G. MILLER. 2009. Ocean overturning since the Late Cretaceous: Inferences from a new benthic foraminiferal isotope compilation. Paleoceanography, 24 :PA4216, doi:10.1029/2008PA001683.

CROLL, J. 1875. Climate and Time, in their Geological Relations: A Theory of Secular Changes of the Earth's Climate. Daldy, Tbister and Company, London, 577 p.

CRONIN, T. 1999. Principles of Paleoclimatology, Columbia University Press, New York, 560 p.

CROWLEY, T. J., AND W. T. HYDE. 2008. Transient nature of late Pleistocene climate variability. Nature, 456:226-230.

CROWLEY, T. J., AND J. C. ZACHOS. 2000. Comparison of zonal temperature profiles for past warm time periods, p. 50-76. In B. T. HUBER, K. G. MACLEOD, AND S. L. WING (eds.). Warm Climates in Earth History, Cambridge University Press, Cambridge UK.

CURRY, W. B., AND T. J. CROWLEY. 1987. The $\delta^{13} \mathrm{C}$ of equatorial Atlantic surface waters: Implications for Ice Age $\mathrm{pCO}_{2}$ levels. Paleoceanography, 2:489-517.

CURRY, W. B., R. C. THUNELL, AND S. HONJO. 1983. Seasonal changes in the isotopic composition of planktonic foraminifera collected in Panama Basin sediment traps. Earth and Planetary Science Letters, 64:33-43.

CUTLER, K. B., R. L. EDWARDS, F. W. TAYLOR, H. CHENG, J. ADKINS, C. D. GALLUP, P. M. CUTLER, G. S. BURR, AND A. L. BLOOM. 2003. Rapid sea-level fall and deep ocean temperature change since the last interglacial period. Earth and Planetary Science Letters, 206:253-271.

DANSGAARD, W., S. J. JOHNSON, AND J. MILLER. 1969. One thousand centuries of climatic record from Camp Century on the Greenland ice sheet. Science, 166:377-380.

DANSGAARD, W., AND H. TAUBER. 1969. Glacier oxygen-18 content and Pleistocene ocean temperatures. Science, 166:499-502.

DARLING, K. F., AND C. M. WADE. 2008. The genetic diversity of planktonic foraminifera and the global distribution of ribosomal genotypes. Marine Micropaleontology, 67:216-238.

DE VARGAS, C., R. NORRIS, L. ZANINETTI, S. W. GIBB, AND J. PAWLOWSKI. 1999. Molecular evidence of cryptic speciation in planktonic foraminifers and their relation to oceanic provinces.
Proceedings of the National Academy of Sciences, 96:2864-2868.

DECONTO, R. M., D. POLLARD, P. A. WILSON, H. PALIKE, C. H. LEAR, AND M. PAGANI. 2008. Thresholds for Cenozoic bipolar glaciation. Nature, 455:652-656.

DEUSER, W. G., AND E. H. ROSS. 1989. Seasonally abundant planktonic foraminifera of the Sargasso Sea: Succession, deep-water fluxes, isotopic compositions, and paleoceanographic implications. Journal of Foraminiferal Research, 19:268-293.

DEVEREUX, L. 1967. Oxygen isotope paleotemperature measurements on New Zealand Tertiary fossils. New Zealand Journal of Science, 10:9881011.

D'HONDT, S., AND M. A. ARTHUR. 1995. Interspecies variation in stable isotopic signals of Maastrichtian planktonic foraminifera. Paleoceanography, 10:123-135.

D'HONDT, S., AND M. A. ARTHUR. 1996. Late Cretaceous oceans and the cool tropic paradox. Science, 271:1838-1841.

DOKKEN, T. M., AND E. JANSSEN. 1999. Rapid change in the mechanism of ocean convection during the glacial period. Nature, 401:458-461.

DOUGLAS, R. G., AND S. M. SAVIN. 1971. Isotopic ananlyses of planktonic forminifera from the Cenozoic of the northwest Pacific, Leg 6. Initial Reports of the Deep Sea Drilling Project, 6:11231127.

DOUGLAS, R. G., AND S. M. SAVIN. 1973. Oxygen and carbon isotope analysis of Cretaceous and Tertiary foraminifera from the central north $\mathrm{Pa}$ cific. Initial Reports of the Deep Sea Drilling Project, 17:591-605.

DOUGLAS, R. G., AND S. M. SAVIN. 1978. Oxygen isotopic evidence for the depth stratification of the Tertiary and Cretaceous planktonic foraminifera. Marine Micropaleontology, 3:175-196.

DUNBAR, R. B., AND G. WEFER. 1984. Stable isotope fractionation in benthic foraminifera from the Peruvian continental margin. Marine Geology, 59:215-225.

DUPLESSY, J. C., P. BLANC, AND A. W. H. BÉ. 1981. Oxygen-18 enrichment of planktonic forminifera due to gametogenic calcification below the euphotic zone. Science, 213:1247-1250.

DUPLESSY, J. C., C. LALOU, AND A. C. VINOT. 1970. Differential isotopic fractionations in benthic foraminifera and paleotemperatures reassessed. Science, 138:250-251.

DUTTON, A., K. C. LOHMANN, AND R. M. LECKIE. 2005. Insights from the Paleogene tropical Pacific: Foraminiferal stable isotope and trace elemental results from Site 1209, Shatsky Rise. Paleoceanography, 20, doi:10.1029/2004PA001098.

ELDERFIELD, H., J. YU, P. ANAND, T. KIEFER, AND B. NYLAND. 2006. Calibrations for benthic 
foraminiferal $\mathrm{Mg} / \mathrm{Ca}$ paleothermometry and the carbonate ion hypothesis. Earth and Planetary Science Letters, 250:633-649.

EMILIANI, C. 1954a. Depth habitats of some pelagic foraminifera as indicated by oxygen isotope ratios. American Journal of Science, 252:149-158.

EMILIANI, C. 1954b. Temperature of Pacific bottom waters and polar superficial waters during the Tertiary. Science, 119:853-855.

EMILIANI, C. 1955. Pleistocene temperatures. Journal of Geology, 63:538-578.

EMILIANI, C. 1958. Ancient temperatures. Scientific American, 198: 54-66.

EMILIANI, C. 1961. The temperature decrease of surface water in high latitudes and of abyssal-hadal water in open oceanic basins during the past 75 million years. Deep Sea Research, 8:144-147.

EMILIANI, C. 1966. Isotopic paleotemperatures. Science, 154:851-857.

EMILIANI, C. 1978. The cause of the ice ages. Earth and Planetary Science Letters, 37:349-352.

EMILIANI, C. 1991. Planktic/planktonic, nektic/ nektonic, benthic/benthonic. Journal of Paleontology, 65:329.

EMILIANI, C. 1992. Pleistocene paleotemperatures. Science, 257:1462.

EPSTEIN, S. R. 1997. The role of stable isotopes in geochemistries of all kinds. Anuual Review of Earth and Planetary Sciences, 25:1-21.

EPSTEIN, S., R. BUCHSBAUM, H. A. LOWENSTAM, AND H. C. UREY. 1953. Revised carbonate-water isotopic temperature scale. Geological Society of America Bulletin, 64:13151325.

EREZ, J. 1978. Vital effect on stable-isotope composition seen in foraminifera and coral skeletons. Nature, 273:199-202.

EREZ, J. 2003. The source of ions for biomineraliation in foraminifera and their implications for paleoceanographic proxies. Reviews in Mineralogy and Geochemistry, 54:115-149.

EREZ, J., AND B. LUZ. 1983. Experimental paleotemperature equation for planktonic foraminifera. Geochimica et Cosmochimica Acta, 47:10251031.

ERICSON, D. B., W. S. BROECKER, J. L. KULP, AND G. WOLLIN. 1956. Late Pleistocene climates and deep-sea sediments. Science, 124:385-389.

ERICSON, D. B., AND G. WOLLIN. 1956. Micropaleontological and isotopic determinations of Pleistocene climates. Micropaleontology, 2:257-270.

EZARD, T. H. G., T. AZE, P. N. PEARSON, AND A. PURVIS. 2011. Interplay between changing climate and species' ecology drives macroevolutionary dynamics. Science, 332:349-351.

FAIRBANKS, R. G., M. SVERDLOVE, R. FREE, P. H. WIEBE, AND A. W. H. BÉ. 1982. Vertical distribution and isotopic fractionation of living planktonic foraminifera from the Panama Basin. Nature, 298:841-844.

FAUL, K. L., A. C. RAVELO, AND M. L. DELANEY. 2000. Reconstructions of upwelling, productivity, and photic zone depth in the eastern equatorial Pacific Ocean using planktonic foraminiferal stable isotopes and abundances. Journal of Foraminiferal Research. 30:110-125.

FAURE, G., AND T. M. MENSING. 2005. Isotopes: Principles and Applications, Third Edition. John Wiley and Sons, Hoboken, New Jersey, 897 p.

FILLIPSON, H. L., J. M. BERNHARD, S. A. LINCOLN, AND D. C. MCCORCKLE. 2010. A culture-based calibration of benthic foraminiferal paleotemperature proxies: $\delta^{18} \mathrm{O}$ and $\mathrm{Mg} / \mathrm{Ca}$ results. Biogeosciences, 7:1335-1347.

FRIEDRICH, O., R. D. NORRIS, AND J. ERBACHER. 2012b. Evolution of middle to Late Cretaceous oceans - a 55 m.y. record of Earth's temperature and carbon cycle. Geology, 40:107-110.

FRIEDRICH, O., R. SCHIEBEL, P. A. WILSON, S. WELDEAB, C. J. BEER, M. J. COOPER, AND J. FIEBIG. 2012a. Influence of test size, water depth, and ecology on $\mathrm{Mg} / \mathrm{Ca}, \mathrm{Sr} / \mathrm{Ca}, \delta^{18} \mathrm{O}$ and $\delta^{13} \mathrm{C}$ in nine modern species of planktic foraminifera. Earth and Planetary Science Letters, 319320:133-145.

FRIEDMAN, I., AND J. R. O’NEIL. 1977. Compilation of stable isotope fractionation factors of geochemical interest, p. 1-12. In M. FLEISCHER (ed.). Data of Geochemistry, U. S. Government Printing Office, Washington, DC.

GANSSEN, G. M., F. J. C. PEETERS, B. METCALFE, P. ANAND, S. J. A. JUNG, D. KROON, AND G.-J. BRUMMER, 2011. Quantifying sea surface temperature ranges of the Arabian Sea for the past 2000 years. Climate of the Past, 7:1337-1349.

GASPERI, J. T., AND J. P. KENNETT. 1993. Vertical thermal structure of Miocene surface waters: western equatorial paciic DSDP Site 289. Marine Micropaleontology, 22:235-254.

GRAHAM, D. W. B., B. H. CORLISS, M. L. BENDER, AND L. D. KEIGWIN. 1981. Carbon and oxygen isotopic disequilibria of Recent benthic foraminifera. Marine Micropaleontology, 6:483-497.

GROSSMAN, E. 1987. Stable isotopes in modern benthic foraminifera: a study of vital effect. Journal of Foraminiferal Research, 17:48-61.

GROSSMAN, E. 2010. Oxygen isotope stratigraphy. In F. M. GRAdSTEIN, J. G. OGG, AND A. SMITH (eds.). A New Geologic Time Scale. Cambridge Univeristy Press.

HAMBREY, M. J., W. U. EHRMANN, AND B. LARSEN. 1991. Cenozoic glacial record of the Prydz Bay continental shelf, East Antarctica. Proceedings of the Ocean Drilling Program, Scientific Results, 119:77-132. 
HANSEN, J., M. SATO, P. KHARECHA, D. BEERLING, R. BERNER, V. MASSON-DELMOTTE, M. PAGANI, M. RAYMO, D. L. ROYER, AND J. C. ZACHOS. 2010 Target atmospheric $\mathrm{CO}_{2}$ : Where should humanity aim? Open Atmospheric Science Journal, 2:217-231.

HAY, W. W., AND E. ZAKEVICH. 1999. Cesare Emiliani (1922-1995): the founder of paleoceanography. International Microbiology, 2:52-54.

HAYS, J. D., J. IMBRIE, AND N. J. SHACKLETON. 1976. Variations in earth's orbit: Pacemaker of the ice ages. Science, 194:1121-1132.

HEMLEBEN, C., M. SPINDLER, AND O.R. ANDERSON. 1989. Modern Planktonic Foraminifera. Springer-Verlag, New York, 363 p.

HERBERT, T. D., L. C. PETERSON, K. T., LAWRENCE, AND Z. LIU. 2010. Tropical ocean temperatures over the past 3.5 million years. Science, 328:1350-1354.

HODELL, D. A., AND A. VAYAVANANDA. 1993. Middle Miocene paleoceanography of the western equatorial Pacific and the evolution of Globorotalia (Fohsella). Marine Micropaleontology, 22:279-310.

HOEFS, J. 2009. Stable isotope geochemistry, $6^{\text {th }}$ Edition. Springer-Verlag, Berlin, $285 \mathrm{p}$.

HOLLIS, C. J., TAYLOR, K. W. R., L. HANDLEY, R. D. PANCOST, M. HUBER, J. B. CREECH, B. HINES, E. M. CROUCH, H. E. G. MORGANS, J. S. CRAMPTON, S. GIBBS, S. SCHOUTEN, P. N. PEARSON, AND J. C. ZACHOS. 2012. Southwest Pacific marine temperature history from late $\mathrm{Pa}-$ leocene to middle Eocene: Revisited. Earth and Planetary Science Letters.

HUBER, M. 2008. A hotter greenhouse? Science, 321:353-354.

HUBER, B. H., J. BIJMA, AND K. DARLING. 1997. Cryptic speciation in the living planktonic foraminifer Globigerinella siphonifera (d'Orbigny). Paleobiology, 23: 33-62.

HUBER, M., AND R. CABALLERO. 2011. The early Eocene equable climate problem revisited. Climate of the Past Discussions, 7:241-304.

HUBER, B. H., D. A. HODELL, AND C. P. HAMILTON. 1995. Middle-Late Cretaceous climate of the southern high latitudes: Stable isotopic evidence for minimal equator-to-pole thermal gradients. Geology, 107:1164-1191.

HUBER, B. T., R. D. NORRIS, AND K. G. MACLEOD. 2002. Deep-sea paleotemperature record of extreme warmth during the Cretaceous. Geology, 30:123-126.

HUBER, M., L. C. SLOAN, AND C. SHELLITO. 2003. Early Paleogene oceans and climate: fully coupled modeling approach using the NCAR CCSM, p. 25-47 In S. L. WING, P. D. Gingerich, B. Schmitz, AND E. THOMAS (eds.). Causes and consequences of globally warm climates in the early
Paleogene. Geological Society of America Special Paper, 369.

HUDSON, J. D., AND T. F. ANDERSON. 1989. Ocean temperatures and isotopic compositions through time. Transactions of the Royal Society of Edinburgh: Earth Sciences, 80:183-192.

HUT, G. 1987. Consultants group meeting on stable isotope reference samples for geochemical and hydrological investigations. International Atomic Energy Agency, Vienna, 42 p.

HUTCHINSON, G. E. 1974. De rebus planktonicis. Limnology and Oceanography, 19:360-361.

IMBRIE, J., A. BERGER, E. A. BOYLE, S. C. CLEMENS, A. DUFFY, W. R. HOWARD, G. KUKLA, J. KUTZBACH, D. G. MARTINSON, A. MCINTYRE, A. C. MIX, B. MOLFINO, J. J. MORLEY, L. C. PETERSON, N. G. PISIAS, W. L. PRELL, M. W. RAYMO, N. J. SHACKLETON, AND J. R. TOGGWEILER. 1993. On the structure and origin of major glaciation cycles 2. The 100,000-year cycle. Paleoceanography, 8:699-735.

IMBRIE, J., AND K. P. IMBRIE. 1979. Ice ages: solving the mystery. Harvard University Press, Cambridge Massachusetts, $224 \mathrm{p}$.

IVANOVA, E. 2000. Late Quaternary monsoon history and paleoproductivity of the western Arabian Sea. $\mathrm{PhD}$ thesis, Free University, Amsterdam, $172 \mathrm{p}$.

JAFFRÉS, J. B. D., G. A. SHIELDS, AND K. WALLMANN. 2007. The oxygen isotope evolution of seawater: A critical review of a long-standing controversy and an improved geological water cycle model for the past 3.4 billion years. Earth Science Reviews, 83:83-122.

J A H N E, R. A., D. B. CRAVEN, D. C. MCCORCKLE, AND C. E. REIMERS. 1997. Ca$\mathrm{CO}_{3}$ dissolution in California continental margin sediments: The influence of organic matter remineralisation. Geochimica et Cosmochimica Acta, 61:3587-3604.

KAHN, M. I. 1979. Non-equilibrium oxygen and carbon isotope fractionation in tests of living planktonic foraminifera. Oceanologia Acta, 2:195-208.

KAIHO, K., AND M. LAMOLDA. 1999. Catastrophic extinction of planktonic foraminifera at the Cretcaeous-Tertiary boundary evidenced by stable isotopes and foraminiferal abundance at Caravaca, Spain. Geology, 27:355-358.

KATZ, M., D. R. KATZ, J. D. WRIGHT, K. G. MILLER, D. K. PAK, N. J. SHACKLETON, AND E. THOMAS. 2003. Early Cenozoic benthic foraminiferal isotopes: species reliability and interspecies correction factors. Paleoceanography, 18: doi:10.1029/2002PA000798.

KATZ, M., K. G. MILlER, J. D. WRIGHT, B. S. WADE, J. V. BROWNING, B. S. CRAMER, AND Y. ROSENTHAL. 2008. Stepwise transition from the Eocene greenhouse to the Oligocene icehouse. Nature Geoscience, 1:329-333. 
KEIGWIN, L. D. 1980. Paleoceanographic changes in the Pacific across the Eocene-Oligocene boundary. Nature, 287:722-725.

KEIGWIN, L. D., AND B. H. CORLISS. 1986. Stable isotopes in late middle Eocene to Oligocene foraminifera. Geological Society of America, Bulletin, 97:335-345.

KELLER, G. 1985. Depth stratification of planktonic foraminifera in the Miocene ocean, p. 177-195. In J. P. KennetT (ed.). The Miocene Ocean: Paleoceanography and Biogeography. Geological Society of America, Memoir, No.163.

KELLY, D. C., T. J. BRALOWER, J. C. ZACHOS, I. PREMOLI SILVA, AND E. THOMAS. 1996. Rapid diversification of planktonic foraminifera in the tropical Pacific (ODP Site 865) during the late Paleocene thermal maximum. Geology, 24:423426.

KENNETT, J. P., AND SHACKLETON, N. J. 1976. Oxygen isotopic evidence for the development of the psychrosphere 38 Myr ago. Nature, 260:513515.

KILLINGLEY, J. S. 1983. Effects of diagnetic recrystallization on ${ }^{18} \mathrm{O} /{ }^{16} \mathrm{O}$ values in deep sea sediments. Nature, 201:594-597.

KILLINGLEY, J. S., R. F. JOHNSON, AND W. H. BERGER. 1981. Oxygen and carbon isotopes of individual shells of planktonic foraminifera from Ontong-Java Plateau, Equatorial Pacific. Palaeogeography, Palaeoecology, Palaeoclimatology, 33:193-204

KIM, S.-T., AND J. R. O'NEIL. 1997. Equilibrium and non-equilibrium oxygen isotope effects in synthetic carbonates. Geochimica et Cosmochimica Acta, 61:3461-3475.

KOUTAVAS, A., P. B. DE MENOCAL, G. C. OLIVE COL, AND J. LYNCH-STEIGLITZ. 2006. MidHolocene El Nino-Southern Oscillation (ENSO) attenuation revealed by individual foraminifera in eastern tropical Pacific sediments. Geology, 34:993-996.

KOZDON, R., D. C. KELLY, N. T. KITA, J. H. FOURNELLE, AND J. W. VALLEY. 2011. Planktonic foraminiferal oxygen isotope analysis by ion microprobe technique suggests warm tropical sea surface temperatures during the Early Paleogene. $\mathrm{P}$ a 1 e o c e a n o g r a p hy, 26 : P A 3206 , doi:10.1029/2010PA002056.

KUCERA, M., AND K. F. DARLING. 2002. Cryptic species of planktonic foraminifera: their effect on palaeoceanographic reconstructions. Philosophical Transactions of the Royal Society of London, A, 360:695-718.

KUCERA, M., A. ROSELL-MELÉ, R. SCHNEIDER, C. WAELBROECK, AND M. WEINELT. 2005. Multiproxy approach for the reconstruction of the glacial ocean (MARGO). Quaternary Science Reviews, 24:813-819.
LASKAR, J. 1999. The limits of Earth orbital calculations for geological time-scale use. Philosophical Transactions of the Royal Society, A, 357:17351759.

LASKAR, J., A. FIENGA, M. GASTINEAU, AND H. MANCHE. 2011. La2010: A new orbital solution for the long term motion of the Earth. Earth and Planetary Astrophysics: arXiv:1103.1084v1.

LEA, D. W. 2011. Elemental and isotopic proxies of past ocean temperatures, p. 227-253. In H. D. HOLlAND, AND K. K. TUREKIAN (eds.). Isotope geochemistry from the treatise on geochemistry. Elsevier, London.

LEAR, C. H., T. R. BAILEY, P. N. PEARSON, H. K. COXALL, AND Y. ROSENTHAL. 2008. Cooling and ice growth across the Eocene-Oligocene transition. Geology, 36:251-254.

LEAR, C. H., H. ELDERFIELD, AND P. A. WILSON. 2000. Cenozoic deep-sea temperatures and global ice volumes from $\mathrm{Mg} / \mathrm{Ca}$ in benthic foraminiferal calcite. Science, 287:269-272.

LEAR, C. H., AND Y. ROSENTHAL. 2006. Benthic foraminiferal $\mathrm{Li} / \mathrm{Ca}$ : insights into seawater carbonate saturation state. Geology, 34:985-988.

LEDUC, G., L. VIDAL, O. CARTAPANIS, AND E. BARD. 2009. Modes of eastern equatorial Pacific thermocline variability: Implications for ENSO dynamics over the last glacial period. Paleoceanography, 24, PA3202, doi:10.1029/2008PA001701.

LEE, J. L., J. PAWLOWSKI, J.- P. DEBENAY, J. WHITTAKER, F. BANNER, A. J. GOODAY, O. TENDAL., J. HAYNES, AND W. W. FABER. 2000. Phylum Granuloreticulosa. In J. L. LEE, G. F. LEEDAle, AND P. BRAdBURY (eds.). An Illustrated Guide to the Protozoa ( $2^{\text {nd }}$ edn.): Society of Protozoologists, Lawrence, Ks. 2 vols., 1432 p.

LEGRANDE, A. N., AND G. A. SCHMIDT. 2006. Global gridded data of the oxygen isotopic composition of seawater. Geophysical Research Letters, 33: doi:10.1029/2006gl026011.

L'HOMME, N., G. K. C. CLARKE, AND C. RITZ. 2005. Global budget of water isotopes inferred from polar ice sheets. Geophysical Research Letters, 32:L20502, doi:10.1029/2005GL023774.

LISIECKI, L. E., AND M. E. RAYMO. 2005. A Pliocene-Pleistocene stack of 57 globally distributed benthic $\delta^{18} \mathrm{O}$ records. Paleoceanography, 20:PA1003, doi:10.1029/2004PA001071.

LOHMANN, G. P. 1995. A model for variation in the chemistry of planktonic foraminifera due to secondary calcification and selective dissolution. $\mathrm{Pa}-$ leoceanography, 10:445-447.

LUTHI, D., M. LE FLOCH, B. BEREITER, T. BLUNIER, J.-M. BARNOLA, U. SIEGENTHALER, D. RAYNAUD, J. JOUZEL, H. FISCHER, K. KAWAMURA, AND T. F. STOCKER. 2008. High resolution carbon dioxide concentration record $650,000-800,000$ years before present. Nature, 
453:379-382.

LYNCH-STIEGLITZ, J., W. B. CURRY, AND N. SLOWEY. 1999. A geostrophic transport estimate for the Florida current from the oxygen isotopic composition of benthic foraminifera. Paleoceanography, 14:360-373.

MACKENSEN, A. 2001. Oxygen and carbon stable isotope tracers of Weddell Sea water masses: New data and some paleoceanographic implications. Deep-Sea Research Part 1, Oceanographic Research Papers, 48:1401-1422.

MCARTHUR, J. M., N. M. M. JANSSEN, S. REBOULET, M. J. LENG, M. F. THIRLWALL, AND B. VAN DE SCHOOTBRUGGE. 2007. Paleotemperatures, polar ice-volume, and isotope stratigraphy $\left(\mathrm{Mg} / \mathrm{Ca}, \delta^{18} \mathrm{O}, \delta^{13} \mathrm{C},{ }^{87} \mathrm{Sr} /{ }^{86} \mathrm{Sr}\right)$ : The Early Cretaceous (Berriasian, Valanginian, Hauterivian). Palaeogeography, Palaeoclimatology, Palaeoecology, 248:391-430.

MCCORKLE, D. C., J. M. BERNHARD, C. J. HINTZ, J. K. BLANKS, G. T. CHANDLER, AND T. J. SHAW. 2008. The carbon and oxygen stable isotopic composition of cultured benthic foraminifera, p. 135-154. In W. E. N. AUstin, AND R. J. JAMES (eds.). Biogeochemical Controls on Paleoceanographic Environmental Proxies, Geological Society of London, Special Publications, No. 303.

MCCREA, J. M. 1950. On the isotopic chemistry of carbonates and a paleotemperature scale. Journal of Chemical Physics, 18:849-857.

MCKINNEY, C. R., J. M. MCCREA, S. EPSTEIN, H. A. ALLEN, AND H. C. UREY. 1950. Improvements in mass spectrometers for the measurement of small differences in isotopic abundance ratio. Review of Scientific Instruments, 21:724-730.

MILANKOVITCH, M. 1941. Kanon der Erdbestrahlung und seine Anwendung auf das Eiszeitenproblem. Königlich Serbische Akademie, Belgrade, $132 \mathrm{p}$.

MILLER, K. G., R. G. FAIRBANKS, AND G. S. MOUNTAIN. 1987. Tertiary oxygen isotope synthesis, sea level history, and continental margin erosion. Paleoceanography, 2:1-19.

MILliMAN, J. D., P. J. TROY, W. M. BALCH, A. K. ADAMS, Y.-H. LI, AND F. T. MACKENZIE. 1999. Biologically mediated dissolution of calcium carbonate above the chemical lysocline? Deep Sea Research Part I: Oceanographic Research Papers, 46:1653-1699.

MOHTADI, M., D. W. OPPO, A. LCKGE, R. DEPOL34HOLZ, S. STEINKE, J. GROENEVELD, N. HEMME, AND D. HEBBELN. 2011. Reconstructing the thermal structure of the upper ocean: Insights from modern planktonic foraminifera shells chemistry and alkenones in modern sediments of the tropical eastern Indian Ocean. Paleoceanography, 24, PA3219, doi:10.1029/2011PA002132.

MULITZA, S., D. BOLTOVSKOY, B. DONNER, H.
MEGGERS, A. PAUL, AND G. WEFER. 2003. Temperature: $\delta^{18} \mathrm{O}$ relationships of planktonic foraminifera collected from surface waters. Palaeogeography, Palaeoclimatology, Palaeoecology, 202:143-152.

MULITZA, S., B. DONNER, G. FISCHER, A. PAUL, J. PÄTZOLD, C. RÜHLEMANN, AND M. SEGL. 1999. The South Atlantic oxygen isotope record of planktic foraminifera, p. 121-142. In G. WEFER. S. Mulitza, AND V. RATMEYer (eds.). The South Atlantic in the Late Quaternary: Reconstruction of Material Budgets and Current Systems, SpringerVerlag, Berlin.

MULITZA, S., A. DÜRKOOP, W. HALE, G. WEFER, AND H. S. NIEBLER. 1997. Planktonic foraminifera as recorders of past surface-water stratification. Geology, 25:335-338.

NATIONAL RESEARCH COUNCIL. 2011. Scientific Ocean Drilling: Accomplishments and Challenges. National Academies Press, Washington DC, 145 p.

NIER, A. O. 1947. A mass spectrometer for isotopes and gas analysis. Review of Scientific Instruments, 18:398-411.

NORRIS, R. D., R. M. CORFIELD, AND J. E. CARTLIDGE. 1993. Evolution of depth ecology in the planktonic foraminifera lineage Globorotalia (Fohsella). Geology, 11:975-978.

NORRIS, R. D., R. M. CORFIELD, AND J. E. CARTLIDGE. 1996. What is gradualism? Cryptic speciation in globorotaliid foraminifera. Paleobiology, 22:386-405.

NORRIS, R. D., AND P. A. WILSON. 1998. Lowlatitude sea-surface temperatures for the midCretaceous and the evolution of planktic foraminifera. Geology, 26:823-826.

OLAUSSON, E. 1965. Evidence of climatic changes in North Atlantic deep-sea cores, with remarks on isotopic temperature analysis. Progress in Oceanography, 3:221-252.

OLAUSSON, E. 1996. The Swedish Deep-Sea Expedition with the "Albatross" 1947-1948: A Summary of Sediment Core Studies. Novum , Grafiska AB, Göteborg, 98 p.

O'NEIL, J. R., R. N. CLAYTON, AND T. K. MAYEDA. 1969. Oxygen isotope fractionation in divalent metal carbonates. Journal of Chemical Physics, 51:5547-5558.

PÄLIKE, H., J. FRAZIER, AND J. C. ZACHOS. 2006. Extended orbitally forced palaeoclimate records from the Atlantic Ceara Rise. Quaternary Science Reviews, 25:3138-3149.

PÄLIKE, H, J., L. LASKAR, AND N. J. SHACKLETON. 2004. Constraints on astronomical parameters from the geological record of the past $25 \mathrm{Ma}$. Earth and Planetary Science Letters, 182:1-14.

PEARSON, P. N. 1998. Stable isotope and the study of evolution in planktonic foraminifera. The Paleontological Society Papers, 4:138-178. 
PEARSON, P. N., AND C. E. BURGESS. 2008. Foraminifer test preservation and diagenesis: comparison of high latitude sites, p. 59-72. In W. E. N. Austin, AND R. H. JAMES (eds.). Biogeochemical Controls on Paleoceanographic Environmental Proxies, Geological Society of London, Special Publications, No. 303.

PEARSON, P. N., P. DITCHFIELD, AND N. J. SHACKLETON. 2002. Palaeoclimatology (Communications arising): Tropical temperatures in greenhouse climates. Nature, 419:898.

PEARSON, P. N., P. W. DITCHFIELD, J. SINGANO, K. G. HARCOURT-BROWN, C. J. NICHOLAS, R. K. OLSSON, N. J. SHACKLETON, AND M. A. HALL. 2001. Warm tropical sea surface temperatures in the Late Cretaceous and Eocene epochs. Nature, 413:481-487.

PEARSON, P. N., AND N. J. SHACKLETON. 1995. Neogene multispecies planktonic foraminifer stable isotope record, Site 871, Limalok guyot. Proceedings of the Ocean Drilling Program, Scientific Results, 144:21-59.

PEARSON, P. N., N. J. SHACKLETON, AND M. A. HALL. 1993. Stable isotope paleoecology of middle Eocene planktonic foraminifera and multispecies isotope stratigraphy, DSDP Site 523, South Atlantic. Journal of Foraminiferal Research, 23:123-140.

PEARSON, P. N., N. J. SHACKLETON, AND M. A. HALL. 1997. Stable isotopic evidence for the sympatric divergence of Globigerinoides trilobus and Orbulina universa (planktonic foraminifera). Journal of the Geological Society, 154:295-302.

PEARSON, P. N., B. E. VAN DONGEN, C. J. NICHOLAS, R. D. PANCOST, S. SCHOUTEN, J. M. SINGANO, AND B. S. WADE. 2007. Stable warm tropical climate through the Eocene epoch. Geology, 35:211-214.

PEARSON, P. N., AND WADE, B. S. 2009. Taxonomy and stable isotope paleoecology of well-preserved planktonic foraminifera from the uppermost Oligocene of Trinidad. Journal of Foraminiferal Research, 39:191-217.

PECK, V. L., J. YU, S. KENDER, AND C. R. RIESSELMAN. 2010. Shifting ocean carbonate chemistry during the Eocene-Oligocene climate transition: implications for deep ocean $\mathrm{Mg} / \mathrm{Ca}$ paleothermometry. Paleoceanography, 25, PA4219. doi:10.1029/2009PA001906.

PISIAS, N. G., D. G. MARTINSON, T. C. MOORE, N. J. SHACKLETON, W. PRELL, J. HAYS, AND G. BODEN. 1984. High resolution stratigraphic correlation of benthic oxygen isotopes spanning the last 300,000 years. Marine Geology, 56:119136.

POORE, R.Z., AND R. K. MATTHEWS. 1984. Oxygen isotope ranking of late Eocene and Oligocene planktonic foraminifers: implications for Oligo- cene sea surface temperatures and global ice volumes. Marine Micropaleontology, 9:111-134.

PROKOPH, A., G. A. SHIELDS, AND J. VEIZER. 2008. Compilation and time-series analysis of marine carbonate $\delta^{18} \mathrm{O}, \delta^{13} \mathrm{C},{ }^{87} \mathrm{Sr} /{ }^{86} \mathrm{Sr}$ and $\delta^{34} \mathrm{~S}$ database through Earth history. Earth Science Reviews, 87:113-133.

PURTON, L., AND M. D. BRASIER. 1999. Giant protist Nummulites and its Eocene environment: Life span and habitat insights from $\delta^{18} \mathrm{O}$ and $\delta^{13} \mathrm{C}$ data from Nummulites and Venericardia, Hampshire basin, UK. Geology, 27:711-714.

PUSZ, A. F., R. C. THUNELL, AND K. G. MILLER. 2011. Deep water temperature, carbonate ion, and ice volume changes across the Eocene-Oligocene climate transition. Paleoceanography, 26, PA2205. doi:10.1029/2010PA001950.

RASMUSSEN, T. L., AND E. THOMSEN. 2009. Stable isotope signals from brines in the Barents Sea: implications for brine formation during the last glaciation. Geology, 37:903-906.

RATHMANN, S., AND H. KUHNERT. 2008. Carbonate ion effect on $\mathrm{Mg} / \mathrm{Ca}, \mathrm{Sr} / \mathrm{Ca}$ and stable isotopes on the benthic foraminifera Oridorsalis umbonatus off Namibia. Marine Micropaleontology, 66:120133.

RAYMO, M. E., L. LISIECKI, AND K. NISANCIOGLU. 2006. Plio-Pleistocene ice volume, Antarctic climate, and the global $\delta^{18} \mathrm{O}$ record. Science, 313:492-495.

REICHART, G.-J., F. JORISSEN, P. ANSCHUTZ, AND P. R. D. MASON. 2003. Single foraminiferal test chemistry records the marine environment. Geology, 31:355-358.

RINK, S., M. KÜHL, J. BIJMA, AND H. SPERO. 1998. Microsensor studies of photosynthesis and respiration in the symbiotic foraminifer Orbulina universa. Marine Biology, 131:583-595.

ROBERTS, C. D., A. N. LEGRANDE, AND A. K. TRIPATI. 2011. Sensitivity of seawater oxygen isotopes to climatic and tectonic boundary conditions in an early Paleogene simulation with GISS Model E-R. Paleoceanography 26:PA 4203 , doi:10.1029/201pa002025.

RODHE, W. 1974. Plankton, planktis, planktonic. Limnology and Oceanography, 19:360.

ROHLING, E. J., AND S. COOKE. 1999. Stable oxygen and carbon isotopes in foraminiferal carbonate shells, p. 239-258. In B. SEN GUPTA (ed.). Modern Foraminifera. Kluwer, Dordrecht.

ROLLION-BARD, C., J. EREZ, AND T. ZILBERMAN. 2008. Intra-shell oxygen isotope ratios in the benthic foraminifera genus Amphistegina and the influence of seawater carbonate chemistry and temperature on this ratio. Geochimica et Cosmochimica Acta, 72:6006-6014.

ROSMAN, J. R., AND P. D. TAYLOR. 1998. Isotopic compositions of the elements (technical report): 
commission on atomic weights and isotopic abundances. Pure and Applied Chemistry, 70:217-235.

SAUTTER, L. R., AND R. C. THUNELL. 1991. Seasonal variability in $\delta^{18} \mathrm{O}$ and $\delta^{13} \mathrm{C}$ of planktonic foraminifera from an upwelling environment: sediment trap results from the San Pedro Basin, Southern California Bight. Paleoceanography, 6:307-334.

SAVIN, S. M. 1977. The history of Earth's surface temperature during the past 100 million years. Annual Reviews of Earth and Planetary Science, 5:319-355.

SAVIN, S. M., L. ABEL, E. BARRERA, D. A. HODELL, G. KELLER, J. P. KENNETT, J. KILLINGLEY, M. MURPHY, AND E. VINCENT. 1985. The evolution of Miocene surface and near-surface temperatures, oxygen isotopic evidence, p. 49-82. In J. P. KenNeTt (ed.). The Miocene Ocean: Paleoceanography and Biogeography. Geological Society of America, Memoir, No.163.

SAVIN, S. M., R. G. DOUGLAS, AND F. G. STEHLI. 1975. Tertiary marine paleotemperatures. Geological Society of America, Bulletin, 86:1499-1510.

SCHIEBEL, R. 2002. Planktonic foraminiferal sedimentation and the marine calcite budget. Global Biogeochemical Cycles, 11:125-133.

SCHIFFELBEIN, P., AND S. HILLS. 1984. Direct assessment of stable isotope variability in planktonic foraminifera populations. Palaeogeography, Palaeoclimatology, Palaeoecology, 48:197-213.

SCHMIDT, G. A. 1999. Forward modeling of carbonate proxy data from planktonic foraminifera using oxygen isotope tracers in a global ocean model. Paleoceanography, 14:482-497.

SCHMIDT, G. A., G. R. BIGG, AND E. J. ROHLING. 1999. Global seawater Oxygen-18 databasev1.21: http://data.giss.nasa.gov/o18data/

SCHNEIDER, C. E., AND J. P. KENNETT. 1996. Isotopic evidence for interspecies habitat differences during evolution of the Neogene planktonic foraminferal clade Globoconella. Paleobiology, 22:282-303.

SCHRAG, D. P. 1999. Effects of diagenesis on the isotopic record of late Paleogene tropical sea surface temperatures. Chemical Geology, 1999:215-224.

SCHRAG, D. P., J. F. ATKINS, K. MCINTYRE, J. L. ALEXANDER, D. A. HODELL, C. D. CHARLES, AND J. F. MCMANUS. 2002. The oxygen isotopic composition of seawater during the Last Glacial Maximum. Quaternary Science Reviews, 21:331-342.

SELF-TRAIL, J. M., AND E. L. SEEFELT. 2004. Rapid dissolution of calcareous nannofossils from freshly cored sediments, USA. Journal of Nannoplankton Research, 26:94.

SEXTON, P. F., P. A. WILSON, AND P. N. PEARSON. 2006. Microstructural and geochemical perspectives on planktic foraminiferal preservation:
'Glassy' versus 'Frosty'. Geochemistry, Geophysi c s, Ge os y s te m s, 7 : Q 12 P 19 , doi:10.1029/2006GC001291.

SHACKLETON, N. J. 1967. Oxygen isotope analyses and Pleistocene temperatures reassessed. Nature, 215:15-17.

SHACKLETON, N. J. 1974. Attainment of isotopic equilibrium between ocean water and the benthonic foraminifera genus Uvigerina, p. 203-209. In Isotopic changes in the ocean during the last glacial. Cent. Nat. Rech. Sci. Colloq. Int., No. 219.

SHACKLETON, N. J. 1986. Paleogene stable isotope events. Palaeogeography, Palaeoclimatology, $\mathrm{Pa}-$ laeoecology, 57:91-102.

SHACKLETON, N. J. 2000. The 100,000-year ice-age cycle identified and found to lag temperature, carbon dioxide, and orbital eccentricity. Science, 289:1897-1902.

SHACKLETON, N., AND A. BOERSMA. 1981. The climate of the Eocene ocean. Journal of the Geological Society of London, 138:153-157.

SHACKLETON, N. J., R. M. CORFIELD, AND M. A. HALL. 1985. Stable isotope data and the ontogeny of Paleocene planktonic foraminifera. Journal of Foraminiferal Research, 15:321-336.

SHACKLETON, N. J., S. J. CROWHURST, G. P. WEEDON, AND J. LASKAR. 1999. Astronomical calibration of Oligocene-Miocene time. Philosophical Transactions of the Royal Society of London, Series A, 357:1907-1929.

SHACKLETON, N. J., AND J. P. KENNETT. 1975. Paleotemperature history of the Cenozoic and the initiation of Antarctic glaciation: oxygen and carbon isotope analyses in DSDP Sites 277, 279, and 281. Initial Reports of the Deep Sea Drilling Project, 29:743-755.

SHACKLETON, N. J., AND N. D. OPDYKE. 1973. Oxygen isotope and palaeomagnetic stratigraphy of equatorial Pacific core V28-238: Oxygen isotope temperatures and ice volumes on a $10^{5}$ year and $10^{6}$ year scale. Quaternary Research, 3:39-55.

SHACKLETON, N. J., J. D. H. WISEMAN, AND H. A. BUCKLEY. 1973. Non-equilibrium isotopic fractionation between seawater and planktonic foraminiferal tests. Nature, 242:177-179.

SHIEH, Y.-T., C.-F. YOU, K.-S. SHEA, AND C.-S. HONG. 2002. Identification of artifacts in foraminiferal tests using carbon and oxygen isotopes: Journal of Asian Earth Sciences, 21:1-5.

SPERO, H. J. 1992. Do planktic foraminifera accurately record shifts in the carbon isotopic composition of sea water $\Sigma \mathrm{CO}_{2}$ ? Marine Micropaleontology, 19:275-285.

SPERO, H. J. 1998. Life history and stable isotope geochemistry of planktonic foraminifera. The Paleontological Society Papers, 4:7-36.

SPERO, H. J., J. BIJMA, D. W. LEA, AND B. E. BEMIS. 1997. Effect of seawater carbonate concen- 
tration on foraminiferal carbon and oxygen isotopes. Nature, 390:497-500.

SPERO, H. J., AND D. W. LEA. 1993. Intraspecific stable isotope variability in the planktic foraminifera Globigerinoides sacculifer: results from laboratory experiments. Marine Micropaleontology, 22:221234.

SPERO, H. J., K. M. MIELKE, E. M. KALVE, D. W. LEA, AND D. K. PAK. 2003. Multispecies approach to reconstructing eastern equatorial Pacific thermocline hydrography during the past $360 \mathrm{kyr}$. $\mathrm{P}$ a l e o c a n o g r a p h , 18 , doi:10.1029/2002PA000814.

STEWART, D. R. M., P. N. PEARSON, P. W. DITCHFIELD, AND J. M. SINGANO. 2004. Miocene ocean temperatures: evidence from three exceptionally preserved foraminiferal assemblages from Tanzania. Journal of African Earth Sciences, 40, 173-189.

STOTT, L. D., AND C. M. TANG. 1996. Reassessment of tropical sea surface $\delta^{18} \mathrm{O}$ temperatures. Paleoceanography, 11:37-56.

TANG, C. M., AND L. D. STOTT. 1993. Seasonal salinity changes during Mediterranean sapropel deposition 9,000 years B.P.: Evidence from isotopic analyses of individual planktonic foraminifera. Paleoceanography, 8:473-494.

TINDALL，J., R. FLECKER, P. VALDES, D. N. SCHMIDT, P. MARKWICK, AND J. HARRIS. 2010. Modelling the oxygen isotope distribution of ancient seawater using a coupled oceanatmosphere GCM: Implications for reconstructing early Eocene climate. Earth and Planetary Science Letters, 292:265-273.

UCHIKAWA, J., AND R. E. ZEEBE. 2010. Examining possible effects of seawater $\mathrm{pH}$ decline on foraminiferal stable isotopes during the Paleocene-Eocene thermal maximum. Paleoceanography, 25:PA2216, doi:10.1029/2009PA001864.

UJIIÉ, Y. AND J. H. LIPPS. 2009. Cryptic diversity in planktic foraminifera in the northwest Pacific Ocean. Journal of Foraminiferal Research, 39:145-154.

UREY, H. C. 1947. The thermodynamic properties of isotopic substances. Journal of the Chemical Society of London, 1947:562-581.

UREY, H. C. 1948. Oxygen isotopes in nature and in the laboratory. Science, 108:489-496.

UREY, H. C., H. LOWENSTHAM, S. EPSTEIN, AND C. R. MCKINNEY. 1951. Measurement of paleotemperatures of the Upper Cretaceous of England, Denmark and the south-eastern United States. Bulletin of the Geological Society of America, 62:399-426.

VEIZER, J., D. ALA, K. AZMY, P. BRUCKSCHEN, D. BUHL, F. BRUHN, G. A. F. CARDEN, A. DIENER, S. EBNETH, Y. GODDERIS, T. JASPER, C. KORTE, F. PAWELLEK, O. G. PODLAHA,
AND H. STRAUSS. 1999. ${ }^{87} \mathrm{Sr} /{ }^{86} \mathrm{Sr}, \delta^{13} \mathrm{C}$ and $\delta^{18} \mathrm{O}$ evolution of Phanerozoic seawater. Chemical Geology, 161:59-88.

VEIZER, J., P. BRUCKSCHEN, F. PAWELLEK, A. DIENER, G. PODLAHA, G.A.F. CARDEN, T. JASPER, C. KORTE, H. STRAUSS, K. AZMY, AND D. ALA. 1997. Oxygen isotope evolution of Phanerozoic seawater. Palaeogeography, Palaeoclimatology, Palaeoecology, 132:159-172.

VEIZER, J., Y. GODDERIS, AND L. M. FRANÇOIS. 2000. Evidence for decoupling of atmospheric $\mathrm{CO}_{2}$ and global climate during the Phanerozoic eon. Nature, 408:698-701.

VIDAL, L., L. LABEYRIE, AND T. C. E. VAN WEERING. 1998. Benthic $\delta^{18} \mathrm{O}$ records in the North Atlantic over the last glacial period (60-10 k.yr.): Evidence for brine formation. Paleoceanography, 13:245-251.

VINCENT, E., J. S. KILLINGLEY, AND W. H. BERGER. 1985. Miocene oxygen and carbon isotope stratigraphy of the tropical Indian Ocean. p. 103-130. In J. P. KennetT (ed.). The Miocene Ocean: Paleoceanography and Biogeography. Geological Society of America, Memoir, No.163.

WADE, B. S., J. P. HOUBEN, W. QUAIJTAAL, S. SCHOUTEN, Y. ROSENTHAL, K. G. MILLER, M. E. KATZ, J. D. WRIGHT, AND H. BRINKHUIS. 2012. Multiproxy record of abrupt sea-surface cooling across the Eocene-Oligocene transition in the Gulf of Mexico. Geology, 40:159162.

WADE, B. S., AND H. PÄLIKE. 2004. Oligocene climate dynamics. Paleoceanography, 19:PA4019, doi:10.1029/2004PA001042.

WADE, B. S., P. N. PEARSON, W. A. BERGGREN, AND H. PÄLIKE. 2011. Review and revision of Cenozoic tropical planktonic foraminiferal biostratigraphy and calibration to the geomagnetic polarity and astronomical timescale. Earth Science Reviews, 104:111-142.

WAELBROECK, C., S. MULITZA, H. SPERO, T. DOKKEN, T. KIEFER, AND E. CORTIJO. 2005. A global compilation of late Holocene planktonic foraminiferal $\delta^{18} \mathrm{O}$ : relationship between surface water temperature and $\delta^{18} \mathrm{O}$. Quaternary Science Reviews, 24:853-868.

WALLMANN, K. 2001. The geological water cycle and the evolution of marine $\delta^{18} \mathrm{O}$ values. Geochimica et Cosmochimica Acta, 65:2469-2485.

WANG, L. 2000. Isotopic signals in two morphotypes of Globigerinoides ruber (white) from the South China Sea: Implications for monsoon climate change during the last glacial cycle. Palaeogeography, Palaeoclimatology, Palaeoecology, 161:381-394.

WEFER, G., AND W. H. BERGER. 1991. Isotope paleontology: Growth and composition of extant calcareous species. Marine Geology, 100:207-248. 
WESTERHOLD, T., T. BICKERT, AND U. ROHL. 1995. Middle to late Miocene oxygen isotope stratigraphy of ODP site 1085 (SE Atlantic): new constraints on Miocene climate variability and sealevel fluctuations. Palaeogeography, Palaeoclimatology, Palaeoecology, 217:205-222.

WILLIAMS, D. F., A. W. H. BÉ, AND R. G. FAIRBANKS. 1981. Seasonal stable isotope variations in living planktonic foraminifera from Bermuda plankton tows. Palaeogeography, Palaeoclimatology, Palaeoecology, 33:71-102.

WILLIAMS, M., A. M. HAYWOOD, S. P. TAYLOR, P. J. VALDES, B. W. SELLWOOD, AND C.-D. HILLENBRAND. 2004. Evaluating the efficacy of planktonic forminifer calcite $\delta^{18} \mathrm{O}$ data for sea surface temperature reconstruction for the Late Miocene. Geobios, 38:843-863.

WILLIAMS, M., A. M. HAYWOOD, M. VAUTRAVERS, B. W. SELLWOOD, C.-D. HILLBRAND, I. P. A. WILKINSON, AND C. G. MILLER. 2007. Relative effect of taphonomy on calcification temperature estimates from fossil planktonic foraminifera. Geobios, 40:861-874.

WILSON, D. S., S. S. R. JAMIESON, P. J. BARRETT, G. LEITCHENKOV, K. GÖHL, AND R. D. LARTER. 2012. Antarctic topography at the Eocene-Oligocene boundary. Palaeogeography, Palaeoclimatology, Palaeoecology, 335-336:24-34.

WILSON, P. A., AND R. D. NORRIS. 2001. Warm tropical ocean surface and global anoxia during the mid-Cretaceous period. Nature, 412:425-429.

WILSON, P. A., R. D. NORRIS, AND M. J. COOPER. 2002. Testing the Cretaceous greenhouse hypothesis using glassy foraminiferal calcite from the core of the Turnoian tropics on Demerara Rise. Geology, 30:607-610.

WILSON, P. A., AND B. N. OPDYKE. 1996. Equatorial sea-surface temperatures for the Maastrichtian revealed through remarkable preservation of metastable carbonate. Geology, 24:555-558.

WILSON-FINELLI, A., G. T. CHANDLER, AND H. J. SPERO. 1998. Stable isotope behavior in paleoceanographically important benthic foraminifera; results from microcosm culture experiments. Journal of Foraminiferal Research, 28:312-320.

WINTERER, E. L. 2000. Scientific ocean drilling, from AMSOC to COMPOST, p. 117-127. In 50 years of Ocean Discovery, National Academy Press, Washington, DC.

ZACHOS, J. C., M. A. ARTHUR, T. J. BRALOWER, AND H. J. SPERO. 2002. Palaeoclimatology (Communication arising): tropical temperatures in greenhouse episodes. Nature, 419:897-898.

ZACHOS, J. C., S. M. BOHATY, C. M. JOHN, H. MCCARREN, D. C. KELLY, AND T. NIELSEN. 2007. The Palaeocene-Eocene carbon isotope excursion: constraints from individual shell planktonic foraminifer records. Philosophical Transac- tions of the Royal Society A, 365:1829-1842.

ZACHOS, J. C., J. R. BREZA, AND S. W. WISE. 1992. Early Oligocene ice sheet expansion on Antarctica: Stable isotope and sedimentological evidence from Kerguelen Plateau, southern Indian Ocean. Geology, 20:569-573.

ZACHOS, J. C., G. R. DICKENS, AND R. E. ZEEBE. 2008. An early Cenozoic perspective on greenhouse warming and carbon cycle dynamics. Nature, 451:279-283.

ZACHOS, J. C., M. PAGANI, L. SLOAN, E. THOMAS, AND K. BILLUPS. 2001. Trends, rhythms, and aberrations in global climate $65 \mathrm{Ma}$ to present. Science, 292:683-693.

ZACHOS, J. C., S. SCHOUTEN, S. BOHATY, T. QUATTLEBAUM, A. SLUIJS, H. BRINKHUIS, S. J. GIBBS, AND T. J. BRALOWER. 2006. Extreme warming of mid-latitude coastal ocean during the Paleocene-Eocene Thermal maximum: Inferences from TEX86 and isotopic data. Geology, 34:737-740.

ZACHOS, J. C., L. D. STOTT, AND K. C. LOHMANN. 1994. Evolution of early Cenozoic marine temperatures. Paleoceanography, 9:353-387.

ZEEBE, R. E. 1999. An explanation of the effect of seawater carbonate concentration on foraminiferal oxygen isotopes. Geochemica et Cosmochimica Acta, 63:2001-2007.

ZEEBE, R. E. 2001. Seawater $\mathrm{pH}$ and isotopic paleotemperatures of Cretaceous oceans. Palaeogeography, Palaeoclimatology, Palaeoecology, 170:4957.

ZEEBE, R. E. 2012. History of seawater carbonate chemistry, atmospheric $\mathrm{CO}_{2}$, and ocean acidification. Annual Reviews of Earth and Planetary Sciences, 40:141-165.

ZEEBE, R. E., J. BIJMA, B. HÖNISCH, A. SANYAL, H. J. SPERO, AND D. A. WOLF-GLADROW. 2008. Vital effects and beyond: a modelling perspective on developing paleoceanographical proxy relationships in foraminifera, p. 45-58. In W. E. N. Austin, AND R. H. JAMES (eds.). Biogeochemical Controls on Paleoceanographic Proxies. Geological Society of London, Special Publications, No. 303.

ZIVERI, P., S. THOMAS, I. PROBERT, M. GEISEN, AND G. LANGER. 2012. A universal carbonate ion effect on stable oxygen isotope ratios in unicellular planktonic calcifying organisms. Biogeosciences, 9:1025-1032. 